
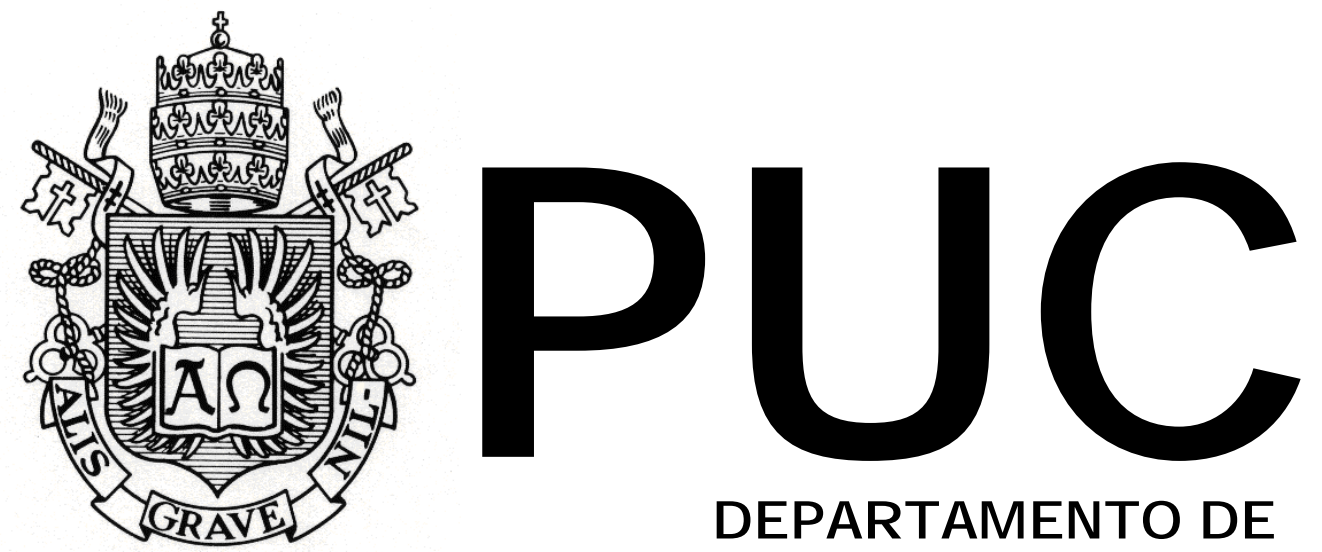

DEPARTAMENTO DE DIREITO

\title{
MEDO, TERRORISMO E DIREITOS HUMANOS
}

por

CINTIA RESCHKE DE BORBA

ORIENTADOR: João Ricardo w. Dornelles 2009.1

PONTIFÍCIA UNIVERSIDADE CATÓLICA DO RIO DE JANEIRO

RUA MARQUÊS DE SÃO VICENTE, 225 - CEP 22453-900

RIO DE JANEIRO - BRASIL 


\title{
MEDO, TERRORISMO E DIREITOS HUMANOS
}

\author{
por
}

\section{CINTIA RESCHKE DE BORBA}

Monografia apresentada ao Departamento de Direito da Pontifícia Universidade Católica do Rio de Janeiro (PUC-Rio) para a obtenção do Título de Bacharel em Direito.

Orientador: João Ricardo W. Dornelles 


\section{AGRADECIMENTOS}

Ao querido professor João Ricardo W. Dornelles, meu orientador nesta monografia e na pesquisa de iniciação científica, pelas suas considerações sempre pertinentes, pela compreensão e estímulo em todos os momentos e, acima de tudo, por ter me apresentado ao estudo da criminologia e ter me convidado para participar do Observatório de Controle Social e Sistema Punitivo (do Núcleo de Direitos Humanos da PUC-Rio), no início de 2007, que foi fundamental na minha formação acadêmica e pessoal.

Ao professor Liszt Vieira, meu orientador no projeto de pesquisa Globalização, Soberania e Estado Nacional, pelo constante e rico aprendizado, pelas profícuas discussões e pela amizade.

À minha família: Minha mãe, Heliete; meu pai, Carlos Alberto; minhas irmãs, Cibele e Catlyn; meus avós, Neusa, Élio, Ilza (in memoriam) e Carlos (in memoriam); meus tios, Lia, Luiz e Paulo; e meu primos, Laís e Daniel, obrigada por vocês fazerem parte da minha vida.

To Tom, for all the love and support.

A Deus, pelo dom da vida e por ter me permitido chegar até aqui. 


\section{Is it True? ${ }^{1}$}

Is it true that the grass grows again after rain? Is it true that the flowers will rise up again in the Spring?

Is it true that birds will migrate home again?

Is it true that the salmon swim back up their streams?

It is true. This is true. These are all miracles. But is it true that one day we'll leave Guantánamo Bay?

Is it true that one day we'll go back to our homes?

I sail in my dreams. I am dreaming of home.

To be with my children, each one part of me;

To be with my wife and the ones that I love;

To be with my parents, my world's tenderest hearts.

I dream to be home, to be free from this cage.

But do you hear me, oh Judge, do you hear me at all?

We are innocent, here, we've committed no crime.

Set me free, set us free, if anywhere still

Justice and compassion remain in this world!

\section{Usama Hassan Ahmed Abu Abir}

Jordaniano, prisioneiro em Guantánamo, capturado no Afeganistão em novembro de 2001 e

$$
\text { libertado na Jordania em novembro de } 2007 .
$$

${ }^{1}$ Poema do I'

Poems from Guantánamo: The Detainees $S p$ coletânea de poemas feitos pelos detentos de Guantána editados por Marc Falkc publicados em 2007 pela University of lowa Press. 


\section{RESUMO}

A presente monografia se propõe a realizar um estudo sobre medo, controle social, guerra ao terrorismo e o verdadeiro estado de exceção estabelecido pelas prisões de Guantánamo, Abu Ghraib e Bagram. Na primeira parte, faz-se uma análise das origens e formas do medo e como ele é manipulado e perpetuado com propósitos econômicos e políticos na sociedade pós-moderna. Num segundo momento, dedica-se ao estudo da figura de um inimigo interno específico muito atual: o terrorista e como a "guerra ao terrorismo", declarada após os eventos ocorridos em 11 de setembro, liderada pelos Estados Unidos, vem suprimindo liberdades e violando direitos humanos, por meio das novas legislações antiterroristas, das intervenções militares e do encarceramento de "suspeitos". Ainda neste capítulo, trabalha-se a brevemente política externa dos EUA, contemplando a sua "lógica imperialista". Por fim, discute-se como a prisão de Guantánamo representa um verdadeiro estado de exceção, em que "suspeitos" da prática de atos terroristas são mantidos por anos sem julgamento e privados de todas as garantias fundamentais, constituindo-se numa verdadeira aberração ética e jurídica.

Palavras chaves: medo; controle social; terrorismo; política externa norte-americana; ordem neoliberal; 11 de setembro; "guerra ao terror"; direitos humanos; Guantánamo; estado de exceção. 


\section{SUMÁRIO}

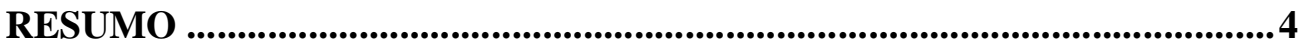

INTRODUÇÃ

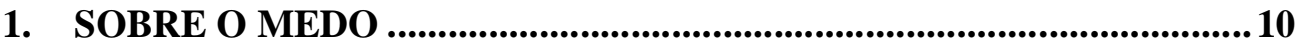

$1.1 \mathrm{O}$ Medo da Morte …................................................................................... 11

1.2 Causas, Facetas e Repercussões do Medo na Sociedade Pós-Moderna ..... 14

2. “GUERRA AO TERRORISMO” ...........................................................21

2.1 Conceituando Terrorismo e Terrorista...................................................... 22

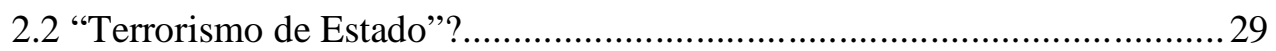

2.3 Alguns Comentários Acerca da Política Externa Norte-Americana ...........43

3. A PRISÃO DE GUANTÁNAMO ...........................................................4 49

3.1 A Origem da Prisão de Guantánamo ...................................................... 49

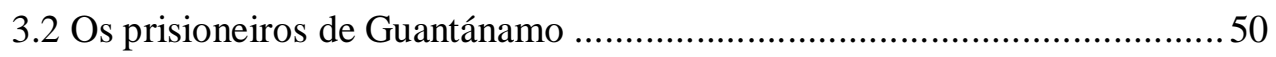

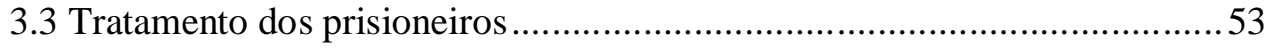

3.4 As Comissões Militares .................................................................... 61

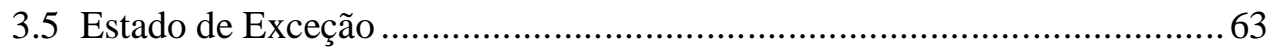

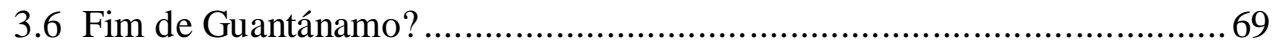

CONCLUSÃO

BIBLIOGRAFIA …......................................................................................... 75

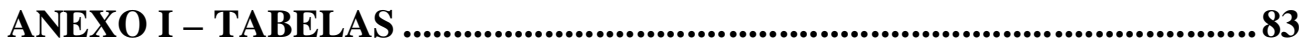




\section{ANEXO I - TABELAS}

\section{Tabela 01}

Prisioneiros transferidos da Prisão de Guantánamo (Cuba) para outros países

(Até 01 de Junho de 2009).

\section{Tabela 02}

Prisioneiros remanescentes na Prisão de Guantánamo (Cuba)

(Até 01 de Junho de 2009).

\section{Tabela 03}

Prisioneiros mortos na prisão de Guantánamo (2002 até 01 de junho de 2009). 


\section{INTRODUÇÃO}

A vida contemporânea é marcada pelo medo. As pessoas vivem constantemente assombradas pela sensação de insegurança e pelo temor de que algum mal as possa atingir a qualquer momento. Os meios de comunicação de massa bombardeiam o público diariamente com novos tipos de perigos e a idéia de que todos os indivíduos são vulneráveis. O medo é um mecanismo de dominação de grande potencial, que é largamente aproveitado por agentes políticos e econômicos para estimular o consumo e possibilitar a adoção de políticas e medidas, que dificilmente seriam aceitas ou viáveis, caso a população não estivesse paralisada pelo medo e ocupada o bastante na infindável tarefa de lidar com ele.

Neste sentido, um dos objetivos do presente trabalho é estudar o fenômeno do medo e como ele constitui um mecanismo de controle social amplamente utilizado pelos poderes dominantes, com vias a alcançar seus interesses e dar continuidade ao sistema capitalista vigente.

Outro foco desta pesquisa é o terrorismo, tópico tão em voga hoje em dia, e cujo significado e abrangência se pretende compreender melhor. Além disso, faz-se, uma breve análise da "guerra ao terror", decretada pelos Estados Unidos após os atentados de 11 de setembro de 2001 - que tem como pano de fundo a lógica da "guerra infinita"1 -, levando-se em conta os reais motivos que estão por trás dela, que dizem respeito, não à efetiva ameaça oferecida pelos ditos "terroristas", mas ao interesse em se dar continuidade à supremacia das forças dominantes e à ordem neoliberal.

\footnotetext{
${ }^{1}$ DORNELLES, João Ricardo W. Guerra Imperial Permanente versus Direitos Humanos. Artigo apresentado no Seminário "Direitos Humanos - Viena + 10 - Desafios e Perspectivas". Núcleo de Direitos Humanos da PUC-Rio, out. 2003. p. 1.
} 
Por fim, faz-se uma abordagem de como foi possível a apreensão e encarceramento de inocentes e o tratamento atroz que lhes é conferido em prisões como a de Abu Ghraib (no Iraque), a de Bagram (no Afeganistão) e, em particular, a de Guantánamo (em Cuba), utilizadas durante as guerras do Afeganistão e do Iraque. Embora uma análise mais aprofundada das prisões de Abu Ghraib e de Bagram fosse relevante, optou-se por direcionar o enfoque para Guantánamo para fins desta monografia. A intenção é estudar como a sua implantação foi viável em pleno século XXI, após tantas conquistas em matéria de direitos humanos nas últimas décadas.

A escolha do tema foi motivada pela sua extrema relevância nos dias atuais, haja vista a grande repercussão que tiveram as guerras do Afeganistão e do Iraque, assim como os abusos cometidos nas prisões em questão e a recente discussão acerca do possível fechamento de Guantánamo.

Diante da vasta bibliografia existente acerca dos temas mencionados, especialmente em termos de medo e controle social, foram utilizadas várias obras que foram importantes para a pesquisa, tendo-se optado, no entanto, por alguns autores específicos, considerados mais relevantes, para servir de base para o estudo.

O enfoque do primeiro capítulo foi o medo e suas repercussões na sociedade contemporânea, utilizando-se como base a obra Medo Líquido do renomado sociólogo polonês Zygmunt Bauman.

No segundo capítulo, que trata do terrorismo e da "guerra ao terror", serviram como base os trabalhos Conflito e Segurança: Entre pombos e falcões e Guerra Imperial Permanente versus Direitos Humanos, do professor João Ricardo W. Dornelles; 11 de setembro e Império americano: hegemonia ou sobrevivência, de Noam Chomsky, professor de lingüística do MIT (Massachusetts Institute of Technology) e ativista político; e Terrorism redefined: terrorism as "counter-hegemonic political 
violence", de Thomas Butko, professor do Departamento de Ciência Política da Universidade de Alberta, no Canadá.

No último capítulo, dedicado à análise da prisão de Guantánamo, foram de grande relevância, para a parte sobre estado de exceção, as obras Estado de Exceção - Homo Sacer II e Homo Sacer - O Poder Soberano e a Vida Nua I do filósofo italiano Giorgio Agamben, assim como o artigo Soberania imperial, espaços de exceção e o campo de Guantánamo: desterritorialização e confinamento na "guerra contra o terror", do professor do Instituto de Relações Internacionais da PUC-Rio, José María Gómez.

No tocante aos outros aspectos do estudo de Guantánamo, visto tratar-se de um capítulo recente da história e que ainda está em desenvolvimento, não há, até o momento, muita bibliografia a respeito, de modo que foram utilizadas notícias de fontes conhecidas, sobre o assunto, bem como relatórios da Anistia Internacional, da Human Rights Watch e do Center for Constitutional Rights, conceituadas organizações de direitos humanos; e um estudo detalhado sobre Guantánamo realizado pelo Centro de Direitos Humanos da University of California, Berkeley.

Vale ressaltar, ainda, que de forma alguma se tem a pretensão de exaurir os temas tratados, haja vista a sua complexidade e as inúmeras outras abordagens que poderiam ser feitas. O objetivo é desenvolver alguns aspectos considerados proeminentes, também por terem alguma conexão com a linha de pesquisa da autora desta monografia, no âmbito de seu projeto de iniciação científica. 


\section{SOBRE O MEDO}

"O medo é uma pressa que vem de todos os lados, uma pressa sem caminho".

Guimarães Rosa

O medo é um sentimento que acompanha o ser humano durante toda a sua vida. Segundo Zygmunt Bauman, a sua causa maior é a morte, podendo ser classificado em medo original e secundário.

O medo original traduz-se na sensação gerada quando se está diante de uma ameaça à vida, também compreendido como instinto de sobrevivência, que leva à fuga ou à agressão. Tal sentimento é compartilhado com todos os outros animais. Por outro lado, o medo secundário é particular ao ser humano e pode ser definido como o medo provocado pela consciência de que a morte é inevitável e pode chegar a qualquer tempo. Não é necessário que haja uma ameaça concreta, manifestando-se

\footnotetext{
"quer haja ou não uma ameaça presente. O medo secundário pode ser visto como um rastro de uma experiência passada de enfrentamento da ameaça direta - um resquício que sobrevive ao encontro e se torna um fator importante na modelagem da conduta humana mesmo que não haja mais uma ameaça direta à vida ou à integridade". ${ }^{2}$

Este "medo derivado", como o denomina Hughes Lagrange ${ }^{3}$, possuiria natureza social e consistiria na insegurança impulsionada pelo conhecimento da suscetibilidade e vulnerabilidade humanas frente $\mathrm{o}$
} perigo ${ }^{4}$.

\footnotetext{
${ }^{2}$ BAUMAN, Zygmunt. Medo Líquido. Rio de Janeiro: Jorge Zahar Editor, 2008. p. 9.

${ }^{3}$ Citado por Bauman. Ibid. p. 9.

${ }^{4}$ Ibid. p. 9.
} 


\subsection{O Medo da Morte}

Bauman afirma que o medo primitivo da morte "talvez seja o protótipo ou arquétipo de todos os medos - o medo definitivo de que todos os outros extraem seu significado". 5

Segundo o autor, a sociedade constrói mecanismos para tornar tolerável a existência com o medo da morte. E vai além, declarando que "todas as culturas humanas podem ser decodificadas como mecanismos engenhosos calculados para tornar suportável a vida com a consciência da morte."

Há uma vasta gama de mecanismos utilizados na tentativa de amenizar o medo da morte, que podem, entretanto, ser agrupados em três categorias principais. A estratégia mais empregada seria a negação da morte como o fim de tudo, constituindo apenas uma passagem deste mundo a outro. Diversas religiões e crenças surgiram defendendo a eternidade da alma e a continuidade da vida após a morte corpórea. O que, segundo Bauman, teria dotado a vida terrena de grande significado e importância, na medida em que, para alcançar a vida eterna, seria necessário viver de forma pura e zelosa. ${ }^{7}$

Outra tática consiste em se buscar a imortalidade pela memória, através da conquista de uma individualidade, um destaque na multidão. A principal forma de se conseguir a tão cobiçada individualidade é a fama individual, coletiva ou por meio de categorias -, a qual pressupõe esforços contínuos para alcançá-la e mantê-la.

\footnotetext{
${ }^{5}$ Ibid. p. 73.

${ }^{6}$ Ibid. p. 46.

${ }^{7}$ Ibid. p. 46-50.
} 
Aos indivíduos que não têm acesso à imortalidade individual, são dadas possibilidades de imortalidade despersonalizada, como a que Bauman chama de “imortalidade-por-procuração". 8 Esta, diversamente da imortalidade personalizada, não demanda a prática de atos memoráveis, mas é proporcionada como "prêmio de consolação" às pessoas que não têm esperança de realizar feitos importantes. Diante da sua inaptidão para obter a imortalidade por meio da vida, fazem-no por meio da morte. É a morte por uma causa que lhes confere tal espécie de imortalidade. Esta concepção foi bastante aproveitada por governantes na época da formação dos Estados-nação e da República francesa pós-revolucionária, que necessitavam de cidadãos patriotas prontos, se necessário, a sacrificar suas vidas em prol da imortalidade da nação. ${ }^{9}$

Com o gradual enfraquecimento do poder de convencimento da estratégia acima, ganha força, na sociedade contemporânea, o estratagema da marginalização das preocupações com a morte. Esta se opera por meio da desvalorização das coisas que são duráveis e de longo prazo, afastando a preocupação com a eternidade e a imortalidade.

Pode-se chegar a isso de duas maneiras: pela desconstrução e pela banalização da morte. Com relação à desconstrução, Bauman faz referência a Freud, que observou que os seres humanos tendem a empreender esforços para eliminar a morte da vida e a enfatizar as causas aleatórias a provocam, como acidentes e doenças, ocultando o seu aspecto necessário e natural ${ }^{10}$. Esta desconstrução está em sintonia com a proposta moderna de desintegrar o desafio existencial em vários problemas distintos que devem ser solucionados separadamente. Até então, acreditava-se ser finita a

\footnotetext{
${ }^{8}$ Ibid. p. 52.

${ }^{9}$ Ibid. p. 53.

${ }^{10}$ Ibid. p. 56.
} 
quantidade dos problemas existentes - e os que ainda estavam por vir - e ser possível prevê-los e dominá-los.

Todavia, a desconstrução, que se propunha a afastar a preocupação com a morte, surte efeito exatamente contrário. Intensifica ainda mais o pavor da morte e mantém-no presente e atuante em nossa vida diariamente de maneira que

\begin{abstract}
“da ameaça da morte não há agora um só momento de descanso. A luta contra a morte começa no nascimento e continua presente pela vida afora. Enquanto prossegue, é pontilhada por vitórias - ainda que a última batalha esteja fadada à derrota. Antes dela, contudo (e quem sabe antecipadamente que batalha se revelará como a última?), a morte permanece velada. Fragmentada em incontáveis preocupações com incontáveis ameaças, o medo da morte satura a totalidade da vida, embora na forma diluída de uma toxidade um tanto reduzida. Graças à ubiqüidade de suas pequenas doses, é improvável que o pavor da morte seja 'ingerido' totalmente e confrontado em toda a sua medonha horripilância, sendo suficientemente comum para poder paralisar o desejo de viver."11
\end{abstract}

Enquanto a desconstrução visa afastar o confronto com morte, decompondo-a em diversos problemas solucionáveis, a banalização pretende transformar o próprio enfrentamento em um evento trivial, por meio da realização de encenações diárias da morte.

Há várias formas de se experimentar a morte em vida, uma delas seria a morte de alguém próximo, que traz profundo sentimento de perda e que nos aproximaria da irreversibilidade e da finitude, permitindo-nos antever o significado da nossa própria morte. É o que Bauman denomina de "morte de segundo grau" e tratar-se-ia da "única modalidade em que a experiência da morte é acessível aos vivos". ${ }^{12}$

O que nos propicia ter essa "revelação" sobre a morte é justamente a perda de uma pessoa querida que nunca poderá ser completamente substituída em nossa vida. É o fim irreversível do "compartilhamento de um

\footnotetext{
${ }^{11}$ Ibid. p. 59.

${ }^{12}$ Ibid. p. 62.
} 
mundo" com esta pessoa. Um fim similar a este pode ser impulsionado por outros acontecimentos, que não a morte física do outro indivíduo, tais como o rompimento dos vínculos afetivos, causado pelo término de um namoro ou casamento, a que Bauman dá o nome de "morte de terceiro grau". 13

Assim, ocorre a banalização mediante a repetição do rompimento dos vínculos humanos, o que se dá quando estes se tornam frágeis. Bauman destaca que vivemos em tempos de fugacidade e fluidez. A sociedade "líquido-moderna", como ele a chama, caracteriza-se pela extrema superficialidade e curta duração das relações humanas, transformando a vida em um verdadeiro "ensaio diário da morte". ${ }^{14}$

O término de uma relação pode ocorrer por consentimento mútuo, mas geralmente o é por causa ou iniciativa de apenas uma das partes, separando-as em "vítima” e "ofensor". O rompimento do vínculo é sempre encarado pela "vítima" como rejeição e exclusão. Isso leva a crer que, na verdade, o medo da "morte de terceiro grau" representa o medo de ser excluído. O que implica, numa realidade fluida como a atual, repleta de mortes metafóricas, a necessidade de desconfiança e vigilância ininterruptas.

\subsection{Causas, Facetas e Repercussões do Medo na Sociedade Pós- Moderna}

\footnotetext{
Bauman explica que os perigos traduzem-se em

“'ameaças' e derivam seu poder de amedrontar do metaperigo da morte - embora sejam diferentes do original por serem evitáveis e talvez passíveis de serem prevenidos ou mesmo adiados indefinidamente. Ou pelo menos é o que se pode
}

\footnotetext{
${ }^{13}$ Ibid. p. $62-63$.

${ }^{14}$ Ibid. p. 63.
} 
esperar, mesmo que tais esperanças se frustrem mais freqüentemente do que são corroboradas e sustentadas." 15

Segundo o autor, há três categorias de perigos: os que ameaçam o corpo e as propriedades; os que incidem sobre a estabilidade da ordem social (que assegura o emprego e, portanto, o sustento); e os que recaem sobre a posição da pessoa no mundo e na sociedade (classe social e identidade - étnica, religiosa, etc.) e sobre a proteção contra a exclusão social $^{16}$.

Há, ainda, uma "terceira zona" de ameaças, concomitantemente humanas e naturais. Trata-se da zona nebulosa e não muito bem definida em que tragédias completamente inesperadas acontecem - como o esgotamento das jazidas de petróleo, o desaparecimento de grandes companhias (e dos serviços essenciais que prestam) e a queda de aviões com a morte dos passageiros. A cada dia ficamos sabendo de novos perigos que surgem e que podem nos assolar a qualquer momento. ${ }^{17}$

Interessante notar que os medos estão em todo o lugar e podem brotar

"de qualquer canto ou fresta de nossos lares e de nosso planeta. Das ruas escuras ou das telas luminosas dos televisores. De nossos quartos e de nossas cozinhas. De nossos locais de trabalho e do metrô que tomamos para ir e para voltar. De pessoas que encontramos e de pessoas que não conseguimos perceber. De algo que ingerimos e de algo com o qual nossos corpos entraram em contato. Do que chamamos 'natureza' (pronta, como dificilmente antes em nossa memória, a devastar nossos lares e empregos e ameaçando destruir nossos corpos com a proliferação de terremotos, inundações, furacões, deslizamentos, secas e ondas de calor) ou de outras pessoas (prontas, como dificilmente antes em nossa memória, a devastar nossos lares e empregos e ameaçando destruir nossos corpos com a súbita abundância de atrocidades terroristas, crimes violentos, agressões sexuais, comida envenenada, água ou ar poluídos)" ${ }^{18}$

\footnotetext{
${ }^{15}$ Ibid. p. 73.

${ }^{16}$ Ibid. p. 10.

${ }^{17}$ Ibid. p. 11.

${ }^{18}$ Ibid. p. 11.
} 
Isso tudo gera um sentimento de insegurança, com o qual somos obrigados a conviver diariamente. Sempre aparecem novos medos, as fontes nunca se esgotam. Quando se esvanecem alguns, aparecem outros. Essa autopropulsão é uma característica do medo. As causam que lhe dão ensejo se renovam e perpetuam-se automaticamente.

Deste modo, a sociedade líquido-moderna tem por objetivo reprimir esses temores produzidos cotidianamente e silenciar os medos originados por riscos que não podem ser evitados (ou não devem, em prol da preservação da ordem social). Essa repressão é realizada de maneira discreta e sutil, por meio do que Thomas Mathiesen, mencionado por Bauman, denominou de "silenciamento silencioso". ${ }^{19}$ Tal mecanismo é estrutural - não podendo, portanto, ser imputado ao Estado -, contínuo e habitual, o que o torna abrangente e eficaz. Além disso, atua de modo dinâmico e silencioso, o que lhe confere confiabilidade e legitimidade. ${ }^{20}$

Os medos são condizentes com a realidade líquido-moderna, pois nascem e diluem-se com facilidade e em ritmo acelerado, como pondera o autor: "os pânicos vêm e vão, e embora possam ser assustadores, é seguro presumir que terão o mesmo destino de todos os outros."21

Outra particularidade dos medos atuais é que eles são facilmente destacados de suas causas originais nas mentes dos sofredores de modo que as ações tomadas em resposta ao medo podem se dirigir para outras direções, que não as causas reais do sentimento de insegurança ${ }^{22}$.

\footnotetext{
${ }^{19}$ Ibid. p. 13.

${ }^{20}$ Ibid. p. 13.

${ }^{21}$ Ibid. p. 14.

${ }^{22}$ Ibid. p. 10 e 174.
} 
A maioria das tragédias anunciadas acaba não acontecendo e muitos dos medos chegam até as pessoas juntamente com os seus próprios remédios, como foi caso do bug do milênio, por exemplo, cujo risco foi anunciado pelas mesmas empresas que vendiam programas e ofereciam assessoria para lidar com o problema. Bauman alerta que esta prática pode ser vista como padrão para inúmeras outras situações, abastecendo a economia de consumo, ávida por consumidores. Pessoas aterrorizadas são presas fáceis para o mercado de produtos e artefatos que prometem propiciar-lhes proteção ${ }^{23}$.

Bauman ressalta que o que é mais estarrecedor não é o medo das tragédias em si e dos danos que elas podem acarretar, mas o sentimento de impotência motivado pela consciência de que não podemos prever os novos perigos que nascem constantemente e, por isso, nunca estaremos suficientemente prevenidos e as nossas defesas jamais serão fortes $\mathrm{o}$ bastante para derrotá-los.

Assim, passamos a ser escravos do medo e da insegurança, mesmo sem saber ao certo, por vezes, o que tememos ou porque estamos inseguros. A mídia e outros formadores de opinião desempenham papel fundamental neste processo, na medida em que bombardeiam o público com novos perigos e riscos e que vendem a idéia de que somos invariavelmente indefesos e vulneráveis (oferecendo, em muitos casos, como já dito, os possíveis artefatos para contê-los, mediante, é claro, a devida remuneração). ${ }^{24}$

Verifica-se, desta maneira, um contexto caótico, em que os indivíduos da era líquido-moderna passam suas vidas inteiras assombrados pelo medo e pela insegurança, agravados pelo sentimento de impotência perante os riscos que provocam estes medos. Conseqüentemente,

\footnotetext{
${ }^{23}$ Ibid. p. 15.

${ }^{24}$ Ibid. p. 15.
} 
consomem cada vez mais toda a sorte de produtos (em especial os da indústria de proteção pessoal e segurança), muitos deles supérfluos e em quantidades maiores do que seria necessário para viver, na tentativa de cessar os medos e suas causas e de remediar a frustração. Como tais artigos de consumo não funcionam - ou apenas surtem efeito temporário e paliativo -, vez que não se destinam a solucionar as verdadeiras origens das aflições, acabam por ocasionar ainda mais medo e angústia, o que leva a mais consumismo para sanar essas novas angústias que vão surgindo, gerando um perigoso e explosivo ciclo vicioso.

Neste sentido, na conjuntura pós-moderna, a guerra contra os medos perdura por toda a vida, muito diferente do que sonharam e difundiram os iluministas, que desejavam criar uma vida em que as paixões, os medos e as ameaças seriam dominados. O autor acrescenta que

"a vida inteira é agora uma longa luta, e provavelmente impossível de vencer, contra o impacto potencialmente incapacitante dos medos e contra os perigos, genuínos ou supostos, que nos tornam temerosos. Pode-se percebê-la melhor como uma busca contínua e uma perpétua checagem de estratagemas e expedientes que nos permitem afastar, mesmo que temporariamente, a iminência dos perigos - ou, melhor ainda, deslocar a preocupação com eles para o incinerador lateral onde possam, ao que se espera, fenecer ou permanecer esquecidos durante nossa duração. A inventividade humana não conhece fronteiras. Há uma plenitude de estratagemas. Quanto mais exuberantes são, mais eficazes e conclusivos os seus resultados. Embora, apesar de todas as diferenças que os separam, eles tenham um preceito comum: burlar o tempo e derrotá-lo no seu próprio campo. Retardar a frustração, não a satisfação." ${ }^{25}$

Outra estratégia na tentativa de contornar os medos e as incertezas do futuro é o imediatismo e o ímpeto de aproveitar o presente. Já que o futuro e os perigos são imprevisíveis, a ordem é desfrutar tudo o que se pode agora e não se preocupar com o amanhã, pois este pode não chegar. A substituição das cadernetas de poupança pelos cartões de crédito situa-se dentro desta lógica. Consoante Bauman, nunca uma geração foi tão

${ }^{25}$ Ibid. p. 15. 
endividada quanto a atual ${ }^{26}$. O futuro está fora de alcance, mas o cartão de crédito tem o poder mágico de trazê-lo para o presente, propiciando consumir por antecipação algo que só será cobrado posteriormente. As cadernetas de poupança demandam certa previsibilidade e constância na sua valorização, diferentemente dos cartões de crédito, que permitem desfrutar agora benefícios futuros. Bauman resume bem a problemática ao afirmar que "se as cadernetas de poupança implicam a certeza do futuro, um futuro incerto exige cartões de crédito.",27

A construção do projeto moderno baseou-se na procura crescente por felicidade. Na sociedade líquido-moderna, cada indivíduo é treinado desde pequeno para buscar a felicidade individual utilizando-se de meios e esforços individuais. $^{28}$

Em consonância com a já mencionada lógica da constante vigilância e prevenção, encontra-se, também, a lógica do excluir para não ser excluído, na qual as pessoas, temendo a exclusão social ou pessoal, que, supostamente, pode ocorrer a qualquer momento, são, por vezes, "compelidas" a perseguirem o seu próprio êxito e a "salvarem a sua própria pele", mesmo que isto acarrete a exclusão ou o prejuízo do outro. Não necessariamente porque sejam "más" e queiram prejudicar os outros, mas porque as regras do jogo são essas. ${ }^{29}$

Bauman exemplifica a questão ao fazer alusão aos reality shows, explicando que fazem tanto sucesso porque, com a sua sistemática de eliminação, simulam, na realidade, o jogo da vida. No mais famoso de todos, o Big Brother (que, aliás, é bem diferente do original criado por George Orwell, cujo objetivo era manter os participantes em um regime

\footnotetext{
${ }^{26}$ Ibid. p. 16.

${ }^{27}$ Ibid. p. 17.

${ }^{28}$ Ibid. p. 68.

${ }^{29}$ Ibid. p. 30 e $37-39$.
} 
controlado e não mandá-los embora), uma coisa é certa: a eliminação é inevitável (a chance de escapar a ela é mínima) e independe dos méritos do participante. Só não se sabe ainda quando ela virá, cabendo tentar postergála ao máximo. O programa gira em torno da cota de expulsões a ser observada: deve ser eliminada, necessariamente, uma pessoa por semana. Para não ser excluídos, os participantes têm de excluir. Tal como no mundo real, não há como escapar às regras do jogo. Todos devem votar pela expulsão de alguém, e sem sentimento de culpa, já que isso é o que devemos fazer. "Você não pode errar quando vota pela expulsão de alguém. É só quando hesita e resiste ao jogo que você corre o risco de ficar ou ser posto fora dele. E a sua aversão a jogar o jogo da exclusão não impedirá os outros de lhe darem uma bola preta." 30

De tal modo, a vida pós-moderna se torna um verdadeiro campo de batalha, uma luta de todos contra todos, cada um defendendo o seu interesse, buscando a sua felicidade e precavendo-se de todas as maneiras possíveis e imagináveis contra os perigos que assombram a existência humana, como os que podem causar a morte física, a morte metafórica, a exclusão social, o fim da durabilidade da ordem social e uma interminável quantidade de outras ameaças.

\footnotetext{
${ }^{30}$ Ibid. p. 40.
} 


\title{
2. "GUERRA AO TERRORISMO"
}

\begin{abstract}
"If we wait for threats to fully materialize, we will have waited too long [...] We must take the battle to the enemy, disrupt his plans and confront the worst threats before they emerge. [...] The only path to safety is action. And this nation will act. [...] [E]ven weak states and closed groups could attain a catastrophic power to strike great nations. [...] America stands for more than the absence of war. [...] We have a great opportunity to extend a just peace by replacing poverty, repression and resentment around the world with hope of a better day. [...] America was attacked by a ruthless and resourceful enemy. [...] In defending the peace, we face a threat without precedent. [...] In our development aid, in our diplomatic educational assistance, the United States will promote moderation and tolerance and human rights [...] [T]he requirements of freedom apply fully to Africa and Latin America and the entire Islamic world."
\end{abstract}

George W. Bush na cerimônia de formatura da $204^{a}$ turma da West Point, a mais antiga academia militar do país, em $1^{\circ}$ de junho de 2002.

Os atentados de 11 de setembro de 2001 são tidos como os maiores ataques terroristas da história. Não é preciso mencionar a enorme repercussão que estes acontecimentos tiveram no mundo, também pelo fato de terem ocorrido no território da maior potência mundial, que desde o ano de $1812^{31}$ não sofria um ataque, ou mesmo uma ameaça. ${ }^{32}$

Tais eventos marcaram a história contemporânea, desbancando a afirmação de Francis Fukuyama de que teríamos chegado ao fim da história $^{33}$. Pode-se afirmar que os episódios daquela manhã de terça-feira

\footnotetext{
${ }^{31}$ Ano em que foi declarada a chamada "Segunda Guerra de Independência dos EUA" contra a Inglaterra. Em uma das ocasiões o exército inglês conseguiu chegar a Washington e incendiou edifícios públicos, obrigando o presidente, James Madison, a deixar a capital. CHOMSKY, Noam. 11 de setembro. Rio de Janeiro: Bertrand Brasil, 2005. p. 11.

${ }^{32}$ Chomsky aponta que algumas pessoas tentaram fazer uma analogia com Pearl Harbor, o que é incorreto, pois, em dezembro de 1941, foram bombardeadas as bases de duas colônias americanas e não o território americano (o Havaí era de fato uma colônia e não um território, apesar de, algumas vezes, os Estados Unidos terem se referido a ele como tal). CHOMSKY, Noam. 11 de setembro. p. 12.

${ }^{33}$ FUKUYAMA, Francis. The End of History? The National Interest, 1989. Disponível em < www.unc.edu/ rlstev/Text/Fukuyama\%20End\%20of\%20History.pdf>. Acesso em 24 mai. 2009.
} 
iniciaram uma nova era na política externa americana e no contexto internacional como um todo. Impulsionaram uma série de ações lideradas pelos Estados Unidos, no âmbito da "guerra ao terrorismo", decretada pelo governo Bush, com o objetivo de, supostamente, buscar e punir os responsáveis pelos ataques e de evitar que outros viessem a acontecer.

Para uma melhor abordagem da conjuntura da "guerra ao terror", faz-se necessário, primeiramente, compreender o que se entende por terrorismo.

\subsection{Conceituando Terrorismo e Terrorista}

O terrorismo não é um fenômeno novo. Segundo Charles A. Russell, seria possível afirmar, inclusive, que precede a história registrada ${ }^{34}$.

Não obstante, o tratamento do tema como matéria de Direito internacional é de origem recente. Um dos primeiros esforços neste sentido foi a Convenção para a Prevenção e Punição do Terrorismo, elaborada pela Liga das Nações em 1937 e que nunca entrou em vigor. ${ }^{35}$ Posteriormente, a Organização das Nações Unidas tomou iniciativas semelhantes de combate ao terrorismo por meio de tratados multilaterais e do trabalho de diversos de seus órgãos. ${ }^{36}$

Da mesma forma, os órgãos das organizações regionais têm se empenhado em tratar da questão, firmando acordos e convênios

\footnotetext{
${ }^{34}$ Citado pela Comissão Interamericana de Direitos Humanos. COMISIÓN INTERAMERICANA DE DERECHOS HUMANOS. Informe Sobre Terrorismo y Derechos Humanos. Washington: OEA, 2002. p. 17.

${ }^{35}$ Ibid. p. 17.

${ }^{36}$ Como exemplo, podemos citar o Convênio para Repressão do Apoderamento Ilícito de Aeronaves, de 16 de dezembro de 1970 (860 U.N.T.S. 105), e a Resolução da Assembléia Geral da ONU 3034 (XXVII) sobre medidas para prevenir o terrorismo internacional, de 19 de dezembro de 1972 (ONU GAOR, 2114ª sessão plenária). Ibid. p. 18.
} 
multilaterais, como o Conselho da Europa, a União Européia, a Organização para Segurança e Cooperação da Europa, a União Africana e a Organização dos Estados Americanos. ${ }^{37}$ No sistema interamericano, mais especificamente, as iniciativas mais relevantes foram a adoção da Convenção para Prevenir e Punir os Atos de Terrorismo Configurados em Delitos Contra as Pessoas e a Extorsão Conexa, Quando Tiverem Eles Transcendência Internacional, de 2 de fevereiro de 1971, e da Convenção Interamericana Contra o Terrorismo, de 3 de junho de 2002, além da criação do Comitê Interamericano contra o Terrorismo (CICTE), em 1998.

Após os atentados de 11 de setembro, a luta contra o terrorismo adquiriu uma dimensão nunca antes imaginada, passando a desempenhar papel de extrema relevância e visibilidade na política externa dos Estados. No âmbito do Conselho de Segurança da ONU, foi adotada a Resolução 1373, em 28 de Setembro de 2001, condenando os atos terroristas, fazendo um apelo para o aumento da cooperação internacional nesta área e criando o Comitê Anti-Terrorismo, com a finalidade de monitorar o cumprimento da Resolução e de todas as convenções e protocolos sobre o assunto firmados desde 1963.

A despeito de todos os documentos já elaborados até hoje, não há um consenso no Direito internacional sobre o conceito de terrorismo. ${ }^{38}$

Aline Rabello, em sua dissertação de mestrado, atenta para o fato de que, desde que o termo foi incluído em dicionário pela primeira vez, há mais de dois séculos, teve inúmeros significados e usos diferentes. Ao citar Walter Laqueur, afirma ser impossível englobar todas as espécies de terrorismo que surgiram na história em apenas uma definição. ${ }^{39}$

\footnotetext{
${ }^{37}$ Ibid. p. 18.

${ }^{38}$ Ibid. p. 21.

${ }^{39}$ RABELO, Aline Louro de Souza e Silva. O conceito do terrorismo nos jornais americanos: uma análise do New York Times e do Washington Post logo após os atentados de 11 de setembro.
} 
Várias já foram as tentativas de se estabelecer uma definição completa que fosse aceita por todos na comunidade internacional, todas, no entanto, sem sucesso.

Os atentados ocorridos no mês de julho de 2005, incluindo os de Londres, levaram Kofi Annan ${ }^{40}$ a pedir urgência aos 192 países-membros da ONU na definição do termo terrorismo, uma questão há muito adiada. Segundo o ex-secretário-geral da ONU,

"o que ocorreu nas últimas semanas em Londres e Sharm el-Sheikh nos dá uma razão a mais para avançar e conseguir uma boa definição de terrorismo, uma com a qual todos possamos viver. [...] Creio que todo o mundo está hoje unido na luta contra o terrorismo." ${ }^{41}$

A demora na solução do impasse, em parte justificada por se tratar de um assunto politicamente delicado, restringe novas ações para lidar com o problema no cenário internacional. A elaboração do texto da convenção número 13 contra o terrorismo está paralisada desde 2002, essencialmente pela falta de acordo entre os diversos países sobre o que realmente significa o termo. A sua redação compreende a maior parte das disposições constantes das 12 convenções das Nações Unidas em vigor acerca da matéria e abrange tópicos que vão desde o seqüestro de reféns até os atentados com explosivos, passando pelo financiamento do terrorismo. $\mathrm{O}$ grande obstáculo às negociações reside justamente na dificuldade em se delimitar o conceito de terrorismo, o que não é, contudo, o único impasse. Outras questões também têm criado embaraços neste processo, tais como:

Rio de Janeiro. 2007. Dissertação (Mestrado em Relações Internacionais) - Departamento de Relações Internacionais, PUC-RIO. p. 18.

${ }^{40}$ Foi sétimo secretário-geral da ONU no período entre $1^{\circ}$ de janeiro de 1997 e $1^{\circ}$ de janeiro de 2007. Foi laureado com o Prêmio Nobel da Paz em 2001.

${ }^{41}$ DEEN, Thalif. Nações Unidas: Em busca de uma definição para terrorismo. IPS-Inter Press Service, 27 mai. 2005 Disponível em <http://www. mwglobal.org/ipsbrasil.net/nota.php?idnews=831>. Acesso em 20 mai. 2009. 
"o que distingue uma 'organização terrorista' de um 'movimento de libertação'? Podem ser excluídas as atividades de forças armadas regulares, mesmo quando cometam atos considerados terroristas? Pode-se falar de 'terrorismo de Estado'? Diplomatas árabes argumentam que qualquer definição exaustiva de terrorismo deve incluir o conceito de 'terrorismo de Estado' e distinguir o conceito do direito à autodeterminação dos povos. ${ }^{, 42}$

Segundo a Comissão Interamericana de Direitos Humanos, a linguagem do terrorismo é empregada em uma ampla variedade de contextos e com graus distintos de formalidade para caracterizar:

- “Acciones, que incluyem formas de violencia como los secuestros.

- Actores, incluidas personas u organizaciones.

- Causas o luchas, en que la causa o lucha puede estar tan marcada por la violencia terrorista que la hacen indistinguible de ésta, o en que un movimiento puede cometer actos aislados de terrorismo o empreender estrategias terroristas. Es particularmente em este sentido que se há planteado la falta de acuerdo em torno a uma definición integral del terrorismo debido a que ciertos Estados han considerado que lo que com frecuencia se denominam 'movimientos de liberación nacional' y sus metodologias deben ser excluidos de toda definición de terrorismo en razón de su asociación con el principio del libre determinación de los pueblos.

- Situaciones em que la violencia terrorista es um problema particularmente grave o difundido en una región, Estado u otra zona.

- Conflictos armados en el sentido, por ejemplo, de la denominada 'guerra contra el terrorismo' posterior al 11 de septiembre de 2001."43

Embora haja extrema discordância conceitual na comunidade internacional, poder-se-ia afirmar, como se observa no artigo 2 da Convenção Interamericana Contra o Terrorismo, que se tem identificado alguns atos entendidos como formas de terrorismo, como, por exemplo, o seqüestro e a destruição de aeronaves civis, a tomada de reféns, os atentados à vida de pessoas internacionalmente protegidas, como os agentes

\footnotetext{
${ }^{42}$ DEEN, Thalif. Nações Unidas: Em busca de uma definição para terrorismo. IPS-Inter Press Service, 27 mai. 2005. Disponível em <http://www.
} mwglobal.org/ipsbrasil.net/nota.php?idnews=831>. Acesso em 20 mai. 2009.

${ }^{43}$ COMISIÓN INTERAMERICANA DE DERECHOS HUMANOS. Op. cit. p. 20. 
diplomáticos, e as ameaças de violência que visem primeiramente aterrorizar a população civil. $^{44}$

Thomas Butko, ao fazer menção a David Whittaker, admite a possibilidade de haver mais de cem definições distintas ${ }^{45}$ e reproduz algumas destas acepções. Para Martha Crenshaw, "terrorism means socially and politically unacceptable violence aimed at an innocent target." 46 Brian Jenkins defende que "[...] the word terrorism has commonly come to mean violent acts carried out randomly against nonmilitary, civilian targets, with the aim of inspiring fear in the wider population." 47 Já a definição de Gregory Raymond é a seguinte: "Political terrorism entails the deliberate use of threat of violence against noncombatants, calculated to instill fear, alarm, and ultimately a feeling of helplessness in an audience beyond the immediate victims." 48 Por fim, Butko faz referência, mais uma vez, a David Whitaker, que entende que "it ought to be possible to secure some fundamental definition that regards the work of terrorists as intentional use of violence against non-combatant civilians aimed at reaching political ends. "49

Sem embargo, apesar da existência de uma vasta gama de conceitos, Butko nota que é possível identificar três elementos presentes na maioria

\footnotetext{
${ }^{44}$ Ibid. p. 22-23.

${ }^{45}$ BUTKO, Thomas. Terrorism redefined: terrorism as "counter-hegemonic political violence". In: 2005 CPSA Annual Conference. Ottawa: Canadian Political Science Association, 2005. Disponível em <http://www.cpsa-acsp.ca/template_e.cfm?folder =conference\&page_name=agmpapers-2005.htm>. Acesso em 19 mai. 2009. p.2

${ }^{46}$ Ibid. p. 4.

${ }^{47}$ Ibid. p. 4.

${ }^{48}$ Ibid. p. 2

${ }^{49}$ Ibid. p. 2
} 
deles: a) o uso ou a ameaça de violência; b) a finalidade política; e c) os efeitos psicológicos em vítimas inocentes. ${ }^{50}$

Esta tríade pode ser verificada também na visão americana de terrorismo, segundo “Os Padrões de Terrorismo Global - 2000”, divulgados

no ano de 2001, pelo então Coordenador Interino de Contra-terrorismo, Edmund J. Hull:

"Nenhuma definição de terrorismo obteve aprovação universal. Para os propósitos deste relatório, no entanto, nós escolhemos a definição de terrorismo contida no Título 22 do Código dos Estados Unidos, artigo 2656f(d). Essa lei contém as seguintes definições:

-O termo "terrorismo" significa violência premeditada, com motivação política, cometida contra alvos não-combatentes por grupos sub-nacionais ou agentes clandestinos, geralmente com o objetivo de influenciar um público.

-O termo "terrorismo internacional" significa terrorismo envolvendo cidadãos ou o território de mais de um país.

-O termo "grupo terrorista" significa qualquer grupo que pratique terrorismo internacional, ou tenha subgrupos significativos que pratiquem terrorismo internacional. O governo americano emprega essa definição de terrorismo para fins estatísticos e analíticos desde 1983.

Terrorismo doméstico é provavelmente um fenômeno mais difundido do que terrorismo internacional. Tendo-se em vista que o terrorismo internacional tem um impacto direto nos interesses dos Estados Unidos, é o foco principal deste relatório." 51

O mesmo documento explicita o que se entende por "não combatente", em outras palavras, alvos civis:

"Para fins dessa definição, interpreta-se o termo 'não-combatente' de modo a incluir, além de civis, o pessoal militar que à época do incidente não estava armado ou não estava em serviço. Por exemplo, em relatórios anteriores nós incluímos na lista de incidentes terroristas o assassinato do seguinte pessoal militar dos Estados Unidos: coronel James Rowe, morto em Manila em abril de 1989; capitão William Nordeen, adido militar americano morto em Atenas em junho de 1988; os dois soldados mortos no bombardeamento da discoteca Labelle em Berlim Ocidental em abril de 1986 e os quatro fuzileiros navais do navio US

\footnotetext{
${ }^{50}$ Ibid. p. 1 e 3.

${ }^{51}$ DEPARTAMENTO de Estado dos Estados Unidos. Padrões de Terrorismo Global - 2000. Embaixada Americana no Brasil. 2001. Disponível em <http://terrorismo.embaixadaamericana.org.br/ 2000 intro.htm>. Acesso em 25 abr. 2009.
} 
Embassy, que não estavam em serviço, mortos em um café em El Salvador em junho de 1985. Nós também consideramos como atos de terrorismo os ataques a instalações militares ou a pessoal militar armado quando um estado de hostilidade militar não existe no lugar, como bombardeamento às bases americanas na Europa, nas Filipinas, ou em outros lugares." 52

Butko assinala que, em uma geração do medo como a nossa e dado que a prática de terrorismo não requer a efetiva prática da violência (bastando a ameaça), talvez o componente que melhor defina o terrorismo seja a ameaça ou o dano que direciona a civis inocentes. E acrescenta que, independentemente das ações terroristas serem diretas ou indiretas, matarem, causarem dano físico ou psicológico ou meramente provocarem intimidação, é o impacto que elas têm nas pessoas concebidas como inocentes que constituem o seu principal atributo. ${ }^{53}$

Porém, pode ser complicado e ambíguo se distinguir claramente combatentes de não combatentes, alvos legítimos de ilegítimos e inocentes de não inocentes. Isto se levando em conta que, às vezes, determinadas pessoas podem contribuir com políticas vistas como opressivas e injustas por outras. Além do mais, o fato de que civis "inocentes" são mortos não condena, necessariamente, uma ação como "terrorista" ou "imoral". ${ }^{54}$

Outro ponto pertinente é que, em todas as definições e características vistas, pouco importa se é o agente é estatal ou não-estatal, ou seja, as duas hipóteses seriam cabíveis. Exceto, naturalmente, na definição adotada pelo governo americano, na qual atos de terrorismo são praticados tão-somente por "grupos subnacionais ou agentes clandestinos", entendimento este que é partilhado por alguns estudiosos. ${ }^{55}$

\footnotetext{
${ }^{52}$ Ibid.

${ }^{53}$ BUTKO, Thomas. Op. Cit. p. 3 e 4.

${ }^{54}$ Ibid. p. 5.

${ }^{55}$ Ibid. p. 5-6.
} 
Ao ver de Butko, tal definição é problemática porque contraria a natureza da atividade terrorista ao longo da história. Até mesmo no Ocidente, onde a visão de terrorismo geralmente é personificada por grupos como a Al-Qaeda, pois mesmo estes recebem subsídios de países como a Síria ou o Irã, que também têm apoiado organizações consideradas como "terroristas" pelo Ocidente, como o Hezbollah, no sul do Líbano, e o Hamas, nos territórios ocupados. ${ }^{56}$

Assim, constata o autor que não há dúvida de que os Estados podem, não só financiar grupos vistos como "terroristas", como podem também ser os próprios agentes a lançarem mão da violência e da força.

\section{2 "Terrorismo de Estado"?}

Butko afirma que não deveria causar espanto o uso da expressão "terror de Estado", vez que a concepção de "terrorismo" originalmente se aplicava ao Estado jacobino na França, o qual consistia em terrorismo “aplicado pelo Estado". ${ }^{57}$ Richard Falk, mencionado por Butko, destaca que há confusão porque a essência do terrorismo, remontando às suas origens na Revolução Francesa, diz respeito ao uso calculado da violência com finalidades políticas contra a população civil para espalhar o medo, e os governos são tão inclinados a recorrer a este método, quanto seus oponentes. $^{58}$

Ao se considerar os três aspectos essenciais do "terrorismo" vistos anteriormente, pode-se perceber que há muitos outros perpetradores de tal prática do que são geralmente reconhecidos. Butko alerta que, em um

\footnotetext{
${ }^{56} \mathrm{Ibid}$. p. 6.

${ }^{57}$ Ibid. p. 6.

${ }^{58}$ Ibid. p. 6-7.
} 
sistema que concebe o mundo como hobbesiano (guerra de todos contra todos) e em que a teoria "realista" é a que predomina na abordagem das relações internacionais, não se pode negar que todos os Estados se utilizam de violência para provocar medo com algum fim político, sobretudo os países dominantes. Segundo Michael Stohl, através da história "terrorism is most frequently used by governments to mantain Power". ${ }^{59}$ Os maiores exemplos disso foram os Estados totalitários, como a União Soviética de Joseph Stalin e a Alemanha nazista de Adolph Hitler. ${ }^{60}$

Falk aponta que a definição limitada de terrorismo, que não vislumbra o Estado como possível agente, seria politicamente incoerente, pois ignora evidências históricas como, por exemplo, o fato de que os Estados Unidos apoiaram a violência política "anti-estatal" na Nicarágua nos anos $80 . .^{61}$

Numa análise mais atual, levando-se em conta três acontecimentos recentes de grande repercussão, conclui-se que todos vitimaram pessoas inocentes. São eles: a atuação americana no Afeganistão e no Iraque; as ações israelitas nos territórios ocupados, particularmente ataques de mísseis a campos de refugiados na Faixa de Gaza; e, sobretudo, a ofensiva da Rússia (que, a propósito, é aliada dos EUA na "guerra ao terror") na Chechênia, que devastou a capital do país, Grózni, e deixou milhares de mortos. $^{62} 63$

\footnotetext{
${ }^{59}$ Citado por Butko. Ibid. p. 6.

${ }^{60}$ Ibid. p. 6.

${ }^{61}$ Ibid. p. 7.

${ }^{62}$ Ibid. p. 7-8.

${ }^{63}$ Segundo o Aslambek Kadiev*, representante da Chechênia na União Européia, as principais razões russas para as duas guerras com aquele país estão ligadas, primeiro, à questão econômica e ao controle e distribuição do petróleo do Cáucaso e, segundo, a questões da política interna russa, como a reeleição de Boris Yeltsin em 1996 e a sucessão de Wladimir Putin em 1999. Na primeira Guerra da Chechênia, ocorrida de 1994 a 1996, o então presidente russo Boris Yeltsin suprime a autonomia da Chechênia. Milhares de pessoas morreram ou ficaram refugiadas. Vários atentados terroristas sacodiram a Rússia. Com efeito, a guerra foi encerrada pelo Acordo de Khasavyurt e
} 
Se seguirmos a noção e os elementos do "terrorismo" já expostos, os três eventos acima, assim como tantos outros do gênero, enquadram-se perfeitamente no conceito de "terrorismo". Por esta razão é que Chomsky afirma que a definição de terrorismo formulada no governo de Ronald Reagan, contida no Código dos Estados Unidos (U.S. Code) ${ }^{64}$, não é mais utilizada, pois é praticamente a mesma que definiria "contraterrorismo" (também chamado de "conflito de baixa intensidade" ou "contrainsurgência") e, portanto, sugeriria que os EUA são terroristas. ${ }^{65}$

Como não se admite que este tipo de conduta seja enquadrado como ato "terrorista", deve haver elementos importantes que são omitidos das definições contemporâneas de "terrorismo", o que as torna imprecisas, se não equivocadas. ${ }^{66}$

Nesta esteira, para João Ricardo Dornelles,

com a vitória dos independentistas, em fevereiro de 1996. Na segunda Guerra da Chechênia, no periodo de 1999 a 2004, em resposta aos violentos atentados terroristas em Moscou, o presidente Putin ordena o bombardeamento e a destruição de Grózni, a capital chechena. Nas batalhas, Grózni, foi reduzida a escombros. Mais de um terço da população abandonou a cidade. Em 2002, a ONU declarou-a como a cidade mais destruída do planeta. Nos últimos oito anos, milhares de jovens chechenos, homens e mulheres desapareceram. Os Kadyrovtsy, grupo guerilheiro comandado pelo atual presidente checheno Ramzan Kadyrov é acusado por grupos de defesa dos direitos humanos de abusos sistemáticos, seqüestros, tortura e assassinatos. No total das duas guerras, estima-se que tenham morrido cerca de cem mil chechenos, ou seja, dez por cento da população.** *KADIEV, Aslambeck. A guerra da Rússia, na ótica da Chechênia. BBC Brasil, Grózni, 28 dez. $1999 . \quad$ Disponível <http://www.bbc.co.uk/portuguese/omundohoje/omh99122805.htm>. Acesso em 19 mai. 2009. **WINGFIELD-HAYES, Rupert. Análise: Questão da Chechênia está longe da resolução. $B B C$ Brasil, $\quad$ Moscou, $16 \quad$ abr. $2009 . \quad$ Disponível <http://www.bbc.co.uk/portuguese/noticias/2009/04/090416_analisechecheniamv.shtml>. Acesso em 19 mai. 2009.

64 "' Um ato de terrorismo que dizer qualquer atividade que a) envolva um ato violento ou uma séria ameaça à vida humana que seja considerado delito pelos Estados Unidos ou qualquer outro Estado, ou que seja delito assim reconhecido, se praticado dentro do território jurisdicional americano ou de qualquer outro Estado; e b) aparente (i) ser uma intimidação ou coerção à população civil; (ii) influencie a política governamental por meio de intimidação ou coerção; ou (iii) ameace a conduta de um governo por um assassinato ou seqüestro. (United States Code Congressional and Administrative News. 98 Congresso, Segunda Sessão, 19 de outubro de 1984, vol. 2, par. 3077, 98 STAT. 2707).” CHOMSKY, Noam. Op. cit. p. 17.

${ }^{65}$ CHOMSKY, Noam. Império americano: hegemonia ou sobrevivência. Rio de Janeiro: Elsevier, 2004. p. 190 e 191.

${ }^{66}$ BUTKO, Thomas. Op. cit. p. 7-8. 
"a discussão sobre o que é terrorismo deve considerar o poder de definição por parte de quem tem poder. Trata-se, portanto, da expressão de uma relação de poder. [...] A questão do terrorismo não se restringe aos seus aspectos técnicojurídicos, ou mesmo às ações violentas na prática política. Na realidade, trata-se de um tema político por excelência." ${ }^{, 67}$

Butko, a seu turno, recorre à conceituação de "hegemonia" dada por Antonio Gramsci para elucidar a questão. A intenção primeira do italiano ao definir o termo era demonstrar que a força e a coerção não eram as únicas táticas usadas pelo Estado para manter o controle sobre as massas. $\mathrm{O}$ uso da força, especialmente através dos sistemas militar, judicial e policial, e a estrutura econômica, desempenhariam papel fundamental, mas seriam os "elementos consensuais" os mais importantes neste processo. ${ }^{68}$

Para Gramsci, o poder estatal seria mantido através da coerção e do consentimento. Este último se daria pelo poder intelectual, cultural e moral do Estado, representado pela sua capacidade de promover conjuntos de valores, crenças e idéias que contribuem para manter a posição das classes dominantes. Nas palavras de Gramsci, "the supremacy of a social group manifests iteself in two ways, as 'domination' and as 'intellectual and moral leadership’." 69 É o que ele chama de "hegemonia ideológica”, que dotaria o Estado de uma função moral ou ética, de educador em termos de valores e crenças, para além de mero detentor do monopólio da força.

Diversos autores, como Stephen Gill e Mark Rupert, têm transferido a idéia de Gramsci de "hegemonia", que se referiu estritamente ao plano doméstico, para o plano externo ${ }^{70}$, afirmando ser plenamente aplicável no âmbito internacional, em que se poderia identificar uma crescente "classe

\footnotetext{
${ }^{67}$ DORNELLES, João Ricardo W. Op. cit. p. 14.

${ }^{68}$ BUTKO, Thomas. Op. cit. p. 8-9.

${ }^{69}$ Ibid. p. 9.

${ }^{70} \mathrm{O}$ que foi feito pela primeira vez por Robert Cox, em 1983, estendendo noções gramscianas para o contexto internacional. Ibid. p. 10.
} 
capitalista transnacional". ${ }^{71}$ Tal classe se valeria de instrumentos militares e coercitivos das potências ocidentais para manter seu status quo, mas seria a disseminação dos valores ocidentais do liberalismo, livre mercado, consumismo e democracia que garantiriam o seu controle hegemônico. Isto estaria ligado à sua habilidade de manipular o pensamento e os desejos dos grupos dominados e de passar a impressão de que o sistema é bom e beneficia a todos, quando, na realidade, é conduzido em função exclusivamente dos interesses de quem está no poder - contando para isso, com a exímia colaboração da mídia e de outros formadores de opinião ${ }^{72}$. A esse respeito, Dornelles assinala que

"[u]ma mágica que faz com que ninguém perceba as suas próprias práticas de terror. Ou que transforme as suas próprias práticas terroristas em ações positivas, apresentadas como benéficas para a humanidade. [...] Um processo de alienação coletiva que inverte a avaliação sobre os acontecimentos." ${ }^{, 73}$

Além disso, as potências ocidentais mantêm sua hegemonia não só difundindo seus valores e idéias, mas também igualando a moral e a cultura ocidentais ao próprio conceito de "civilização", criando a dicotomia “civilização" versus "barbárie". Dornelles ressalta que isto ficou ainda mais claro após os ataques ao World Trade Center e ao Pentágono:

"A partir de 11 de setembro de 2001, e da ofensiva militarista, a Doutrina Bush determinou uma nova fronteira, uma nova polarização, um novo limite onde de um lado está a civilização (representada pela cultura ocidental e pela ordem neoliberal) e do outro lado, a barbárie."74

Com efeito, os "terroristas" passam a ser encarados como ameaças à própria civilização como um todo e são transformados em uma verdadeira personificação do "mal", forjando uma falsa luta entre "bem" e "mal". Tal

\footnotetext{
${ }^{71}$ Ibid. p. 11.

${ }^{72}$ DORNELLES, João Ricardo W. Op. cit. p. 8.

${ }^{73}$ Ibid. p. 15.

${ }^{74}$ Ibid. p. 16.
} 
visão é ainda sustentada por governos e políticos, a exemplo da administração de George W. Bush, o que ficou explícito quando o expresidente dos EUA, referindo-se ao Iraque, Irã e Coréia do Norte, passou a empregar o termo "eixo do mal". 75

Dornelles aponta que a propaganda dos meios de comunicação constrói

"a imagem positiva ou negativa de governantes, indivíduos, povos, países, religiões, etnias e raças. O estereótipo do mal já apresentou diferentes feições: indígena, africana, japonesa, chinesa, russa, latino-americana, árabe, indiana. Em geral, o bem é apresentado com um rosto ocidental, europeu. É a construção de figuras do mal no imaginário social, encarnados nas imagens de Osama Bin Laden, Saddam Hussein, Fidel Castro, Hugo Chávez, Yasser Arafat, ou algum outro político ou personalidade que não tenha um comportamento submisso em relação aos 'donos do poder mundial' ou se coloque com uma postura hostil aos interesses do poder dominante. Vale à pena lembrar que muitos destes 'representantes do mal' foram criados, formados e financiados pelo governo norte-americano." 76

Acrescenta o autor que foi a própria CIA $^{77}$ que formou os primeiros "terroristas" 78 , tendo financiado e armado

“os chamados 'guerreiros de deus', 'mujahedins' e talibãs anticomunistas para lutarem no Afeganistão uma 'guerra justa e santa' contra as 'forças do mal' soviéticas. Naquele momento, começava a carreira de Osama Bin Laden." 79

Ao longo da história, desde que a palavra "terrorismo" teve seu primeiro uso contemporâneo, na Revolução Francesa, ela vem sido empregada unicamente para designar grupos e indivíduos que se recusam a

\footnotetext{
${ }^{75}$ Bush utilizou o termo "eixo do mal" pela primeira vez em seu discurso anual sobre o estado da União, proferido diante do Congresso norte-americano em 29 de janeiro de 2002. MARTIN, David. Bush Takes On 'Axis Of Evil': U.S. Restores Funding To Iraqi Opposition Group. $C B S$ News, $\quad 30 \quad$ jan. $2002 . \quad$ Disponível em <http://www.cbsnews.com/stories/2002/01/30/terror/main326225.shtml. Acesso em 10 abr.2009>. Acesso em 30 abr. 2009.

${ }^{76}$ DORNELLES, João Ricardo W. Op. cit. p. 14-15.

${ }^{77}$ Agência Central de Inteligência dos Estados Unidos (Central Intelligence Agency).

${ }^{78}$ CHOMSKY, Noam. Império americano: hegemonia ou sobrevivência. p. 210.

${ }^{79}$ DORNELLES, João Ricardo W. Op. cit. p. 14.
} 
consentir com a hegemonia dos poderes dominantes no sistema internacional. Butko sintetiza bem a questão ao citar Beril Dedeoglu: "In other words, actors capable of defining the international system rules can define certain facts that seem in opposition to their way of existence as manifestations of 'terror' and thus identify them as 'other'., 80

Tais grupos ou indivíduos classificados como "terroristas" já foram rotulados como anti-democráticos, anti-cristãos (e até mesmo "anti-Deus"), anti-capitalistas, anti-ocidentais e anti-americanos, e, em todos os casos, desde dos radicais da Revolução Francesa, passando pelos comunistas e pelos nacionalistas do terceiro mundo, até os fundamentalistas islâmicos de hoje, sempre foram vistos como uma ameaça aos poderes hegemônicos de seu tempo ${ }^{81}$.

Assim sendo, Butko indica que é possível identificar um padrão para o tipo de ameaça oferecida aos poderes dominantes pelas diversas modalidades de "terrorista" que fizeram parte da história contemporânea. Desde a Revolução Francesa até a primeira parte do século XX, o principal desafio aos poderes hegemônicos vinha de dentro dos países ocidentais. Tal revolução significou um brusco afastamento da monarquia e da estrutura política dos séculos anteriores, tendo representado um momento decisivo no terrorismo moderno, não por sua dimensão, pois já tinham acontecido massacres muito maiores na história, mas por ter desafiado os interesses das elites hegemônicas da época.

Até meados do século XIX, quem assumiu o "papel" de "terroristas" foram os democratas radicais e outros membros da classe média liberal que se opuseram ao domínio da classe conservadora deste período. A terceira categoria de ameaças internas, que durou quase um século, foi formada pelos anarquistas na Rússia e pelas organizações socialistas na Europa, que

\footnotetext{
${ }^{80}$ BUTKO, Thomas. Op. cit. p. 13.

${ }^{81}$ Ibid. p. 12.
} 
demandavam mais participação política e poder econômico. Estes grupos nasceram da classe trabalhadora e dos sindicatos burgueses e, mais tarde, culminaram no movimento comunista mundial. No plano doméstico, o ponto alto do movimento anarquista era a sua contraposição ao regime czarista. Todavia, com o assassinato do czar Alexandre II, em 1881, e do presidente norte-americano William McKinley, em 1901, o movimento tomou outras proporções e passou a ser encarado como uma ameaça a toda a ordem mundial. Logo após o assassinato McKinley, o seu sucessor, Franklin Roosevelt declarou em conferência que estes grupos e indivíduos ameaçavam "todos os poderes civilizados". Tal movimento foi percebido como sendo ainda mais grave do que as versões anteriores de "terroristas", tendo em vista que, além de contestar o status quo dos detentores do poder, era nitidamente anti-cristão, anti-democrático e, acima de tudo, anticapitalista. ${ }^{82}$

Destarte, o terrorismo passou a ser visto, não mais como uma contestação interna aos poderes dominantes, mas como uma ameaça externa e global a todo o controle hegemônico do sistema internacional. O que ficou claro com a Revolução Russa de 1917. A ameaça da "esquerda radical" não desapareceu após o declínio do movimento anarquista, mas foi substituída pelo comunismo, que permaneceu como a ameaça número à hegemonia ocidental até o final dos anos 80. Anti-capitalista, anti-democrático e anticristão, quer fosse orientado pela União Soviética, China ou Cuba, passou a ser visto como o responsável por todo o "terrorismo" no mundo. Esta realidade se tornou mais evidente no final da década de 1970 e início da década de 1980, na medida em que a atividade "terrorista" parecia estar aumentando. Isto foi agravado pelas declarações do presidente dos Estados

${ }^{82}$ Ibid. p. 15-19. 
Unidos, Ronald Reagan, em 1983, acerca da existência de um "Império do Mal". 83

Os movimentos nacionalistas e de libertação que surgiram nos países de terceiro mundo após a Segunda Guerra Mundial constituíram outra figura do "terrorismo", que, apesar de ser motivados pela luta pelo direito de autodeterminação e pela independência de seus países - o que, segundo eles, os diferenciava da atividade "terrorista" na Europa -, foram confundidos, por vezes, com o movimento comunista. Muitos defendiam tratar-se de terrorismo independentemente de suas motivações, o que contribuiu para a projeção do movimento do plano estatal para o internacional, transformando os esforços de emancipação do terceiro mundo em ameaça ao poderio ocidental.

$\mathrm{Na}$ atualidade, ainda restam porções do "terrorismo" comunista ${ }^{84} \mathrm{e}$ nacionalista $^{85}$ no mundo. Entretanto, o que se constata é que a dita ameaça do comunismo mundial foi substituída pelo fundamentalismo islâmico, que passou a ser encarado como a principal ameaça à hegemonia do Ocidente (leia-se dos Estados Unidos) e o novo inimigo da civilização ocidental. ${ }^{86}$ Isto também fica evidenciado pelo fato de que três dos quatro Estados

\footnotetext{
${ }^{83}$ Ibid. p. 19.

${ }^{84}$ Cuba ainda permanece na lista do governo norte-americano de Estados que patrocinam o terrorismo. UNITED STATES DEPARTMENT OF THE TREASURY. Office of Foreign Assets Control. Terrorist Assets Report. Calendar Year 2007 Sixteenth Annual Report to Congress on Assets in the United States of Terrorist Countries and International Terrorism Program Designees Office. Disponível em <http://www.ustreas.gov/offices/enforcement/ofac/reports/tar2007.pdf>. Acesso em 31 mai. 2009. p. 9.

${ }^{85}$ Como grupos "internos" (dentro da Europa), podem-se citar o IRA (Exército Republicano Irlandês) e o ETA (Pátria Basca e Liberdade), e como organizações "externas" (fora da Europa), o PLO (Grupo para Libertação da Palestina) e o Tigres Tamil do Sri Lanka. BUTKO, Thomas. Op. cit. p. 21.

${ }^{86}$ DORNELLES, João Ricardo W. Op. cit. p. 13.
} 
atualmente na lista do governo norte-americano dos países patrocinadores do terrorismo são islâmicos: Irã, Sudão e Síria. ${ }^{87} 88$

O novo inimigo possui todos os aspectos "anti-isso" e "anti-aquilo" dos seus antecessores. Com efeito, não surpreende que a idéia de Samuel Huntington do "choque de civilizações" tenha sido aceita e promovida por aqueles que vêem o mundo islâmico como séria ameaça. Segundo Dornelles, Huntington dividiu o mundo em "o Ocidente e os outros" e defende que os valores da liberdade, igualdade, democracia, constitucionalismo, liberdade de mercado, individualismo e direitos humanos são próprios do ocidente; portanto, frente às ameaças trazidas pelos "outros" e aos ataques "injustos" ao "estilo de vida da América", caberia aos Estados Unidos liderar a luta pela defesa dos valores ocidentais. Tal conjectura dotou os executores da política externa americana de uma base teórica conveniente e legitimadora. ${ }^{89}$

O enorme poder político e moral que os Estados Unidos já possuíam de classificar seus inimigos como "terroristas" aumentou ainda mais com os atentados de 11 de setembro. ${ }^{90}$ Dornelles afirma que tal episódio "serviu ‘como uma luva' aos interesses da aliança de poder que governa os Estados

${ }^{87}$ UNITED STATES DEPARTMENT OF THE TREASURY. Office of Foreign Assets Control. Terrorist Assets Report. Calendar Year 2007 Sixteenth Annual Report to Congress on Assets in the United States of Terrorist Countries and International Terrorism Program Designees Office. Disponível em <http://www.ustreas.gov/offices/enforcement/ofac/reports/tar2007.pdf>. Acesso em 31 mai. 2009. p. 9.

${ }^{88}$ Anteriormente, cinco dos sete países da lista eram islâmicos. O Iraque e a Líbia (e a Coréia do Norte) foram removidos recentemente (a emenda de alteração da lista oficial entrou em vigência em 18.5.2009). O Afeganistão já tinha sido retirado da lista após a ocupação americana de 2001 e o início do governo pró-americano de Hamid Karzai. UNITED STATES DEPARTMENT OF THE TREASURY. Office of Foreign Assets Control. Terrorism List Governments Sanctions Regulations. $\quad 182009.2$ mai. 200 Disponível <http://www.treas.gov/offices/enforcement/ofac/legal/regs/fr74_23111.pdf>. Acesso em 31 mai. 2009.

${ }^{89}$ DORNELLES, João Ricardo W. Op. cit. p. 4-5.

${ }^{90}$ BUTKO, Thomas. Op. cit. p. 23. 
Unidos e aos planos de ocupação militar da Ásia Central e do Golfo Pérsico". 91

Neste sentido, tudo leva a crer que a escolha dos muçulmanos como os terroristas da vez não se deu por mera coincidência, mas estaria intimamente ligada ao fato de a Arábia Saudita, o Iraque e o Irã estarem entre os maiores produtores de petróleo do mundo, de modo que "os interesses econômicos da ordem global neoliberal servem de fundamento para conflitos no cenário internacional.",92

Diante disso, é possível se identificar historicamente quem foram os indivíduos ou grupos designados como "terroristas" e perceber quais características lhes são comuns. Por outro lado, levando-se em consideração os elementos mencionados previamente, não se pode definir objetivamente o que é terrorismo e quem são os terroristas, já que muitos não-terroristas se utilizam de violência para atingir objetivos políticos, acarretando a morte de civis inocentes.

Por conseguinte, apenas as forças dominantes detêm o poder coercitivo e a habilidade moral e intelectual para classificar e rotular os seus opositores como "terroristas". Este propósito é alcançado mediante políticas dos Estados dominantes ou com o auxílio de instituições internacionais, como a própria ONU.

Embora não haja definição oficial da ONU, como já afirmado, Malvina Halberstam expõe que

"The United Nations position on terrorism has changed over the last three decades from one that, at least arguably, permitted terrorism in support of the struggle for self-determination, to one that unequivocally condemns terrorism as criminal and unjustifiable wherever and by whomever committed." 93

\footnotetext{
${ }^{91}$ DORNELLES, João Ricardo W. Op. cit. p. 10.

${ }^{9}$ Ibid. p. 4.

${ }^{93}$ Apud BUTKO, Thomas. Op. cit. p. 24.
} 
Butko adota uma posição construtivista a respeito de terrorismo, segundo a qual as definições e classificações do fenômeno seriam socialmente construídas. E acrescenta que:

"Since terrorism is socially and politically constructed, it is a process of communication rooted in language itself and, thus, involves creating or imposing a bridge of shared meanings. In this sense, the actual act of defining 'terrorism' has as its ultimate function a general and overall process of delegitimization."’4

Assim, o termo tem sido aplicado, basicamente, como rótulo para deslegitimar os que contestam os detentores do poder. A única diferença entre atos terroristas e não terroristas seria dada pelo fato de ser o agente hegemônico ou não. Por esta razão, Butko defende que terrorismo pode ser melhor explicado como "violência política contra-hegemônica". 95

Noam Chomsky argumenta que os Estados se utilizam freqüentemente de violência contra inocentes para atingir seus objetivos e que a isso se poderia sim dar o nome de terrorismo ${ }^{96}$. Afirma que não haveria outro nome adequado para tal prática. Nas palavras do autor:

"Não sei que nome se dá ao tipo de política que se constitui na principal causa da morte de, quem sabe?, milhões de civis no Iraque, entre eles talvez meio milhão de crianças, que é o preço que o secretário de Estado diz que nós estamos dispostos a pagar. Há algum nome para isso?"97

Vale lembrar que os Estados Unidos foram o único Estado no mundo a ser condenado por terrorismo internacional pela Corte Internacional de Justiça, cujos julgamentos de mérito foram concluídos em $1986 .{ }^{98}$

\footnotetext{
${ }^{94}$ Ibid. p. 30.

${ }^{95}$ Ibid. p. 1.

${ }^{96}$ CHOMSKY, Noam. 11 de setembro. p. $48-49$.

${ }^{97}$ Ibid. p. 49.
}

${ }^{98}$ INTERNATIONAL COURT OF JUSTICE. Military and Paramilitary Activities in and against Nicaragua (Nicaragua v. United States of America). Disponível em <http://www.icj- 
Chomsky afirma que os EUA são um "Estado líder do terrorismo". Segundo ele, várias são as evidências disso, sendo a invasão da Nicarágua a mais extrema. Na década de 1980, a Nicarágua foi invadida pelos EUA e milhares de pessoas morreram, ao mesmo tempo em que ocorreu uma guerra econômica. Como resultado, o país foi devastado e nunca mais conseguiu se refazer. Chomsky avalia que os efeitos deste ataque foram de longe mais severos que os dos atentados de 11 de setembro. Ele observa que a resposta da Nicarágua não foi tentar bombardear Washington, mas recorrer à Corte Internacional de Justiça que ordenou que os EUA pagassem uma indenização ao país. Os EUA, por sua vez, desconsideraram e não cumpriram a sentença, procedendo a novos ataques à Nicarágua. Esta, então, levou a questão ao Conselho de Segurança da ONU, que elaborou uma resolução determinando que todos os países deveriam respeitar as leis de Direito internacional. Os Estados Unidos foram os únicos a vetarem a resolução. Como último recurso, a Nicarágua recorreu à Assembléia Geral da ONU, a qual discutiu resolução semelhante, que sofreu oposição dos EUA e de Israel por dois anos seguidos (contando temporariamente com o apoio de El Salvador). Sem perspectiva de sucesso, a Nicarágua desistiu. Se tivesse mais influência, poderia ter convocado outro julgamento internacional. Em vez de partir para a retaliação, após 11 de setembro, os EUA deveriam ter utilizado os recursos do Direito internacional e, nesse caso, ninguém teria como vetá-los. ${ }^{99}$

É por situações como esta, que Chomsky defende que o terrorismo não é "a arma dos fracos", como se costuma dizer, mas, a exemplo da maioria das armas mortíferas, é "a arma dos poderosos". Quando se diz o contrário, é apenas porque os detentores do poder controlam os aparelhos

cij.org/docket/index.php?p1=3\&p2=3\&k=66\&case=70\&code=nus \&p3=4>. Acesso em 29 mai. 2009.

55 CHOMSKY, Noam. 11 de setembro. p. 48.

${ }^{99}$ Ibid. p. 27-28. 
ideológicos e culturais, o que faz com que o terror deles não seja visto como tal. ${ }^{100}$

Assim sendo, é possível perceber que há uma profunda incoerência nesse sistema de dois pesos e duas medidas. Quando a violência é cometida pelos dominados, como forma de oposição, é "terrorismo". Quando cometida pelos detentores do poder, é "legítima defesa" ou "intervenção humanitária", ainda que tais ações sejam mais violentas e causem mais mortes do que as ações taxadas de "terroristas". Dornelles expõe que

"[d]urante décadas, em nome da democracia e dos direitos humanos, os Estados Unidos realizaram intervenções em todo o mundo, resultando em milhões de mortes. Estas intervenções poderiam ser consideradas atos de terror? O discurso do poder informa que muitas delas são 'humanitárias'." 101

A guerra do Iraque é um exemplo gritante disto, que, com mais de 110 mil civis mortos ${ }^{102}$, superou, em muito, as cerca de 3 mil vítimas dos ataques às Torres Gêmeas em 2001. Diante desta realidade, a afirmação de Chomsky não poderia ter sido mais perspicaz: "É difícil escapar da conclusão de que, em um nível mais profundo, muito embora possam negálo para si mesmos, eles encaram seus crimes contra os mais fracos como tão normais quanto o ar que respiram." 103

\footnotetext{
${ }^{100}$ CHOMSKY, Noam. Império americano: hegemonia ou sobrevivência. p. 191.

${ }^{101}$ DORNELLES, João Ricardo W. Op. cit. p. 14.

10287.215 pessoas morreram no país desde 2005 em decorrência da guerra. No total, desde a invasão dos Estados Unidos, em 2003, a estimativa é de que 110.600 iraquianos tenham morrido. Tal número diz respeito a mortes violentas e a expectativa é de que o total de vítimas seja de 10 a $20 \%$ maior, contabilizando desaparecidos e mortos não registrados. ASSOCIATED PRESS. Quase 88 mil iraquianos morreram na guerra desde 2005. Folha Online, 24 abr. 2009. Disponível em <http://www1.folha.uol.com.br/folha/mundo/ult94u555662.shtml> Acesso em 30 mai. 2009.

103 CHOMSKY, Noam. 11 de setembro. p. 51.
} 


\subsection{Alguns Comentários Acerca da Política Externa Norte-Americana}

Os atentados ao World Trade Center e ao Pentágono iniciaram uma fase no cenário mundial jamais vista. Levaram, como já foi frisado, o então presidente dos Estados Unidos, George W. Bush, a decretar a famosa "guerra ao terrorismo" e declarar a existência de um "eixo do mal" 104 , do qual fariam parte os países apoiadores ou patrocinadores do terrorismo internacional, quais sejam, Irã, Iraque e Coréia do Norte, mais tarde acrescidos de Cuba e Venezuela ${ }^{105}$, que representariam uma "grave ameaça” à paz e à segurança mundiais.

Tais eventos dotaram os EUA e outras potências de legitimidade para realizar uma série de ações, dentre elas, as ofensivas militares, e serviram como pretexto para dar continuidade ao que Dornelles chamou de "guerra imperial permanente". ${ }^{106}$

Em setembro de 2002, foi anunciada a Doutrina de Segurança Nacional da administração de Bush, que previa uma série de estratégias a serem adotadas, em especial a invasão do Iraque. A implantação da Doutrina se deu automaticamente, sem consulta a nenhuma instância internacional e sem nenhuma intervenção, nem mesmo do Conselho de Segurança da ONU. ${ }^{107}$

Dornelles aponta que a guerra não termina com a invasão do Iraque. A lógica da "guerra infinita" 108 do governo norte-americano, sobretudo da administração de Bush, é, como o nome diz, a da continuidade da guerra no

\footnotetext{
${ }^{104}$ V. nota 75.

${ }^{105}$ DORNELLES, João Ricardo W. Op. cit. p. 6.

${ }^{106}$ Ibid. p. 1.

${ }^{107}$ Ibid. p. 6.

${ }^{108}$ Ibid. p. 1.
} 
mundo todo, vigiando e, se necessário, invadindo as nações que ofereçam perigo aos interesses dos Estados Unidos. ${ }^{109}$

Até porque numa "guerra contra o terrorismo", ou pior, numa "guerra ao terror", fica difícil, se não impossível, se definir quando ela acaba e quem é o vencedor. Contra quem exatamente se está lutando? Quem é o alvo concreto? Carmen Lawrence, professora do Instituto de Estudos Avançados da University of Western Australia, adverte que terrorismo é um método de guerra e não um ator. Não se pode travar uma guerra contra um método. A autora continua, citando Ronald Spiers:

"But how do you win a war against a tool that like war itself, is a method of carrying on politics by other means? A 'war on terrorism' is a war without end in sight, without an exit strategy, with enemies specified not by their aims but by their tactics. Relying principally on military means is like trying to eliminate a cloud of mosquitoes with a machine gun."110

Para Lawrence, o nome "guerra ao terrorismo" foi uma escolha feita cuidadosamente pelo governo norte-americano para obter máxima vantagem política, pois uma nação em guerra apóia muito mais facilmente o seu governo, sem muito questionamento, além de que a guerra pode servir de justificativa para praticamente qualquer situação, até mesmo para a completa violação de direitos humanos, como foi o caso da Baía de Guantánamo. $^{111}$

A autora adiciona que só seria possível acabar com o terrorismo lidando com as verdadeiras causas que o motivam, que geralmente dizem respeito à contestação da opressão. E referindo-se novamente a Spiers, afirma que,

\footnotetext{
${ }^{109}$ Ibid. p. 7.
}

110 LAWRENCE, Carmen. Fear of Annihilation. Disponível em <http://www.albany.uwa.edu.au/pdf/Lawrence\%20Fear\%20of\%20Annihilation.pdf $>$. Acesso em 21 mai. 2009. p. 6.

${ }^{111}$ Ibid. p. 5. 
"[i]n truth the misery and poverty, the oppression, injustice and despair in which most terrorism is spawned and simmers can only be overcome through protracted political, economic and social efforts on the part of the whole international community." $" 112$

Assim, verifica-se que combater o terrorismo com violência não é uma solução razoável; nunca funcionará (para este propósito), só causará ainda mais violência, rancor e desejo de vingança. Tal constatação vem a calhar com o entendimento de que, na verdade, a "guerra ao terror" não tem a intenção de acabar com o terror. Mas é um pretexto para se continuar a prática de guerra e contribuir para manter a posição de dominação dos países centrais, particularmente os EUA, em relação aos demais.

Neste sentido, observa Dornelles que:

"As ações terroristas de 11 de setembro foram a reação a um longo processo de práticas imperialistas, violentas e arbitrárias contra diversos povos do mundo e serviram como o pretexto adequado para a aplicação das medidas de controle social penal global, abrindo a possibilidade para que o Império finque os pés sobre a bacia petrolífera da Ásia Central, ocupe militarmente o Golfo Pérsico, intervenha na região Andina e na Amazônia. Possibilitou a decretação de pacotes de medidas domésticas e internacionais de luta contra o terrorismo, o que não se restringe aos atos violentos ou de terror, mas quaisquer formas de ação contra a hegemonia liberal.",

Desta maneira, a guerra é necessária, de tempos em tempos, ou, permanentemente, como ressalta Dornelles, vez que desempenha papel fundamental no mercado da indústria militar, que movimenta milhões de dólares por ano. Os Estados Unidos possuem a maior indústria bélica do mundo, o que explica, em parte, o seu contínuo interesse em fomentar e incentivar conflitos pelo globo.

\footnotetext{
${ }^{112}$ Apud Carmen Lawrence. Ibid. p. 6.

${ }^{113}$ DORNELLES, João Ricardo W. Op cit. p. 18.
} 
A indústria militar não apenas tem a habilidade de gerar e acumular capital, como também de impulsionar o desenvolvimento e a pesquisa tecnológica. $^{114}$

Para legitimar todas essas práticas e a postura dos detentores do poder, sobretudo dos Estados Unidos, é necessário, como já foi visto, intensa e constante manipulação ideológica. É imprescindível se manter em funcionamento, ininterruptamente, mecanismos de controle social para conter os insatisfeitos e manter a ordem das coisas ${ }^{115}$, tendo em vista que o projeto capitalista-neoliberal não vislumbra toda a população mundial e não possui capacidade de oferecer emprego e renda para todos, apenas para uma restrita minoria, relegando a esmagadora maioria à exclusão. Quem vai contra esta realidade e a posição hegemônica dos dominantes deve ser eliminado. Passa a ser visto como inimigo, que deve ser combatido, não raro, sob a alegação de defesa da justiça, da segurança, da decência e dos direitos humanos.

O controle social é exercido de várias formas diferentes, como através do sistema punitivo, de mecanismos como o eficientismo penal ${ }^{116}$, da disseminação e manipulação do medo social (como já explorado no primeiro capítulo do presente trabalho), dentre outros; sendo que este último constitui uma ferramenta de dominação extremamente eficaz.

No plano internacional, a lógica da guerra contribui neste processo e, de acordo com Dornelles, "introduz o eficientismo penal nas relações internacionais através da criminalização dos movimentos sociais globais contra-hegemônicos, definindo-os como inimigos da ordem global (neoliberal) e cúmplices do terrorismo."

\footnotetext{
${ }^{114}$ Ibid. p. 12.

${ }^{115}$ DORNELLES, João Ricardo W. Conflito e Segurança: Entre pombos e falcões. Rio de Janeiro: Editora Lumen, 2008. p. 21.

${ }^{116}$ Ibid. p. 41-47.

${ }^{117}$ DORNELLES, João Ricardo W. Guerra Imperial Permanente versus Direitos Humanos. p. 16.
} 
Como efeito, a nova ordem imperial dos Estados Unidos, iniciada em 1991, se funda no "pacto de guerra", no qual, "quem não está a favor dos Estados Unidos, faz o jogo dos terroristas". ${ }^{118}$ Não há alternativa. Deste modo,

“[a] política externa norte-americana impõe a derrota do Direito Internacional e introduz a lógica do Eficientismo Penal nas relações internacionais através das ações 'punitivas' contra todos (indivíduos, nações, Estados, movimentos, religiões, etc.) que sejam considerados uma ameaça à ordem hegemônica imperial - genericamente classificados como terroristas." 119

Pode-se dizer que as guerras no Iraque e no Afeganistão, travadas no âmbito da "guerra ao terrorismo", fazem parte deste contexto. Após mais de seis anos de duração, a guerra do Iraque esta se exaurindo ${ }^{120}$, com o anúncio da retirada das tropas americanas e internacionais do território iraquiano e a aparente "democracia" imposta pela guerra. Dentro desta doutrina da guerra contínua, que rege a política externa norte-americana, o Iraque sai de cena, mas o Afeganistão está ganhando novamente destaque. ${ }^{121}$

Segundo Immanuel Wallerstein ${ }^{122}$, o Afeganistão faz parte, desde o século XIX, do "grande jogo" entre a Rússia e a Grã-Bretanha, atualmente sucedida pelos Estados Unidos.

O Paquistão tem interesse em manter o Afeganistão como um vizinho amigável, de forma que a Índia, a Rússia, os Estados Unidos e o Irã

${ }^{118}$ Ibid.p. 4.

${ }^{119}$ DORNELLES, João Ricardo W. Ibid. p. 5.

${ }^{120}$ WALLERSTEIN, Immanuel. Como a Guerra do Iraque vai acabar. Fernand Braudel Center, Binghamton University, 01 jun. 2008. Disponível em 〈http://fbc.binghamton.edu/commentr.htm〉. Acesso em 28 mai. 2009.

${ }^{121}$ WALLERSTEIN, Immanuel. Afeganistão: bancos de areia na rota do presidente Obama. Fernand Braudel Center, Binghamton University, 01 jun. 2008. Disponível em <http://fbc.binghamton.edu/commentr.htm〉. Acesso em 28 mai. 2009.

${ }^{122}$ Pesquisador sênior do Departamento de Sociologia da Yale University e diretor do Fernand Braudel Center for the Study of Economies, Historical Systems, and Civilizations da Binghamton University. 
não tenham interesse em dominá-lo. E por isto, de certa forma, apoia os Talibãs do Afeganistão. Estes, por sua vez, apoiam a Al-Qaeda de Osama Bin Laden. ${ }^{123}$

Em represália aos atentados de 11 de setembro, os Estados Unidos, juntamente com o Reino Unido, o Canadá e a Austrália, contando com o apoio de afegãos revoltosos contra a Al-Qaeda e o Talibã, invadiram o Afeganistão em 7 de outubro de 2001. Foram atingidos alvos estratégicos e os talibãs formam expulsos do poder. O governo vigente foi substituído e centenas de presos foram enviados à prisão de Guantánamo. As lutas prosseguem até hoje e o país ainda se encontra ocupado pelos Estados Unidos e pelas forças aliadas da OTAN.

As atenções parecem estar se voltando uma vez mais ao Afeganistão, e também ao Paquistão, especialmente, depois que o presidente dos Estados Unidos, Barack Obama, prometeu destruir a Al-Qaeda. A questão Afeganistão - Paquistão, referida pela Casa Branca e divulgada pela imprensa como $A F-P A K^{124}$, tem ganhado relevância, por conta da nova ênfase dada à "guerra ao terror". Com a mudança do discurso da guerra do Iraque, apregoada por George W. Bush, para a $A F-P A K$, anunciada por Obama, novos cenários e conflitos poderão surgir.

\footnotetext{
${ }^{123}$ WALLERSTEIN, Immanuel. Af-Pak: Obama's War. Fernand Braudel Center, Binghamton University, 01 abr.2009. Disponível em < http://www.binghamton.edu/fbc/254en.htm>. Acesso em 28 mai. 2009.

${ }^{124}$ Ibid.
} 


\section{A PRISÃO DE GUANTÁNAMO}

"Atravessei uma experiência que nunca pensei encontrar nos meus piores pesadelos. [...] Tenho a dizer, com maior tristeza do que fúria, que muitos foram cúmplices com os horrores que passei nos últimos sete anos".

Binyam Mohamed, ex-detento de Guantánamo, transferido para a Inglaterra em fev. de 2009.

\subsection{A Origem da Prisão de Guantánamo}

A história de Guantánamo remonta ao início do século XX, quando os Estados Unidos arrendaram perpetuamente a Baía de Guantánamo, na municipalidade de Guantánamo, em Cuba, para que a região se transformasse em uma estação de mineração e base naval. Segundo a publicação The History of Guantánamo Bay 1494-1964 $4^{125}$, em 1903, a área foi arrendada por US\$ 2.000 (dois mil dólares) em moedas de ouro. Em 1934, o valor foi revisto para o equivalente a US\$ 4.085 (quatro mil e oitenta e cinco dólares) por ano. Atualmente o governo de Cuba se recusa a descontar os cheques recebidos do governo dos Estados Unidos, pois, há muito tempo quer retomar a área e defende o fechamento da Base Naval. Entretanto, segundo os termos e condições estipulados no acordo original, o mesmo só poderia ser rescindido se ambas as partes concordassem, e os Estados Unidos não concordam.

A prisão militar de Guantánamo tornou-se famosa em 2002 por abrigar os "suspeitos" de ligação com o Talibã ${ }^{126}$ ou com a Al-Qaeda ${ }^{127}$,

\footnotetext{
${ }^{125}$ MURPHY, M.E.. The History of Guantánamo Bay 1494-1964. Rear Admiral, U.S. Navy, U.S. Naval Base Guantánamo Bay, 5 Jan. 1953. Disponível em $<$ http://www.cnic.navy.mil/Guantánamo/index.htm〉. Acesso em 30 de maio de 2009.

${ }^{126}$ O Talibã ou Taliban é um grupo político que atua no Afeganistão e no Paquistão. Teve origem nas tribos que vivem na fronteira entre esses dois países e formou-se em 1994, após a ocupação soviética do Afeganistão (que durou de 1979 a 1989) e durante o governo dos mujahedins. KAKAR, Kawun. An Introduction of the Taliban. Institute for Afghan Studies, outono 2002.
} 
que foram capturados no Afeganistão e no Iraque no âmbito da chamada "Guerra ao Terror".

\subsection{Os prisioneiros de Guantánamo}

Segundo os números da base de dados interativa sobre os prisioneiros de Guantánamo, The Guantánamo Docket ${ }^{\mathbf{1 2 8}}$ elaborada pelo The New York Times, foram registradas (detidas) 779 pessoas na Prisão de Guantánamo, destas, 544 foram transferidas, 6 morreram (suicídio) e 229 ainda se encontram na prisão. A pesquisa abrange de janeiro de 2002 até maio de 2009 (ver tabelas no Anexo I). ${ }^{129}$

Quanto à procedência dos prisioneiros, grande parte dos "suspeitos" foram capturados na invasão do Afeganistão; outros foram enviados por vários países, com base em suspeita de participação em atentados terroristas. Dos 544 prisioneiros transferidos, 11 não tiveram o seu destino identificado e 533 foram enviados para 39 países diferentes ou para serem libertos ou para serem julgados. ${ }^{130}$ Até o final de maio de 2009, somente

\footnotetext{
Disponível em <http://www.institute-for-afghanstudies.org/AFGHAN\%20CONFLICT/TALIBAN/intro_kakar.htm>. Acesso em 15 abr.2009.

${ }^{127}$ A Al-Qaeda é composta por indivíduos que atuam globalmente. Tem ideologia distinta do Talibã. Eventualmente, os dois grupos (Talibã e Al-quaeda) se unem e cooperam nas questões de logística, armas e dinheiro. Osama Bin Laden, um dos fundadores da Al-Qaeda, quando foi expulso de vários países, foi acolhido pelo Talibã no Afeganistão. EREDIA, Talita. Al-Qaeda se transforma em "franquia" ideológica. O Estadão, 01 set.2008. Disponível em $<$ http://www.estadao.com.br/noticias/internacional,al-qaeda-se-transforma-em-franquiaideologica,239818,0.htm>. Acesso em 28 de abr.2009.

128 THE NEW YORK TIMES. The Guantánamo Docket. Disponível em http://projects.nytimes.com/Guantánamo. Acesso em 01 jun.2009.

${ }^{129}$ Estão disponíveis as seguintes tabelas: Tabela 01- Prisioneiros transferidos da Prisão de Guantánamo (Cuba) para outros países (até 01 de Junho de 2009); Tabela 02 - Prisioneiros remanescentes na Prisão de Guantánamo (Cuba) (até 01 de Junho de 2009); Tabela 03 Prisioneiros mortos na Prisão de Guantánamo (2002 até 01 de junho de 2009).

${ }^{130}$ Afeganistão, Albânia, Alemanha, Algéria, Arábia Saudita, Austrália, Bahrain, Bangladesh, Bélgica, Bermudas, Bósnia e Herzegovina, Cazaquistão, Chade, Dinamarca, Egito, Emirados Arabes, Espanha, Estados Unidos, França, Iêmen, Irã, Iraque, Jordânia, Kuwait, Líbia, Maldivas, Marrocos, Mauritânia, Paquistão, Qatar, Reino Unido, Rússia, Somália, Sudão, Suécia, Tajiquistão, Tunísia, Turquia e Uganda. THE NEW YORK TIMES. The Guantánamo Docket.
} 
vinte prisioneiros ${ }^{131}$ haviam sido indiciados por crimes de guerra e apenas três (dentre os 779 presos) tinham sido julgados, dois deles condenados (David Hicks e Salim Ahmed Hamdan), e o terceiro (Omar Khadr) ainda permanece em Guantánamo.

David Hicks ${ }^{132}$, cidadão australiano, foi capturado no Afeganistão em dezembro de 2001. Foi o primeiro suspeito de terrorismo a ser acusado e julgado nos novos tribunais especiais de Guantánamo, declarou-se culpado e foi condenado a 7 anos de prisão, em 26 de março de 2007. Como já havia ficado quase 6 anos em Guantánamo, foi transferido para a prisão Yatala Labour, em Adelaide, no sul da Austrália. Teve 9 meses da sentença suspensos, sendo libertado em dezembro de 2007.

Salim Ahmed Hamdan ${ }^{133}$, iemenita, ex-motorista de Osama Bin Laden, capturado em novembro de 2001 no Afeganistão, foi acusado de ter ligações com a cúpula da Al-Quaeda e de ter sido flagrado com dois mísseis terra-ar dentro do seu carro. O réu se declarou inocente, e a defesa alegou que ele não era membro da Al-Qaeda, sendo apenas um motorista que precisava do salário mensal de 200 dólares. No entanto, foi condenado, em 7 de agosto de 2008, a 66 meses (5 anos e meio) de prisão pelo crime de "apoio material ao terrorismo". Foi julgado por um Tribunal Militar americano de Guantánamo, composto por seis oficiais militares, em que o promotor havia pedido uma pena de "no mínimo 30 anos". Foi o primeiro

\footnotetext{
${ }^{131}$ AFP France Presse. Guantánamo, símbolo dos excessos da "luta contra o terrorismo" de Bush. 21 jan.2009. Disponível em http://www.abril.com.br/noticias/mundo/Guantánamo-simboloexcessos-luta-terrorismo-bush-243529.shtml. Acesso em 20 abr. 2009.

${ }^{132}$ BBC BRASIL. Guantánamo: Único condenado por terrorismo é solto. O Estadão, 29 dez. 2007. Disponível em http://www.estadao.com.br/noticias/geral,Guantánamo-unico-condenadopor-terrorismo-e-solto,102319,0.htm. Acesso em 15 abr. 2009.

${ }^{133}$ AFP France Presse. Tribunal de Guantánamo condena motorista de Bin Laden a 5,5 anos. G1 Globo, 07 ago.2008. Disponível em http://g1.globo.com/Noticias/Mundo/0,,MUL715688-5602,00TRIBUNAL+DE+GUANTÁNAMO+CONDENA+MOTORISTA+DE+BIN+LADEN+A+ANOS. html. Acesso em 15 abr. 2009
} 
julgamento por crimes de guerra realizado por um tribunal militar norteamericano desde o final da Segunda Guerra Mundial.

Omar Khadr, cidadão canadense, foi preso no Afeganistão em 2002, quando tinha apenas 15 anos, sob a alegação de que teria causado a morte a um soldado norte-americano durante um combate. Teve seu processo suspenso em razão da decisão do presidente Barack Obama em 21 de janeiro de $2009{ }^{134}$ e ainda se encontra em Guantánamo, após 7 anos de detenção, a espera de um julgamento.

A Anistia Internacional, referindo-se ao caso acima, denunciou a indiferença por parte do governo do Canadá, país de origem de Khadr:

"O governo (canadense) continua se recusando a intervir junto às autoridades dos EUA no caso do cidadão canadense Omar Khadr, preso no Afeganistão quando tinha 15 anos e mantido na base de Guantánamo por mais de seis anos."135

Também chamou a atenção internacional o caso dos 17 chineses da etnia uigur, que estão presos há sete anos. A detenção deles foi considerada ilegal, tendo sido ordenada a libertação imediata. Foi também reconhecido que os mesmos não poderiam ser devolvidos à China, pois enfrentariam perigo de tortura e execução. Não foi encontrado um país disposto a aceitálos e tampouco poderiam permancer em território norte-americano de modo que ainda estão em Guantánamo. A Anistia Internacional expressa preocupação e apela pela libertação imediata dos mesmos em território americano. $^{136}$

\footnotetext{
${ }^{134}$ O ESTADÃO. A pedido de Obama, Justiça congela $1^{\circ}$ processo de Guantánamo. O Estadão Internacional, 21 jan. 2009. Disponível em http://www.estadao.com.br/noticias/internacional,apedido-de-obama-justica-congela-1-processo-de-Guantánamo,310640,0.htm. Acesso em 15 abr. 2009.

135 AMNESTY International. Amnesty International Report 2009: State of the World's Human Rights. 30 mai.2009. Disponível (em português) em < http://report2009.amnesty.org/press-área/ptbr/download-report>. Acesso em 31 mai. 2009. p. 116.

${ }^{136}$ ANISTIA INTERNACIONAL. EUA: Preocupação Jurídica - 17 detidos uigur reclusos em Guantánamo. Anistia Internacional, 7 mai. 2009. Disponível em <http://www.br.amnesty.org/?q=note/304. Acesso em 23 mai. 2009.
} 
Alguns dos detentos apreendidos no Afeganistão, levados para Guantánamo e depois transferidos para serem processados pelo governo afegão, foram julgados, mas sem que se cumprissem as normas nacionais ou internacionais para julgamentos justos. Segundo a Anistia Internacional, estes julgamentos foram prejudicados por falhas graves que incluíam a ausência de advogados de defesa e prazo insuficiente para preparar a mesma, o uso de confissões obtidas mediante tortura ou outros maus-tratos e a negação do direito de examinar as provas e confrontar as testemunhas.

\subsection{Tratamento dos prisioneiros}

De acordo com o Informe 2009 da Anistia Internacional ${ }^{137}$, houve inúmeras denúncias dos abusos praticados na Prisão de Guantánamo em 2008. A condição dos prisioneiros de Guantánamo é desumana e viola flagrantemente todos os estatutos de direitos humanos vigentes.

Como será brevemente descrito a seguir, a tortura é, ainda hoje, uma constante no dia-a-dia dos presos. A estrutura da prisão, a maneira como são tratados os encarcerados e as regras de funcionamento foram planejadas de modo a privilegiar e a facilitar a obtenção de informações dos detentos, de modo que todo o sistema de Guantánamo gira em torno desta finalidade. $^{138}$

De acordo com um estudo realizado pelo Centro de Direitos Humanos da University of California, Berkeley, a entrevista dada pelo exvice-presidente dos Estados Unidos, Dick Cheney, no programa Meet the

\footnotetext{
${ }^{137}$ AMNESTY International. Op. cit. p. 19.

${ }^{138}$ FLETCHER, Laurel; STOVER, Eric. Guantánamo and its aftermath: U.S detention and interrogation practices and their impact on former detainees. Berkeley: Human Rights Center, University of California Berkeley, 2008. p. 7-9.
} 
Press, do canal CBS, poucos dias após os atentados de 11 de setembro, ilustra de forma clara este objetivo:

"We'll have to work sort of the dark side... We've got to spend time in the shadows in the intelligence world. A lot of what needs to be done here will have to be done quietly, without any discussion, using sources and methods that are available to our intelligence agencies - if we're going to be successful. That's the world these folks operate in. And, so it's going to be vital for us to use any means at our disposal basically, to achieve our objectives." 139

O primeiro passo em direção a este projeto foi a criação de um novo paradigma para a "guerra ao terror" pelo então presidente George W. Bush, que autorizou a implantação de um sistema novo e ad hoc de detenção e de "técnicas de interrogação avançadas" ${ }^{140}$, que operaria fora de qualquer sistema jurídico existente. ${ }^{141}$ Daí a escolha da prisão de Guantánamo para receber os "suspeitos" capturados. As autoridades norte-americanas se preocuparam em escolher um local que se encontrasse fora do território dos Estados Unidos, onde, portanto, as garantias legais e constitucionais americanas não se aplicariam, abrindo, assim, o caminho para a realização de qualquer tipo de interrogatório, tão longos e tão freqüientes quanto fosse necessário, e sob as condições que fossem mais convenientes.

Com relação aos interrogatórios, vale fazer menção a um dos casos descritos em publicação da ONG de direitos humanos portuguesa, Humana Global, que exemplifica as violações que são cometidas:

“[...] um ex-prisioneiro em Guantánamo, de nome Walid al Qadasi, descreve-nos que, em Kabul, os prisioneiros apelidaram a primeira noite de interrogatórios como sendo a 'noite negra', podendo todos nós facilmente adivinhar por que motivos foi desta forma apelidada... Nessa noite, Walid afiança que lhes foram cortadas as suas vestes, ficando todos os prisioneiros nus, foram-lhes tiradas fotografias nesse estado, muitas vezes em poses pornográficas, junto a mulheressoldado, com requintes de sadismo e malvadez, atando arames a partes do corpo, para além de que '[...] algemaram as nossas mãos atrás das nossas costas,

\footnotetext{
${ }^{139}$ Ibid., p. 7.

140 "Enhanced interrogation techniques".

${ }^{141}$ Ibid., p. 7.
} 
vendaram os nossos olhos e começaram a interrogar-nos [...], ameaçaram-me de morte, acusando-me de pertencer à Al-Qaeda". ${ }^{142}$

Além de haver completa liberdade para interrogar os presos, em um local fora do alcance de qualquer ordenamento jurídico, seria possível, também, manter indivíduos presos por tempo indeterminado ${ }^{143}$.

Os presos tampouco são protegidos pelas Convenções de Genebra, que prevêem direitos para os prisioneiros de guerra, inclusive as condições mínimas de encarceramento, pois, para os Estados Unidos, não se tratam de prisioneiros de guerra. Em 25 de janeiro de 2002, Alberto Gonzalez, exSecretário de Justiça dos Estados Unidos, enviou relatório ao presidente Bush recomendando que negasse explicitamente a proteção da Terceira Convenção de Genebra a todos os prisioneiros do Talibã e da Al-Qaeda, para "preservar a flexibilidade" e diminuir o risco de que oficiais do governo viessem a ser processados por crimes de guerra. Nos dias que se seguiram, George Bush formalmente acatou a recomendação de Gonzalez e declarou que os "suspeitos" apreendidos não seriam prisioneiros de guerra, mas "inimigos combatentes ilegais", categoria não reconhecida pelas referidas Convenções. ${ }^{144}$

No tocante às condições de encarceramento em Guantánamo, o relatório do Center for Constitutional Rights, de fevereiro de $2009^{145}$, não é nada otimista. De acordo com a publicação, a maioria dos detidos em Guantánamo é mantida em prisão solitária. Há três campos que servem este

\footnotetext{
${ }^{142}$ OLIVEIRA, Filipe. Refugiados e Direitos Humanos nas Prisões. In: HUMANA GLOBAL. $A$ Organização das Nações Unidas. Coimbra: Associação para a Promoção dos Direitos Humanos, da Cultura e do Desenvolvimento, 2007. p. 265

${ }^{143}$ FLETCHER, Laurel; STOVER, Eric. Op. cit. p. 8-9.

${ }^{144}$ Ibid., p. 8.

${ }^{145}$ CENTER for Constitutional Rights. Current conditions of confinement at Guantánamo. New York: CCRjustice, 2009. Disponível em <http://ccrjustice.org/learn-more/reports/currentconditions-confinement-guantanamo>. Acesso em 20 mai. 2009.
} 
propósito: Campos 5, 6 e Echo. Oficiais militares alegam que os dois primeiros se destinam apenas aos prisioneiros "desobedientes"; contudo, não é o que se vê na prática. Dado que a maior área coletiva da base é o Campo 4, que possui apenas 80 camas, todos os outros são obrigados a permanecer nos três campos acima. Muitos dos indivíduos que já receberam autorização para serem soltos - mas ainda não foram porque não há como transferi-los de maneira segura de volta para seus países de origem - são mantidos nestes campos. Os militares não admitem tratar-se de prisão solitária, mas de celas com "mais privacidade" ou "de ocupação individual". O que é corroborado pelo atual governo de Barack Obama. ${ }^{146}$

Dois depoimentos ilustram bem a contradição: "It's kind of like having their own apartment." (Guarda do Campo 6). "I am in my tomb." (Abdeli Feghoul, prisioneiro do Campo 6, autorizado a sair em liberdade desde 2006). ${ }^{147}$

Malgrado as afirmações oficiais, a permanência em celas isoladas, pequenas, feitas de aço e concreto, sem praticamente nenhum contato humano, durante anos, surte efeitos cruéis e degradantes nos prisioneiros. Eles permanecem ao menos 20 horas por dia dentro da cela. É permitido ficar, no máximo, de duas a quatro horas por dia em uma cela externa, o que se denomina de "recreação" e é destinado aos presos "obedientes". Alguns deles relatam que quando tentaram praticar algum exercício físico durante a "recreação", foram levados de volta às suas celas imediatamente. Se os guardas considerarem que algum prisioneiro cometeu alguma desobediência, este poderá ficar trancafiado e perder o direito à "recreação". Não devolver a bandeja de comida prontamente ou fazê-lo de má-vontade pode ser considerado como violação, por exemplo.

\footnotetext{
146 Ibid. p. 4-5.

${ }^{147}$ Ibid. P. 4.
} 
Sob a alegação de que não há espaço para que todos gozem da "recreação" durante o dia, ela pode se dar em qualquer horário, mesmo durante a madrugada, quando os guardas acordam os detentos abruptamente para que saiam de suas celas. Como alguns preferem não ir para poderem dormir, acabam ficando vários dias e até semanas sem contato com o ar fresco.

Os presos são rotineiramente maltratados pelos guardas e, especialmente, nos campos 5, 6 e Echo, vivem com medo de sofrer novas agressões físicas. A punição aos "desobedientes" é severa e conta com o apoio da Força de Reação imediata ${ }^{148}$, que permanece sempre em vigilância, pronta para atuar quando é chamada. Por vezes, ela atua de repente, sem dar explicação, mesmo na ausência de infração por parte do preso. $^{149}$

O relatório descreve que um dos presos, Yasin Ismael, em janeiro de 2009, foi colocado em uma das "celas" externas - que mais parecem jaulas para a "recreação". Como a "cela" em que foi posto encontrava-se inteiramente na sombra, Yasin pediu ao guarda se poderia ser removido para outra, ao lado, onde batia sol. O guarda respondeu que "[y]ou're not allowed to see the Sun”. Yasin, então, atirou um sapato contra a parede interna da "jaula", que, por óbvio, bateu e caiu no chão na parte de dentro. Entretanto, os guardas acusaram-no de agressão e violência e abandonaramno lá. Após algum tempo, Yasin pegou no sono no chão da "cela" e, horas depois, foi acordado pela Força de Reação Imediata, que o algemou, espancou e trancou seu nariz e boca até que quase sufocasse. Ao levá-lo de volta para a sua cela, um guarda urinou na sua cabeça. A lesão foi tão

\footnotetext{
${ }^{148}$ Immediante Reaction Force (IRF). Ibid. p. 7-9.

${ }^{149}$ Ibid. p. 8.
} 
profunda que os ouvidos de Yasin começaram a sangrar, deixando manchas em seu travesseiro. ${ }^{150}$

A comida é entregue por uma pequena abertura na porta da cela e cada um faz suas refeições sozinho. Pasta dental, escova dental, sabonete, desodorante, lençóis e cobertores são considerados como "privilégios" e podem ser confiscados a qualquer momento.

O Campo 6 não tem nenhuma janela virada para fora e o Campo 5 tem apenas uma janela estreita em cada cela. A iluminação é intensa e as luzes ficam acesas 24 horas por dia no campo 5. Nos demais campos, fica acesa entre 5:00h da manhã e 22:00h e uma luz menos intensa permanece acesa durante à noite.

Muitas vezes, a temperatura dentro das celas é muito fria, o que causa problemas de saúde como reumatismo (especialmente para os indivíduos que têm seus colchonetes confiscados como castigo para algum ato "infrator"). Se alguém tenta cobrir a saída do ar condicionado de sua cela, no intuito de aumentar a temperatura para um nível mais tolerável, é punido.

Como forma de oposição às condições a que são submetidos, a greve de fome tem se tornado recorrente entre os presos, que passaram a receber alimentação artificial contra a sua vontade, mediante o uso da força, tendo os quatro membros atados a uma cama e lá permanecendo por horas, para evitar que tentem forçar o vômito logo após o procedimento. Como ficam dias sem comer, muitas vezes, são forçados a receber alimento em quantidades muito maiores do que o estômago poderia comportar, ocasionando dores, vômitos e mal-estar. Alguns prisioneiros relatam que a sonda, que é inserida à força através do nariz até chegar ao estômago, sem

${ }^{150}$ Ibid. p. 8. 
nenhuma anestesia, é comumente re-utilizada em outros indivíduos sem a devida esterilização. ${ }^{151}$

Os depoimentos de alguns presos expressam a gravidade da situação:

"I'm in despair right now and I don't know what to do. I'm going crazy." (Muhammed Khan Tumani, detido aos 17 anos). ${ }^{152}$

“As I told you, we are in very bad condition, suffering from aggression, beating and IRF [Immediate Reaction Force] team, as well as the inability to sleep except for a few hours. Soldiers here are on a high alert state and if one of us dares to leave his cell and comes back without any harm, he is considered as a man who survived an inevitable danger." (Detento do Campo 6 em janeiro de 2009). ${ }^{153}$

Pode-se ter uma idéia de outros casos através da matéria produzida pela AFP France Presse, em 10 de janeiro de 2007, com base nos depoimentos de 26 agentes que atuam ou atuaram na prisão de Guantánamo. Estes agentes responderam a um questionário do FBI que buscava descobrir se os agentes haviam testemunhado maus-tratos infringidos aos presos. A título de exemplo, citam-se alguns dos fatos descritos ${ }^{154}$ :

"Um agente descreveu o interrogatório de um prisioneiro em outubro de 2003: privado de sono, transferido de cela em cela, algemado, foi questionado durante horas. No segundo dia, um capitão dos Marines se agachou sobre o Alcorão em frente a ele. No terceiro dia, foi confrontado a um cão agressivo, da raça pastor alemão".

"Um outro agente conta que, em outubro de 2002, um agente civil do Exército foi procurá-lo rindo para lhe mostrar sua obra: ele tinha envolvido com fita adesiva a cabeça de um prisioneiro barbudo, porque este último não parava de se curvar sobre o Alcorão".

${ }^{151}$ Ibid. p. 8-12.

${ }^{152}$ Ibid. p. 9.

${ }^{153}$ Ibid. p. 7.

${ }^{154}$ AFP Agence France-Presse. Em cinco anos Guantánamo arruinou centenas de vidas e a $\begin{array}{llllcl}\text { reputaço dos } & \text { EUA. } & 10 & \text { jan.2007. Disponível } & \text { em }\end{array}$ http://g1.globo.com/Noticias/Mundo/0,,AA1415272-5602,00.html. Acesso em 28 abr. 2009. 
"O terceiro agente conta que discutiu, no verão de 2004, com um investigador que se gabou de ter obrigado um prisioneiro a ouvir rock satânico no volume máximo durante horas, e depois se vestiu de padre para batizá-lo”.

"Vários agentes também narraram ter visto prisioneiros algemados no chão às vezes por mais de 24 horas, e com música do tipo rap no máximo volume, a temperaturas extremas. Um prisioneiro foi encontrado quase inconsciente num quarto a quase $40^{\circ} \mathrm{C}$ de temperatura, com um monte de cabelos do lado, que provavelmente ele arrancou de desespero durante a noite".

Os casos de Murat Kurnaz, libertado após cinco anos de prisão e de Mustapha Ait Idir, libertado após sete anos de prisão, totalmente inocentado, em dezembro de 2008, também servem como ilustração do tratamento dado aos prisioneiros.

Murat Kurnaz em declaração para a Comissão de Relações Exteriores do Senado Americano, em 2008.

"Nada fiz e fui tratado como um monstro[...]."

"Fui privado de sono, isolado, submetido a humilhações religiosas e sexuais, golpeado incontáveis vezes, interrogado sempre e sempre" e deixado à mercê dos carcereiros.

"Não havia lei em Guantánamo". ${ }^{155}$

Mustapha Ait Idir, em declaração à Agence France-Presse, após ser libertado, em dezembro de 2008.

"Ninguém pode imaginar como é terrível. Até o diabo não poderia acreditar num local assim tão mau. [...] Os guardas tinham o hábito de vir em grupos de seis ou sete e começavam pulverizando tudo com gás; aí iniciavam, então, as sessões de espancamento." 156

\footnotetext{
155 AFP. "Até o diabo não poderia acreditar em Guantánamo". 05 mai.2009. Disponível em http://g1.globo.com/noticias/mundo/0,,mul714568-5602,00saiba+mais+sobre+os+tribunais+militares+em+Guantánamo.html. Acesso em 22 maio.2009.

${ }^{156}$ AFP. "Até o diabo não poderia acreditar em Guantánamo". 05 mai. 2009. Disponível em http://g1.globo.com/noticias/mundo/0,,mul714568-5602,00-

saiba+mais+sobre+os+tribunais+militares+em+Guantánamo.html. Acesso em 22 maio.2009.
} 
Todo este conjunto de fatores, prolongado por anos, leva os prisioneiros ao desespero, à depressão e à insanidade mental. Muitos deles se encontram visivelmente afetados e alguns advogados relatam que podem notar, a cada encontro com o cliente, a sua rápida degradação, chegando ao ponto de alguns presos nem quererem mais deixar suas celas temendo agressão física por parte dos oficiais. Já houve inúmeras tentativas de suicídio, que denunciam o estado destas pessoas, que deveriam receber tratamento psicológico e psiquiátrico adequado. Em vez disso, os detentos que se flagelam, são punidos severamente pelos guardas, que alegam se tratar de "tentativa de manipulação" por parte dos detentos, o que agrava ainda mais o problema.

\subsection{As Comissões Militares}

Para julgar os prisioneiros, são formadas as comissões militares, ou tribunais militares, que são compostas de cinco a doze oficiais das Forças Armadas norte-americanas e um juiz militar, sendo todos americanos. A condenação se dá com o voto favorável de dois terços da comissão e, nos casos de pena de morte, em que a comissão contém, no mínimo, 12 membros, o voto favorável deve ser unânime. O presidente dos Estados Unidos é quem toma a decisão final a respeito da pena de morte. Essas sessões são abertas à imprensa e organizações nacionais e internacionais, ainda que, em casos de ameaça à segurança ou proteção, o tribunal possa ser fechado. ${ }^{157}$

Os suspeitos estrangeiros podem buscar revisão judicial em tribunais civis. Os estrangeiros presos em Guantánamo estão sujeitos à Lei de Comissões Militares, enquanto os presos norte-americanos estão sujeitos à

${ }^{157}$ BBC BRASIL. Saiba mais sobre os tribunais militares em Guantánamo. 06 ago.2008. Disponível em http://g1.globo.com/Noticias/Mundo/0,,mul714568-5602,00saiba+mais+sobre+os+tribunais+militares+em+Guantánamo.html. Acessado em 22 mai.2009. 
sua própria legislação. Os principais alvos da Lei de Comissões Militares são os suspeitos de terrorismo internacional. O que espanta não é apenas o fato de os americanos estarem em condições mais favoráveis, mas também o de serem os juízes todos americanos e julgarem estrangeiros a partir de uma lei que não os pertence.

Os réus possuem direito a advogado militar e defensor civil, de estar presente no julgamento e de tomar conhecimento das provas contra eles. Contudo, o juiz pode determinar que tais provas apenas sejam mostradas resumidamente ao réu, se entender necessário por questões de segurança ${ }^{158}$. Qualquer tipo de prova pode ser aceita, se o juiz militar determinar que tem valor probatório. Em caso de condenação, dada pela aprovação de apenas dois terços da comissão, o réu pode apelar para uma corte de revisão e então a uma corte civil americana. Ainda que a tortura, em tese, não seja mais permitida, a coerção o é e inclui técnicas como a de simulação de afogamento.

Deste modo, trata-se de um tipo tribunal que julga em condições desfavoráveis aos réus, uma vez que terão uma defesa muito debilitada.

Em meio a tantas injustiças, choca o fato de que, dentre os 229 prisioneiros ainda mantidos em Guantánamo, apenas uma minoria poderá ser julgada pelos tribunais militares. Os outros, por falta de provas, ainda poderão permanecer presos por tempo indeterminado e sem julgamento, ou transferidos para prisões em outros países. ${ }^{159}$

Em junho de 2008, a Suprema Corte Americana decidiu que os detentos de Guantánamo tinham o direito constitucional de contestar, em tribunais federais dos EUA, a legalidade de sua detenção. Até o final de 2008, apenas os casos de oito detentos que contestaram sua detenção como

\footnotetext{
${ }^{158}$ BBC BRASIL. Saiba mais sobre os tribunais militares em Guantánamo. 06 ago.2008. Disponível em http://g1.globo.com/Noticias/Mundo/0,,mul714568-5602,00saiba+mais+sobre+os+tribunais+militares+em+Guantánamo.html. Acessado em 22 mai.2009.

${ }^{159}$ Ibid.
} 
criminosos de guerra em petições de habeas corpus haviam sido decididos. $^{160}$

\subsection{Estado de Exceção}

Guantánamo representa a total violação do Direito internacional dos direitos humanos e do Direito humanitário, construídos com tanto empenho ao longo do século XX. Em nome da segurança, instaurou-se um verdadeiro estado de exceção, em que os indivíduos "suspeitos" de envolvimento com a Al-Qaeda e com o Talibã foram mantidos em uma área fora do alcance de qualquer sistema jurídico ou jurisdição, privados de todas as suas garantias fundamentais.

Estamos diante de uma situação caótica em que estes indivíduos são presos sem acusação formal e mantidos indefinidamente, sem inquérito e sem julgamento, ficando à mercê de funcionários e agentes de inteligência. Os Estados Unidos se recusaram a classificar estes detidos como prisioneiros de guerra, caso em que estariam protegidos pelos direitos assegurados nas Convenções de Genebra ${ }^{161}$. Em vez disso, como já foi dito, atribuíram-lhes o status de "combatentes inimigos", o que significa que não estão cobertos pelas leis internacionais, tampouco pela lei norte-americana, possibilitando a sua retenção por tempo indeterminado e as condições de prisão e técnicas de interrogatório "contraterroristas". Os Estados Unidos vêm tentando justificar a não-observância dos seus próprios preceitos constitucionais e legais aplicáveis a prisioneiros estrangeiros e das regras de Direito internacional dos direitos humanos e de Direito humanitário, com os quais o país se comprometeu juridicamente - como o Pacto dos Direitos

\footnotetext{
${ }^{160}$ AMNESTY International. Op. cit. p.135

${ }^{161}$ AGAMBEN,Giorgio. Estado de Exceção - Homo Sacer, II, 1. p. 14.
} 
Civis e Políticos, a Convenção contra a Tortura e as Convenções de Genebra. $^{162}$

Esta conjuntura foi possibilitada pela "military order" assinada pelo então presidente dos Estados Unidos George W. Bush, em 13 de novembro de 2001, autorizando a prisão por tempo indefinido e o processo perante as comissões militares. O Ato Patriota dos Estados Unidos ${ }^{163}$, de 26 de outubro do mesmo ano permitiu ao Attorney General manter preso o estrangeiro suspeito de oferecer ameaça à segurança nacional dos Estados Unidos, que, no entanto, deve ser expulso ou acusado de algum crime dentro de sete dias. ${ }^{164}$

José María Gómez afirma que Guantánamo faz parte da lógica da "globalização militarizada" em andamento, liderada pelo imperialismo dos Estados Unidos, a qual ganhou força após 11 de setembro. Tal estratégia implica "a legitimação de crescentes espaços de exceção, a guerra preventiva sem ameaça de ataque iminente e a ascensão do 'inimigo absoluto' encarnado na figura desterritorializada do novo terrorista teológico-político". 165

O filósofo italiano Giorgio Agamben afirma que tal ato invalida “todo o estatuto jurídico do indivíduo, produzindo, dessa forma, um ser juridicamente inominável e inclassificável."166

\footnotetext{
162 GÓMEZ, José María. Soberania imperial, espaços de exceção e o campo de Guantánamo: desterritorialização e confinamento na "guerra contra o terror". Contexto Internacional: Revista do Instituto de Relações Internacionais (IRI) da Pontifícia Universidade Católica do Rio de Janeiro PUC-Rio. Rio de Janeiro, vol. 30, no. 2, ago 2008. Disponível em <http://publique.rdc.pucrio.br/contextointernacional/cgi/cgilua.exe/sys/start.htm?infoid=473\&sid=67>. Consulta em 10 mai. 2009. p. 268.

${ }^{163}$ United States Patriot Act.

${ }^{164}$ AGAMBEN, Giorgio. Op. cit. p. 14.

${ }^{165}$ GÓMEZ, José María. Op. cit. p. 269.

${ }^{166}$ AGAMBEN,Giorgio. Op. cit. p. 14.
} 
Agamben trabalha a questão do biopoder, que é a normatização da vida e a consolidação do poder por meio do domínio do corpo. O autor traz o conceito de "vida nua", que seria a vida natural despolitizada. Aos indivíduos eliminados da vida política, restaria tão-somente a vida biológica. ${ }^{167}$ Os prisioneiros de Guantánamo seriam o exemplo máximo disso. Nas palavras do autor, estes indivíduos, são

“objetos de uma pura dominação de fato, de uma detenção indeterminada não só no sentido temporal, mas também quanto à sua própria natureza, porque totalmente fora da lei e do controle judiciário. A única comparação possível é com a situação jurídica dos judeus nos Lager nazistas: juntamente com a cidadania, haviam perdido toda a identidade jurídica, mas conservaram pelo menos a identidade de judeus. Como Judith Butler mostrou claramente, no detainee de Guantánamo a vida nua atinge sua máxima indeterminação". ${ }^{168}$

O estado de exceção se tornou regra na sociedade contemporânea. $\mathrm{Na}$ denominada "guerra civil mundial" 169 em que vivemos, e, mais especificamente na atual "guerra ao terror" e na Prisão de Guantánamo, isto fica evidente. O que geralmente se entende é que o estado de exceção situase no limite entre a política e o Direito, assim como a guerra civil, a insurreição e a resistência, e é, por isso, ambíguo e de difícil definição ${ }^{170}$. O autor enfatiza a relevância da temática do estado de exceção na atualidade e acrescenta que não há uma teoria sobre o assunto no Direito Público, visto que sempre foi um tema desconsiderado na doutrina.

Agamben considera válido retomar o pensamento de Carl Schmitt para auxiliar na compreensão do contexto contemporâneo, ainda que suas

${ }^{167}$ AGAMBEN,Giorgio. Homo Sacer - O Poder Soberano e a Vida Nua I. Belo Horizonte: Editora UFMG, 2002.

168 AGAMBEN,Giorgio. Estado de Exceção - Homo Sacer, II, 1. p. 14.

${ }^{169}$ A expressão "guerra civil mundial” foi usada no mesmo ano - 1963 - por Hannah Arendt, no livro Sobre a Revolução, e por Carl Schmitt, no livro Teoria da Guerilha. AGAMBEN,Giorgio. Estado de Exceção - Homo Sacer, II, 1. p. 13.

${ }^{170}$ Ibid., p. 11. 
idéias tenham sido bastante criticadas. De acordo com o jurista alemão, caberia exclusivamente ao soberano decidir sobre o estado de exceção, e é esta característica que definiria o próprio poder soberano. Ao poder soberano incumbe, em caso de ameaça à unidade política e à ordem, colocar-se fora do sistema jurídico e suspendê-lo provisoriamente, para restabelecer a segurança e criar condições para que o Direito volte a atuar. $^{171}$

Para Agamben, "o estado de exceção apresenta-se como forma legal daquilo que não pode ter forma legal. Por outro lado, se a exceção é o dispositivo original graças ao qual o direito se refere à vida e a inclui em si por meio de sua própria suspensão, uma teoria do estado de exceção é, então, condição preliminar para se definir a relação que liga e, ao mesmo tempo, abandona o vivente ao direito."

Neste sentido, o soberano se situa concomitantemente - e paradoxalmente - dentro e fora do ordenamento jurídico e detém o monopólio da decisão última. Desta maneira, o Estado soberano tem o poder de decidir quem são os inimigos e combatê-los. ${ }^{173}$

Assim, na complexa realidade contemporânea e em sintonia com a globalização - e, portanto, com uma quantidade cada vez maior de problemas e "ameaças" -, o estado de exceção se torna permanente, tendência que se iniciou com os regimes totalitários do séc. XX e permaneceu até hoje ${ }^{174}$. Por meio do estado de exceção, instaura-se a "guerra civil mundial", que possibilita a supressão dos sujeitos e categorias considerados como "inimigos da humanidade".

\footnotetext{
${ }^{171}$ Ibid., p. 11-13.

${ }^{172}$ Ibid., p. 12.

${ }^{173}$ GÓMEZ, José María. Op. cit. p. 282-284.

${ }^{174}$ AGAMBEN,Giorgio. Estado de Exceção-Homo Sacer, II, 1. p. 19.
} 
Nesse diapasão, a detenção indefinida e o horrendo tratamento conferido aos presos nos "campos de concentração" 175 da atualidade representam mecanismos de desumanização, pautados por "um marco racial-étnico identificador e diferenciador de certas populações" ${ }^{176}$, que selecionam

"quem é humano e quem não é, quem merece viver e quem deve morrer, quem vai permanecer detido em razão de uma periculosidade inata e irrevogável. Um mecanismo, portanto, que funciona em um espaço sem lei, a não ser por aquelas ditadas pelo Executivo como sujeito do poder soberano do Estado de suspender a lei ou de fabricá-la em seu próprio benefício. Mesmo quando se trata, em última análise, de um poder soberano que termina por ser exercido por funcionários burocratas que decidem, com critérios incertos e sem nenhuma responsabilidade, se os detentos representam ou não um perigo para a segurança dos EUA. É por isso que a detenção indefinida se converte na figura condensadora e emblemática de uma política antiterrorista baseada na suspensão dos direitos fundamentais, na expansão das vigilâncias e controles e na contínua primazia do Executivo sobre o Legislativo e o Judiciário. Desse modo, manifestam-se uma prática e um ideário hegemônico que fomentam a "desconstitucionalização" e que se baseiam em uma grave ameaça que corrói por dentro a própria democracia liberal, o Estado de Direito e os direitos humanos como garantias de proteção perante o arbítrio estatal."177

A estratégia de segurança dos Estados Unidos representa um enorme retrocesso em relação à fase progressiva pela qual passaram o Direito internacional dos direitos humanos e o Direito humanitário nas últimas seis décadas, caracterizada por estender ao máximo a abrangência da proteção das pessoas contra atos de barbárie, como rege o preâmbulo da Declaração Universal dos Direitos Humanos, além disso,

\footnotetext{
${ }^{175}$ GÓMEZ, José María. Op. cit. 269.

${ }^{176}$ Ibid. p. 286.

${ }^{177}$ Ibid. p. 286-287.
} 
"reafirma a vontade de subtrair certa categoria de não-cidadãos estadunidenses da proteção da lei da guerra e dos direitos humanos e justifica a situação de exceção daqueles que deixa sob completa autoridade discricionária do Executivo e de suas agências especializadas no exercício do poder punitivo do Estado. Não surpreende, então, que "o argumento legal da administração Bush sobre o estatuto dos acusados de terrorismo reflita facetas cruciais da lógica de Carl Schmitt." ${ }^{178}$

Importante frisar que não se está afirmando que não haja perigo de fato de ataques terroristas e que eles não devam ser evitados, mas o que não se pode admitir é que tal ameaça sirva de pretexto para a prática de injustiças e brutalidades, como a prisão desmotivada de inocentes e a prática de tortura e outras crueldades - o que vem ocorrendo nas prisões "de guerra" controladas pelos EUA.

É difícil aceitar que as atrocidades verificadas na prisão de Guantánamo, bem como nas de Abu Ghraib, Bagram e outras, tenham ocorrido em pleno séc. XXI, após, como mencionado, várias décadas de avanço da legislação do Direito internacional dos direitos humanos e sendo que a comunidade internacional é formada, em sua grande maioria, por Estados democráticos. Esta, talvez, seja a constatação mais assustadora - a de que é possível que situações como essa aconteçam nos dias de hoje e ainda sejam encaradas como normais.

Além do mais, uma política que se proponha verdadeiramente a acabar com o terrorismo deve ser implantada juntamente com outras políticas, que visem lidar com as causais reais deste fenômeno - sociais, econômicas, financeiras, culturais, e que, obviamente, observem as regras internacionais de direitos humanos e de Direito humanitário. Se não, restará apenas "a opção do excepcionalismo difuso que a 'guerra contra o

${ }^{178}$ Ibid. p. 288. 
terror' e a figura indeterminada do terrorista como inimigo absoluto

pretendem legitimar" ${ }^{\prime 179}$, de um lado, acarretando um interminável ciclo de violência para conservar a ordem capitalista neoliberal, e, de outro, corroendo, gradativamente, o Estado de Direito e a democracia.

\subsection{Fim de Guantánamo?}

A comunidade internacional, organizações de direitos humanos e a Anistia Internacional estão se movimentanto em torno do assunto. $\mathrm{O}$ Parlamento Europeu, através de seus pronunciamentos deixa a entender que quanto mais acentuada for a pressão internacional destinada a fechar Guantánamo, maior será o risco de exposição a tortura que os prisioneiros poderão sofrer. Os fatos são controversos, mas a intenção de intervenção européia pode ser percebida pelas alegações dadas, em 28 de fevereiro de 2009, pela eurodeputada Sarah Ludford, durante uma sessão organizada pela Comissão das Liberdades Cívicas e pela Subcomissão dos Direitos Humanos:

“[...] alguns [prisioneiros] perdem a razão por viverem em células estreitas de 2,0 x 2,5 metros, sem luz do dia e com uma luz artificial permanente. [...] Chegou o momento da Europa afirmar a sua vontade política de ajudar os EUA a fechar este capítulo vergonhoso da história." 180

Várias entidades e organizações de direitos humanos têm se manifestado sobre o assunto. O relatório elaborado pelo Center For Constitucional Rights faz a seguinte recomendação ao seu final:

\footnotetext{
${ }^{179}$ Ibid. p. 293.

${ }^{180}$ PARLAMENTO EUROPEU. Poderá a Europa acolher os prisioneiros de Guantánamo? 03 mar.2009. Disponível em <http://europarl.europa.eu/side/getDoc.do?pubRef=-//EP//TEXT+IM->. Acesso em 25 mai.2009.
} 
"In the brief interim period while the closure of Guantánamo is being implemented, it is critical that the conditions of detention at Guantánamo be improved. The men held in Campus 5, 6 and Echo desperately need to be moved to facilities with lawful and humane conditions of the confinement. These camps are in violation of the Geneva Conventions, the U.S. Constitution, and applicable international human rights law. Physical and psychological abuse must crease and investigations into abusive treatment must be executed promptly and thoroughly., 181

Barack Obama assumiu o compromisso de fechar a prisão de Guantánamo, já no primeiro ano do seu governo. Em 22 de janeiro de 2009 , assinou uma resolução ${ }^{182}$ na qual, além do fechamento, foi decidido o tratamento a ser dado aos prisioneiros.

A descrição das práticas de confinamento, violência por parte dos guardas, ameaça de violência, abuso religioso, alimentação artificial forçada, dentre inúmeras outras agressões, demonstram que, mesmo após a entrada de Obama no governo, as condutas desumanas continuam.

A decisão de fechar a Prisão de Guantánamo não diminui a gravidade da existência da prática de tortura naquele local. Vale lembrar aqui o artigo $\mathrm{V}$ da Declaração Universal dos Direitos Humanos que determina que: "Ninguém será submetido à tortura, nem a tratamento ou castigo cruel, desumano ou degradante".

Em tese, não é permitida a tortura em Guantánamo. Em tese, os Estados Unidos não torturam. Bush já chegou a afirmar que "os Estados Unidos estão comprometidos com a eliminação mundial da tortura e lideram essa luta com o exemplo." ${ }^{183}$ Mas uma coisa é a teoria, outra, bem diferente, é a prática. Não é preciso muito esforço para se chegar à conclusão de que Guantánamo representa uma total abolição de todos os

\footnotetext{
${ }^{181}$ CENTER for Constitutional Rights. Op. cit.

182 THE WHITE HOUSE. Executive Order: Review and Dispositions of Individuals Detained at the Guantánamo Bay Naval Base and closure of Detention Facilities. 22 jan. 2009. Disponível em http://www.whitwhouse.gov/the_press_office/closureofGuantánamodetentionfacilities/. Acesso em 15 mai. 2009.

${ }^{183}$ George W. Bush em junho de 2003. GÓMEZ, José María. Op. cit. p. 267.
} 
diplomas de direitos humanos e de Direito humanitário já elaborados até hoje. Trata-se, na verdade, de uma violação de todos os direitos, vez que os presos são privados de todas as suas garantias, não sendo mais tratados como seres humanos, mas como objetos; passando a ser vistos, portanto, como descartáveis e sem valor. 


\section{CONCLUSÃO}

O ser humano é naturalmente suscetível ao medo. Tal sentimento, se manipulado de forma "adequada", torna-se uma fonte inesgotável e autorenovável de insegurança, fragilidade e subserviência.

Vivemos em uma sociedade do medo, em que estamos todos sempre temendo que algo de ruim afete nosso corpo, bens, posição social ou o funcionamento do mundo à nossa volta. Acreditamos estar constantemente rodeados de perigos prontos a nos atacar, que o podem fazê-lo a qualquer momento, bastando um simples momento de descuido de nossa parte.

Por isso, somos ensinados a estar sempre alertas e vigilantes. Somos levados a crer que o mundo em que habitamos é perigosíssimo e que novas ameaças surgem a cada dia e podem vir de todos os lados, principalmente dos outros seres humanos. Assim, internalizamos a noção de que o "outro" representa uma ameaça e está continuamente tentando nos passar para trás. Por esta razão, devemos desconfiar sempre e zelar pelo nosso próprio bemestar, segurança e felicidade, porque se não o fizermos, ninguém o fará, porque cada um cuida apenas de si mesmo. São estas as "verdades" a que somos expostos desde a infância e que nos acompanham por toda a vida.

Desta maneira, a vida se torna uma guerra interminável, movida pela máquina do medo. Esta situação é perpetuada pela mídia e outros formadores de opinião, todos trabalhando em conjunto para manter a ordem das coisas. Só a partir do medo, bem como de outros meios de controle social, é possível manter a população sob controle e servil, para assegurar o pleno funcionamento do sistema capitalista-liberal, sempre beneficiando uma minoria privilegiada, em detrimento de uma maioria de excluídos.

A presente pesquisa permitiu compreender melhor esses mecanismos de dominação, assim como o fenômeno do terrorismo e a atual "guerra 
contra o terror". Foi possível perceber que, de fato, tal guerra serve de pretexto para dar continuidade à política externa dos Estados Unidos, que faz uso cada vez mais recorrente da "violência imperial" "184, com o objetivo último de manter a hegemonia norte-americana - intervindo em nações que contrariem e ofereçam risco à ordem mundial e punindo os indivíduos que se recusem a ser complacentes com tal realidade.

É neste contexto que entra a figura do terrorista, que passa a ser encarado como "inimigo da humanidade" "185, ainda que, paradoxalmente, os próprios governos dos Estados, por vezes, pratiquem atos mais horrendos e com mais vítimas do que as atividades "terroristas". Contudo, "uma mágica faz com que ninguém perceba as suas próprias práticas de terror"186. Os atos praticados pelos Estados dominantes nunca são vistos como atos de terror, mas como "intervenções humanitárias" ou "legítima defesa".

O "inimigo da humanidade" deve ser perseguido e eliminado, por, supostamente, colocar em xeque a segurança mundial. Tal afirmativa serve de legitimação para a prática da mais ampla gama de ações, como a supressão de liberdades individuais, a invasão militar e o cometimento das atrocidades vistas em Guantánamo.

É evidente a completa a violação dos direitos humanos dos prisioneiros de Guantánamo. Para começar, estes indivíduos, que ainda estão detidos ou por lá já passaram, foram apreendidos sem acusação, sob o argumento de se tratar de "suspeitos" de envolvimento com terrorismo. Sem inquérito, sem julgamento e sem acesso à maioria das suas garantias fundamentais. As condiçõos de encarceramento e a tortura a que são submetidos são um caso à parte e representam, da mesma forma, um golpe

\footnotetext{
${ }^{184}$ GÓMEZ, José María. Op. cit. p. 293.

${ }^{185}$ Ibid. p. 282.

${ }^{186}$ DORNELLES, João Ricardo W. Guerra Imperial Permanente versus Direitos Humanos. p. 15.
} 
brutal no Direito internacional dos direitos humanos e no Direito humanitário.

Difícil é compreender como isto se tornou realidade em um mundo formado, em sua maior parte, por países que se dizem democráticos. Pôdese constatar, ainda, que as estratégias ofensivas de segurança, nacionais e internacionais, não têm o objetivo de acabar com a insegurança e com o medo; muito pelo contrário, visam propagá-los e fortalecê-los. Pois o medo

“cumpre papel imobilizador e neutraliza os descontentamentos e a crítica. O medo legitima as ações arbitrárias, tanto no mundo, quanto dentro das fronteiras nacionais, com as perseguições aos trabalhadores estrangeiros, a censura, as ações violentas contra as comunidades islâmica, árabe e latinoamericana. O medo cria a desconfiança em relação ao "Outro", ao estranho, ao estrangeiro, ao diferente."

Apenas por meio da proliferação do medo é que se torna possível implantar o modelo Guantánamo e permitir a prática de tortura e maustratos aos prisioneiros. A partir do temor é que se põe em prática as medidas que garantem a continuidade do poder hegemônico e da ordem neoliberal global.

${ }^{187}$ Ibid. p. 9. 


\section{BIBLIOGRAFIA}

\section{Livros}

AGAMBEN,Giorgio. Estado de Exceção - Homo Sacer, II, 1. 2a Ed. São Paulo: Boitempo, 2007. 142 p.

. Homo Sacer - O Poder Soberano e a Vida Nua I. Belo

Horizonte: Editora UFMG, 2002. 207 p.

BAUMAN, Zigmunt. Globalização: As consequências humanas. Rio de Janeiro: Jorge Zahar Editor, 1999. 146 p.

. Medo Líquido. Rio de Janeiro: Jorge Zahar Ed., 2008.

239 p.

CHOMSKY, Noam. Democracia e mercados na nova ordem mundial. In: GENTILI, Pablo (org.). Globalização excludente: desigualdade, exclusão e democracia na nova ordem mundial. Petrópolis: Vozes; Buenos Aires: CLACSO, 2000. p. 7-45.

CHOMSKY, Noam. 11 de setembro. Rio de Janeiro: Bertrand Brasil, 2005. $160 \mathrm{p}$.

Império americano: hegemonia ou sobrevivência. Rio

de Janeiro: Elsevier, 2004. 273 p.

COMISIÓN INTERAMERICANA DE DERECHOS HUMANOS. Informe Sobre Terrorismo y Derechos Humanos. Washington: OEA, 2002. 296p.

DORNELLES, João Ricardo W.. Conflito e Segurança: Entre pombos e falcões. Rio de Janeiro: Editora Lumen, 2008. 222p.

. O Sistema penal construindo a figura do inimigo: a criminalização dos pobres como estratégia hegemônica neoliberal. In: BITTAR, Eduardo C.B.; TOSI, Giuseppe. (Org.). Democracia e Educação em Direitos Humanos numa época de insegurança. Brasília: Secretaria Especial dos Direitos Humanos da Presidência da República, 2008. p. 335338.

FLETCHER, Laurel. STOVER, Eric. Guantánamo and its aftermath: U.S detention and interrogation practices and their impact on former detainees. 
Berkeley: Human Rights Center, University of California Berkeley, 2008. $124 p$.

KAYSEN, Carl; MILLER, Steven E.; MALIN, Martin B.; NORDHAUS, Willian D.; STEINBRUNER. War with Iraq: Cost, Consequences, and alternatives. Cambridge: American Academy of Arts and Sciences, 2002. $88 \mathrm{p}$.

MALUGUTI BATISTA, Vera. O medo na cidade do Rio de Janeiro: dois tempos de uma história. Rio de Janeiro: Revan, 2003. 272p.

OLIVEIRA, Filipe. Refugiados e Direitos Humanos nas Prisões. In: HUMANA GLOBAL. A Organização das Nações Unidas. Coimbra: Associação para a Promoção dos Direitos Humanos, da Cultura e do Desenvolvimento, 2007. p. 243-292

\section{Dissertações e teses}

RABELO, Aline Louro de Souza e Silva. O conceito do terrorismo nos jornais americanos: uma análise do New York Times e do Washington Post logo após os atentados de 11 de setembro. Rio de Janeiro. 2007. 171p. Dissertação (Mestrado em Relações Internacionais) - Departamento de Relações Internacionais, PUC-RIO.

\section{Revistas e artigos}

AMNESTY International. Amnesty International Report 2009: State of the World's Human Rights. 30 mai. 2009. Disponível (em português) em <http://report2009.amnesty.org/press-area/pt-br/download-report>. Acesso em 31 mai. 2009.

. Off the Record: U.S. Responsibility for Enforced Disappearances in the "War on Terror". London: Amnesty Internacional, $2007 . \quad$ Disponível em <http://www.amnesty.org/en/library/info/AMR51/093/2007>. Acesso em 19 mai. 2009.

BUTKO, Thomas. Terrorism redefined: terrorism as "counter-hegemonic political violence". In: 2005 CPSA Annual Conference. Ottawa: Canadian Political Science Association, 2005. Disponível em <http://www.cpsa- 
acsp.ca/template_e.cfm?folder =conference\&page_name=agm-papers2005.htm>. Acesso em 19 mai. 2009.

CENTER for Constitutional Rights. Current conditions of confinement at Guantánamo. New York: CCRjustice, 2009. Disponível em $<$ http://ccrjustice.org/learn-more/reports/current-conditions-confinementguantanamo>. Acesso em 20 mai. 2009.

DENBEAUX, Mark. Report on Guantánamo Detainees A Profile of 517 Detainees through Analysis of Department of Defense Data. Guantánamo Reports, Seton Hall University School of Law, 8 fev.2006. Disponível em $<$ http://law.shu.edu/ProgramsCenters/PublicIntGovServ/CSJ/GuantanamoReports.cfm>. Acesso em 28 abr. 2009.

DEEN, Thalif. Nações Unidas: Em busca de uma definição para terrorismo. IPS-Inter Press Service, 27 mai. 2005. Disponível em <http://www. mwglobal.org/ipsbrasil.net/nota.php?idnews=831>. Acesso em 20 mai. 2009.

DEPARTAMENTO DE ESTADO dos Estados Unidos. Padrões de Terrorismo Global - 2000. Embaixada Americana no Brasil. 2001. Disponível em <http://terrorismo.embaixada-americana.org.br/ 2000 intro.htm>. Acesso em 25 abr. 2009.

DORNELLES, João Ricardo W. Guerra Imperial Permanente versus Direitos Humanos. Artigo apresentado no Seminário "Direitos Humanos Viena + 10 - Desafios e Perspectivas". Núcleo de Direitos Humanos da PUC-Rio, out. 2003.

FUKUYAMA, Francis. The End of History? The National Interest, 1989. Disponível em <www.unc.edu/ rlstev/Text/Fukuyama\%20End\%20of\%20History.pdf>. Acesso em 24 mai. 2009.

GÓMEZ, José María. Soberania imperial, espaços de exceção e o campo de Guantánamo: desterritorialização e confinamento na "guerra contra o terror". Contexto Internacional: Revista do Instituto de Relações Internacionais (IRI) da Pontifícia Universidade Católica do Rio de Janeiro PUC-Rio. Rio de Janeiro, vol. 30, no. 2, p. 267-308, ago. 2008. Disponível em<http://publique.rdc.pucrio.br/contextointernacional/cgi/cgilua.exe/sys/st art.htm?infoid=473\&sid=67>. Acesso em 10 mai. 2009.

INTERNATIONAL COURT OF JUSTICE. Military and Paramilitary Activities in and against Nicaragua (Nicaragua v. United States of 
America). Disponível em <http://www.icjcij.org/docket/index.php?p1 $=3 \& \mathrm{p} 2=3 \& \mathrm{k}=66 \&$ case $=70 \&$ code $=$ nus $\& \mathrm{p} 3=4>$. Acesso em 29 mai. 2009.

IRAQ BODY COUNT. The Weapons that kill civilians - Deaths of children and noncombatants in Iraq, 2003 - 2008. Disponível em http://www.iraqbodycount.org/. Acesso em 30 mai. 2009.

KAKAR, Kawun. An Introduction of the Taliban. Institute for Afghan Studies, outono 2002. Disponível em <http://www.institute-for-afghanstudies.org/AFGHAN\%20CONFLICT/TALIBAN/intro_kakar.htm>.

Acesso em 15 abr. 2009.

LAWRENCE, Carmen. Fear of Annihilation. Disponível em <http://www.albany.uwa.edu.au/pdf/Lawrence\%20Fear\%20of\%20Annihila tion.pdf $>$. Acesso em 21 mai. 2009.

MELLO, Patricia Campo; SIMON, Roberto. Saiba mais sobre a base naval americana de Guantánamo: Prisão para suspeitos de terrorismo provoca polêmica entre ativistas de direitos humanos e países estrangeiros. $\mathrm{O}$ Estado de S. Paulo, São Paulo, 22 jan. 2009. Disponível em <http://www.estadao.com.br/internacional/not_int311148,0.htm>. Acesso em 28 mai.2009.

MURPHY, M.E.. The History of Guantanamo Bay 1494-1964. Rear Admiral, U.S. Navy, U.S. Naval Base Guantanamo Bay, 5 Jan. 1953. Disponível em < http://www.cnic.navy.mil/guantanamo/index.htm>. Acesso em 30 mai. 2009.

NAVAL STATION Guantanamo Bay. History of U.S. Naval Station Guantanamo Bay. Guantanamo Bay Gazette, Vol. 66, No. 13, Guantanamo, Disponível em < http://www.cnic.navy.mil/guantanamo/index.htm>. Acesso em 30 mai. 2009.

PARLAMENTO EUROPEU. Poderá a Europa acolher os prisioneiros de Guantanamo? 03 mar. 2009. Disponível em <http://europarl.europa.eu/side/getDoc.do?pubRef=-//EP//TEXT+IM->. Acesso em 25 mai. 2009.

POMFRET, John. The History of Guantanamo Bay 1964 - 1982. U.S. Naval Base Guantanamo Bay, Cuba. Disponível em < http://www.cnic.navy.mil/guantanamo/index.htm>. Acesso 30 mai. 2009. 
ROTH, Ken. War in Iraq: Not a Humanitarian Intervention. In: World Report 2004: Human Rights and Armed Conflict. New York: Human Rights Watch, 2004. Disponível em <http://www.hrw.org/legacy/wr2k4/>. Acesso em 20 mai. 2009.

THE NEW YORK TIMES. The Guantánamo Docket. Disponível em <http://projects.nytimes.com/guantanamo>. Acesso em 01 jun. 2009.

THE WHITE HOUSE. Executive Order: Review and Dispositions of Individuals Detained at the Guantanamo Bay Naval Base and closure of Detention Facilities. 22.jan.2009. Disponível em http://www.whitwhouse.gov/the_press_office/closureofguantanamodetentio nfacilities/. Acesso em 15 mai. 2009.

UNITED STATES Department of the Treasury. Office of Foreign Assets Control. Terrorist Assets Report. Calendar Year 2007 Sixteenth Annual Report to Congress on Assets in the United States of Terrorist Countries and International Terrorism Program Designees Office. Disponível em <http://www.ustreas.gov/offices/enforcement/ofac/reports/tar2007.pdf>. Acesso em 31 mai. 2009.

. Department of the Treasury. Office of Foreign Assets Control. Terrorism List Governments Sanctions Regulations. 18 mai. 2009. Disponível em <http://www.treas.gov/offices/enforcement/ofac/legal/regs/fr74_23111.pdf $>$. Acesso em 31 mai. 2009.

WALLERSTEIN, Immanuel. Afeganistão: bancos de areia na rota do presidente Obama. Fernand Braudel Center, Binghamton University, 01 jun. 2008. Disponível em <http://fbc.binghamton.edu/commentr.htm>. Acesso em 28 mai.2009.

Af-Pak: Obama's War. Fernand Braudel Center, Binghamton University, 01 abr.2009. Disponível em <http://www.binghamton.edu/fbc/254en.htm> . Acesso em 28 mai.2009.

. Como a Guerra do Iraque vai acabar. Fernand Braudel

Center, Binghamton University, 01 jun. 2008. Disponível em <http://fbc.binghamton.edu/commentr.htm>. Acesso em 28 mai.2009.

WINGFIELD-HAYES, Rupert. Análise: Questão da Chechênia está longe da resolução. BBC Brazil, Moscou, 16 abr. 2009. Disponível em <http://www.bbc.co.uk/portuguese/noticias/2009/04/090416_analisecheche niamv.shtml>. Acesso em 19 mai. 2009. 


\section{Notícias}

ANISTIA Internacional. EUA: Preocupação Jurídica - 17 detidos uigur reclusos em Guantanamo. Anistia Internacional, 7 mai. 2009. Disponível em <http://www.br.amnesty.org/?q=note/304>. Acesso em 23 mai. 2009

AFP Agence France-Presse. Até o diabo não poderia acreditar em Guantanamo. AFP, 05 mai. 2009. Disponível em $<$ http://ultimosegundo.ig.com.br/mundo/2009/05/05/ate+o+diabo+nao+pod eria+acreditar+em+guantanamo+5952912.html> . Acesso em 22 maio.2009.

Em cinco anos Guantánamo arruinou centenas de vidas

e a reputação dos EUA. AFP, 10 jan. 2007. Disponível em <http://g1.globo.com/Noticias/Mundo/0,,AA1415272-5602,00.html>.

Acesso em 28 abr. 2009.

- Tribunal de Guantánamo condena motorista de Bin Laden a 5,5 anos. G1 Globo, 07 ago. 2008. Disponível em <http://g1.globo.com/Noticias/Mundo/0,,MUL715688-5602,00-

TRIBUNAL+DE+GUANTANAMO+CONDENA+MOTORISTA+DE+BI N+LADEN+A+ANOS.html> . Acesso em 15 abr.2009

- Guantánamo, símbolo dos excessos da "luta contra o

terrorismo" de Bush. AFP, 21 jan. 2009. Disponível em $<$ http://www.abril.com.br/noticias/mundo/guantanamo-simbolo-excessosluta-terrorismo-bush-243529.shtml>. Acesso em 20 abr.2009.

ASSOCIATED PRESS. Número mensal de mortos no Iraque atinge menor índice desde início da guerra. Folha Online, 24 abr. 2009. Disponível em <http://www1.folha.uol.com.br/folha/mundo/ult94u555662.shtml> Acesso em 30 mai. 2009.

BBC BRASIL. Guantánamo: Único condenado por terrorismo é solto. $O$ Estadão, 29 dez. 2007. Disponível em <http://www.estadao.com.br/noticias/geral,guantanamo-unico-condenadopor-terrorismo-e-solto,102319,0.htm>. Acesso em 15 abr.2009.

Saiba mais sobre os tribunais militares em Guantanamo.

G1 GLOBO, 06 ago. 2008. Disponível em <http://g1.globo.com/Noticias/Mundo/0,,MUL7145685602,00SAIBA+MAI S+SOBRE+OS+TRIBUNAIS+MILITARES+EM+GUANTANAMO.html >. Acessado em 22 mai. 200 
Tribunal dos EUA nega libertação de presos de

Guantánamo. BBC, 18 fev. 2009. Disponível em <http://www.bbc.co.uk/portuguese/noticias/2009/02/090218_guantanamo_ prisaorg.shtml>. Acesso em 02 mai.2009.

_. Obama pede suspensão de julgamentos em Guantánamo. BBC Brasil, 21 jan. 2009. Disponível em $<$ http://www1.folha.uol.com.br/folha/bbc/ult272u492559.shtml. Acesso em 15 mai. 2009.

BUARQUE, Daniel. Iraque completa seis anos em guerra sem previsão de independência real. G1 GLOBO, 20 mar. 2009. Disponível em <http://g1.globo.com/Noticias/Mundo/0,,MUL1050628-5602,00IRAQUE+COMPLETA+SEIS+ANOS+EM+GUERRA+SEM+PREVISAO +DE+INDEPENDENCIA+REAL.html> . Acesso em 24 mai.2009.

EREDIA, Talita. Al-Qaeda se transforma em "franquia" ideológica. $O$ Estadão, $\quad 01 \quad$ set. $2008 . \quad$ Disponível em <http://www.estadao.com.br/noticias/internacional,al-qaeda-se-transformaem-franquia-ideologica,239818,0.htm>. Acesso em 28 de abr. 2009.

FOLHA ON LINE. Cronologia do conflito no Iraque. Folha On Line. Disponível em <http://www1.folha.uol.com.br/folha/mundo/ult94u383081.shtml>. Acesso em 15 mai. 2009.

KADIEV, Aslambeck. A guerra da Rússia, na ótica da Chechênia. $B B C$ Brazil, Grosny, 28 dez. 1999. Disponível em <http://www.bbc.co.uk/portuguese/omundohoje/omh99122805.htm>. Acesso em 19 mai. 2009.

MARTIN, David. Bush Takes On 'Axis Of Evil': U.S. Restores Funding To Iraqi Opposition Group. CBS News, 30 jan. 2002. Disponível em <http://www.cbsnews.com/stories/2002/01/30/terror/main326225.shtml. Acesso em 10 abr.2009>. Acesso em 30 abr. 2009.

O ESTADÃO. A pedido de Obama, Justiça congela $1^{\circ}$ processo de Guantánamo. O Estadão Internacional, 21 jan. 2009. Disponível em <http://www.estadao.com.br/noticias/internacional,a-pedido-de-obamajustica-congela-1-processo-de-guantanamo,310640,0.htm>. Acesso em 15 abr. 2009

SANDBERG, Britta. EUA preparam primeiros julgamentos dos detidos em Guantánamo. Der Spigel, 25 mar. 2007. Disponível em 
<http://noticias.uol.com.br/midiaglobal/derspiegel/2007/03/25/ult2682u403. jhtm>. Acesso em 14 abr. 2009.

SAVAGE, Charlie. Freed from Guantanamo, 5 face danger in Albania. The Boston Globe, 18 mai. 2006. Disponível em <http://www.boston.com/news/nation/washington/articles/2006/05/18/freed _from_guantanamo_5_face_danger_in_albania/>. Acesso em 30 abr. 2009. 


\section{ANEXO I - TABELAS}

\section{A Tabela 01 [Prisioneiros transferidos da Prisão de Guantánamo}

(Cuba) para outros países (até 01 de Junho de 2009)], a Tabela 02 [Prisioneiros remanescentes na Prisão de Guantánamo (Cuba) (até 01 de Junho de 2009)] e a Tabela 03 [Prisioneiros mortos na Prisão de Guantánamo (2002 até 01 de junho de 2009)], foram elaboradas com os dados da base de dados interativa (online) The Guantánamo Docket, produzida pelo The New York Times, com informações do Banco de Dados do Pentágono, do Departamento de Defesa dos Estados Unidos e outros. O período da pesquisa abrange de janeiro de 2002 até maio de 2009. A base de dados The Guantánamo Docket está disponível no website: http://projects.nytimes.com/Guantánamo.

Segundo os números do The Guantánamo Docket ${ }^{188}$, foram registradas (detidas) 779 pessoas na Prisão de Guantánamo, destas 544 foram transferidas, 6 morreram (suicídio) e 229 ainda se encontram na prisão.

\section{Tabela 01}

\begin{tabular}{|c|c|c|c|c|}
\hline \multicolumn{5}{|c|}{$\begin{array}{l}\text { Prisioneiros transferidos da Prisão de Guantánamo (Cuba) para outros países. } \\
\text { (Até } 01 \text { de Junho de 2009) }\end{array}$} \\
\hline $\mathbf{N}^{\mathbf{o}}$ & Nome & Naciolidade & $\begin{array}{c}\text { Data da } \\
\text { Transfer. }\end{array}$ & Transferido para \\
\hline 1 & Abahanov, Yakub & Cazaquistão & 15-dez-06 & Cazaquistão \\
\hline 2 & Abasin, Said & Afeganistão & 23-mar-03 & Afeganistão \\
\hline 3 & Abulwance, Yamatolah & Afeganistão & 14-mar-04 & Afeganistão \\
\hline 4 & Achezkai, Haji Mohammed Khan & Afeganistão & 14-mar-04 & Afeganistão \\
\hline 5 & Adam Gul, Ataullah & Afeganistão & 14-mar-04 & Afeganistão \\
\hline 6 & Ahmad, Abdul & Afeganistão & 28 -set-07 & Afeganistão \\
\hline 7 & Ahmad, Noor & Afeganistão & 16-jul-03 & Afeganistão \\
\hline 8 & Ahmed, Feda & Afeganistão & $18-a b r-05$ & Afeganistão \\
\hline 9 & Ahmed, Shabir & Afeganistão & 2-nov-07 & Afeganistão \\
\hline 10 & Akhbar, Mohammad & Afeganistão & 16-jul-03 & Afeganistão \\
\hline 11 & Akhtar Mohammed, Rostum & Afeganistão & 9-mai-03 & Afeganistão \\
\hline
\end{tabular}

188 THE NEW YORK TIMES. The Guantánamo Docket. Disponível em <http://projects.nytimes.com/Guantánamo>. Acesso em 01 jun.2009. 


\begin{tabular}{|c|c|c|c|c|}
\hline \multicolumn{5}{|c|}{$\begin{array}{l}\text { Prisioneiros transferidos da Prisão de Guantánamo (Cuba) para outros países. } \\
\text { (Até 01 de Junho de 2009) }\end{array}$} \\
\hline $\mathbf{N}^{\mathbf{o}}$ & Nome & Naciolidade & $\begin{array}{l}\text { Data da } \\
\text { Transfer. }\end{array}$ & Transferido para \\
\hline 12 & al Kunduzi, Umar Abdullah & Afeganistão & 12-dez-07 & Afeganistão \\
\hline 13 & Alikhan, Mahngur & Afeganistão & 9-mai-03 & Afeganistão \\
\hline 14 & Alikozi, Amanullah & Afeganistão & 14-mar-04 & Afeganistão \\
\hline 15 & Aliza, Abdul Rauf & Afeganistão & 12-dez-07 & Afeganistão \\
\hline 16 & Alizai, Nematullah Sahib Khan & Afeganistão & 9-mai-03 & Afeganistão \\
\hline 17 & Allah, Noor & Afeganistão & 18 -set-04 & Afeganistão \\
\hline 18 & Aman & Afeganistão & 11-out-06 & Afeganistão \\
\hline 19 & Amanullah & Afeganistão & 18-set-04 & Afeganistão \\
\hline 20 & Andarr, Abdul al Hameed Mohammed & Afeganistão & 14-mar-04 & Afeganistão \\
\hline 21 & Asekzai, Azizullah & Afeganistão & 16-jul-03 & Afeganistão \\
\hline 22 & Aslaam, Noor & Afeganistão & 14-mar-04 & Afeganistão \\
\hline 23 & Azimullah & Afeganistão & 24-abr-07 & Afeganistão \\
\hline 24 & Badr, Badruzzan & Afeganistão & 18 -set-04 & Afeganistão \\
\hline 25 & Bagi, Abdul & Afeganistão & 8-fev-06 & Afeganistão \\
\hline 26 & Baqi, Abdul & Afeganistão & 18-nov-03 & Afeganistão \\
\hline 27 & Barak & Afeganistão & 14-mar-04 & Afeganistão \\
\hline 28 & Barakzai, Jon Mohammad & Afeganistão & 28 -out- 02 & Afeganistão \\
\hline 29 & Baridad & Afeganistão & 15-dez-06 & Afeganistão \\
\hline 30 & Bismaullah & Afeganistão & 18 -set-04 & Afeganistão \\
\hline 31 & Bismillah & Afeganistão & 14-mar-04 & Afeganistão \\
\hline 32 & Bismillah & Afeganistão & 23-mar-03 & Afeganistão \\
\hline 33 & Bismullah, Haji & Afeganistão & 17-jan-09 & Afeganistão \\
\hline 34 & Bullar, Mohi & Afeganistão & 28 -set-07 & Afeganistão \\
\hline 35 & Chaman, Gul & Afeganistão & 12-dez-07 & Afeganistão \\
\hline 36 & Dad, Khudai & Afeganistão & 8-fev-06 & Afeganistão \\
\hline 37 & Daoud, Mohamman & Afeganistão & 18 -set-04 & Afeganistão \\
\hline 38 & Din, Juma & Afeganistão & 28 -set-07 & Afeganistão \\
\hline 39 & Edmondada, Abdullah & Afeganistão & 23-mar-03 & Afeganistão \\
\hline 40 & Ehsanullah & Afeganistão & 23-mar-03 & Afeganistão \\
\hline 41 & Ehssanullah & Afeganistão & 9-mai-03 & Afeganistão \\
\hline 42 & Esmatulla & Afeganistão & 30 -abr-08 & Afeganistão \\
\hline 43 & Esmhatulla, Qari & Afeganistão & 11-out-06 & Afeganistão \\
\hline 44 & Far Huddine, Bar & Afeganistão & 14-mar-04 & Afeganistão \\
\hline 45 & Farhad, Din Mohammed & Afeganistão & 18 -set-04 & Afeganistão \\
\hline 46 & Farouq, Mohammed Nayim & Afeganistão & 16-jul-03 & Afeganistão \\
\hline 47 & Ghafaar, Abdul & Afeganistão & 12-dez-07 & Afeganistão \\
\hline 48 & Ghafoor, Shai Jahn & Afeganistão & 23-mar-03 & Afeganistão \\
\hline 49 & Ghafour, Abdul & Afeganistão & 12-dez-07 & Afeganistão \\
\hline 50 & Ghalib, Haji & Afeganistão & 28-fev-07 & Afeganistão \\
\hline 51 & Ghani, Abdul & Afeganistão & 7-ago-07 & Afeganistão \\
\hline 52 & Ghani, Nabu Abdul & Afeganistão & 18-nov-03 & Afeganistão \\
\hline 53 & Ghofoor, Abdullah & Afeganistão & 14-mar-04 & Afeganistão \\
\hline 54 & Ghul, Nathi & Afeganistão & 16-jul-03 & Afeganistão \\
\hline 55 & Ghul, Wazir Zalim & Afeganistão & 18-nov-03 & Afeganistão \\
\hline 56 & Ghuladkhan & Afeganistão & 16-jul-03 & Afeganistão \\
\hline 57 & Gul Ghaman, Nasser & Afeganistão & $28-\mathrm{fev}-07$ & Afeganistão \\
\hline 58 & Gul, Dawd & Afeganistão & 18 -set-04 & Afeganistão \\
\hline 59 & Gul, Mohammad & Afeganistão & 18 -abr-05 & Afeganistão \\
\hline 60 & Hafizullah & Afeganistão & 15-dez-06 & Afeganistão \\
\hline 61 & Hamdullah & Afeganistão & 14-mar-04 & Afeganistão \\
\hline 62 & Hamidullah & Afeganistão & 18-nov-03 & Afeganistão \\
\hline 63 & Hammdidullah & Afeganistão & 18 -abr-05 & Afeganistão \\
\hline 64 & Hanan, Abdul & Afeganistão & 9-mai-03 & Afeganistão \\
\hline
\end{tabular}




\begin{tabular}{|c|c|c|c|c|}
\hline \multicolumn{5}{|c|}{$\begin{array}{l}\text { Prisioneiros transferidos da Prisão de Guantánamo (Cuba) para outros países. } \\
\text { (Até 01 de Junho de 2009) }\end{array}$} \\
\hline $\mathbf{N}^{\mathbf{o}}$ & Nome & Naciolidade & $\begin{array}{c}\text { Data da } \\
\text { Transfer. }\end{array}$ & Transferido para \\
\hline 65 & Hasan, Mirwais & Afeganistão & 14-mar-04 & Afeganistão \\
\hline 66 & Hekmat, Abdullah & Afeganistão & 2-nov-07 & Afeganistão \\
\hline 67 & Hezbullah & Afeganistão & 18-nov-03 & Afeganistão \\
\hline 68 & Hukumra & Afeganistão & 18 -abr-05 & Afeganistão \\
\hline 69 & Insanullah & Afeganistão & 18-nov-03 & Afeganistão \\
\hline 70 & Ismail, Mohammed & Afeganistão & 28-jan-04 & Afeganistão \\
\hline 71 & Jalil, Haji & Afeganistão & 11-mar-05 & Afeganistão \\
\hline 72 & Jan, Said Amir & Afeganistão & 28 -set-07 & Afeganistão \\
\hline 73 & Jan, Saida & Afeganistão & 11-out-06 & Afeganistão \\
\hline 74 & Kabel, Mohamed & Afeganistão & 23-mar-03 & Afeganistão \\
\hline 75 & Kadir, Khandan & Afeganistão & 11-out-06 & Afeganistão \\
\hline 76 & $\begin{array}{l}\text { Kahm, Abdul Rahman Abdullah } \\
\text { Mohamed Juma }\end{array}$ & Afeganistão & 15-dez-06 & Afeganistão \\
\hline 77 & Kakar, Mohammed Raz Mohammed & Afeganistão & 9-mai-03 & Afeganistão \\
\hline 78 & Kandahari, Kako & Afeganistão & 18 -abr-05 & Afeganistão \\
\hline 79 & Karim, Abdul & Afeganistão & 9-mai-03 & Afeganistão \\
\hline 80 & Khail, Hafizullah Shabaz & Afeganistão & 12-dez-07 & Afeganistão \\
\hline 81 & Khan, Abdullah & Afeganistão & 8-fev-06 & Afeganistão \\
\hline 82 & Khan, Abdullah Mohammad & Afeganistão & $30-a b r-08$ & Afeganistão \\
\hline 83 & Khan, Alif & Afeganistão & 23-mar-03 & Afeganistão \\
\hline 84 & Khan, Anwar & Afeganistão & 11-out-06 & Afeganistão \\
\hline 85 & Khan, Ezat & Afeganistão & 23-mar-03 & Afeganistão \\
\hline 86 & Khan, Haji Nasrat & Afeganistão & 25 -ago-06 & Afeganistão \\
\hline 87 & Khan, Hazrat Sangin & Afeganistão & 14-mar-04 & Afeganistão \\
\hline 88 & Khan, Janan Taus & Afeganistão & 18-nov-03 & Afeganistão \\
\hline 89 & Khan, Juma & Afeganistão & 18-nov-03 & Afeganistão \\
\hline 90 & Khan, Kakai & Afeganistão & 11-out-06 & Afeganistão \\
\hline 91 & Khan, Mohabet & Afeganistão & 11-out-06 & Afeganistão \\
\hline 92 & Khan, Mohammed & Afeganistão & 18 -set-04 & Afeganistão \\
\hline 93 & Khan, Osman & Afeganistão & 14-mar-04 & Afeganistão \\
\hline 94 & Khan, Shardar & Afeganistão & 11-out-06 & Afeganistão \\
\hline 95 & Khan, Swar & Afeganistão & 11-out-06 & Afeganistão \\
\hline 96 & Khirullah Akah & Afeganistão & 18-nov-03 & Afeganistão \\
\hline 97 & Kuchi, Haji Niam & Afeganistão & 18 -set-04 & Afeganistão \\
\hline 98 & Layar, Sabit & Afeganistão & 16-jul-03 & Afeganistão \\
\hline 99 & Malang, Nassir & Afeganistão & 23-mar-03 & Afeganistão \\
\hline 100 & Matin, Abdul & Afeganistão & 12-dez-07 & Afeganistão \\
\hline 101 & Mehsud, Abdullah & Afeganistão & 14-mar-04 & Afeganistão \\
\hline 102 & Melma, Sabar Lal & Afeganistão & 28 -set-07 & Afeganistão \\
\hline 103 & Mirmuhammad, Sharghulab & Afeganistão & 23-mar-03 & Afeganistão \\
\hline 104 & Mohammad, Akhtar & Afeganistão & 14-mar-04 & Afeganistão \\
\hline 105 & Mohammad, Akhtiar & Afeganistão & 15-dez-06 & Afeganistão \\
\hline 106 & Mohammadullah & Afeganistão & 16-jul-03 & Afeganistão \\
\hline 107 & Mohammed, Akhtar & Afeganistão & 25-ago-06 & Afeganistão \\
\hline 108 & Mohammed, Alif & Afeganistão & 15-dez-06 & Afeganistão \\
\hline 109 & Mohammed, Haji Faiz & Afeganistão & 28 -out-02 & Afeganistão \\
\hline 110 & Mohammed, Mirza & Afeganistão & 23-mar-03 & Afeganistão \\
\hline 111 & $\begin{array}{l}\text { Mohammed, Rasool Shahwali Zair } \\
\text { Mohammed }\end{array}$ & Afeganistão & 18 -abr-05 & Afeganistão \\
\hline 112 & Mohammed, Said & Afeganistão & 25 -ago-06 & Afeganistão \\
\hline 113 & Mohammed, Sultan & Afeganistão & 9-mai-03 & Afeganistão \\
\hline 114 & Mohammed, Taj & Afeganistão & 11-out-06 & Afeganistão \\
\hline 115 & Mohammed, Wali & Afeganistão & 18 -set-04 & Afeganistão \\
\hline
\end{tabular}




\begin{tabular}{|c|c|c|c|c|}
\hline \multicolumn{5}{|c|}{$\begin{array}{l}\text { Prisioneiros transferidos da Prisão de Guantánamo (Cuba) para outros países. } \\
\text { (Até 01 de Junho de 2009) }\end{array}$} \\
\hline $\mathbf{N}^{\mathbf{o}}$ & Nome & Naciolidade & $\begin{array}{c}\text { Data da } \\
\text { Transfer. }\end{array}$ & Transferido para \\
\hline 116 & Mousavi, Ali Shah & Afeganistão & 11-out-06 & Afeganistão \\
\hline 117 & Muhammed, Peta & Afeganistão & 14-mar-04 & Afeganistão \\
\hline 118 & Muhibullah & Afeganistão & $23-$ jul-05 & Afeganistão \\
\hline 119 & Mujahid, Abdullah & Afeganistão & 12-dez-07 & Afeganistão \\
\hline 120 & Muslim Dost, Abdul Rahim & Afeganistão & 18 -abr-05 & Afeganistão \\
\hline 121 & Must, Yarass Ali & Afeganistão & 23-mar-03 & Afeganistão \\
\hline 122 & Naserullah & Afeganistão & 2-nov-07 & Afeganistão \\
\hline 123 & Nasibullah & Afeganistão & 18 -abr-05 & Afeganistão \\
\hline 124 & Nasim, Mohammad & Afeganistão & 14-mar-04 & Afeganistão \\
\hline 125 & Nasim, Mohammed & Afeganistão & 11-out-06 & Afeganistão \\
\hline 126 & Nasim, Mohammed & Afeganistão & 18 -abr-05 & Afeganistão \\
\hline 127 & Nasir, Abdul & Afeganistão & 2-nov-07 & Afeganistão \\
\hline 128 & Nasir, Allah & Afeganistão & 28 -set-07 & Afeganistão \\
\hline 129 & Nasrat Yar, Hiztullah & Afeganistão & 2-nov-07 & Afeganistão \\
\hline 130 & Nasrullah & Afeganistão & 30 -abr-08 & Afeganistão \\
\hline 131 & Noor, Habib & Afeganistão & 18 -abr-05 & Afeganistão \\
\hline 132 & Noorallah, Haji & Afeganistão & 25-ago-06 & Afeganistão \\
\hline 133 & Noorani, Abdul Rahman & Afeganistão & 16-jul-03 & Afeganistão \\
\hline 134 & Peerzai, Qari Hasan Ulla & Afeganistão & 25-ago-06 & Afeganistão \\
\hline 135 & Quasam, Mohammed & Afeganistão & 2-nov-07 & Afeganistão \\
\hline 136 & Qudus, Abdul & Afeganistão & 18 -abr-05 & Afeganistão \\
\hline 137 & Rahim, Abdul & Afeganistão & 14-mar-04 & Afeganistão \\
\hline 138 & Rahmad, Nisar & Afeganistão & 16-jul-03 & Afeganistão \\
\hline 139 & Rahman, Abdul & Afeganistão & 18 -abr-05 & Afeganistão \\
\hline 140 & Rahman, Fizaulla & Afeganistão & 2-nov-07 & Afeganistão \\
\hline 141 & Rahman, Habib & Afeganistão & 11-out-06 & Afeganistão \\
\hline 142 & Rahman, Mahbub & Afeganistão & 31-ago-08 & Afeganistão \\
\hline 143 & Rahman, Murtazah Abdul & Afeganistão & 23-mar-03 & Afeganistão \\
\hline 144 & Rahmatullah & Afeganistão & 15-dez-06 & Afeganistão \\
\hline 145 & Rasool, Habib & Afeganistão & 19-jul-05 & Afeganistão \\
\hline 146 & Rasoul, Abdullah Gulam & Afeganistão & 12-dez-07 & Afeganistão \\
\hline 147 & Raz, Mohammed & Afeganistão & 16-jul-03 & Afeganistão \\
\hline 148 & Razak, Abdul & Afeganistão & 7 -ago-07 & Afeganistão \\
\hline 149 & Razaq, Abdul & Afeganistão & 15 -set-02 & Afeganistão \\
\hline 150 & Razzaq, Abdul & Afeganistão & 12-dez-07 & Afeganistão \\
\hline 151 & Ruhani, Gholam & Afeganistão & 12-dez-07 & Afeganistão \\
\hline 152 & Sadik, Mahmud & Afeganistão & 16-jul-03 & Afeganistão \\
\hline 153 & Sadiq, Mohammed & Afeganistão & 28 -out-02 & Afeganistão \\
\hline 154 & Salaam, Abdul & Afeganistão & 8-fev-06 & Afeganistão \\
\hline 155 & Samad, Abdul & Afeganistão & 18 -set-04 & Afeganistão \\
\hline 156 & Sangaryar, Rahmatullah & Afeganistão & 30 -abr-08 & Afeganistão \\
\hline 157 & Sarajuddin, Abib & Afeganistão & 11-out-06 & Afeganistão \\
\hline 158 & Sargidene, Mohammed & Afeganistão & 23-mar-03 & Afeganistão \\
\hline 159 & Sarwar, Kari Mohammed & Afeganistão & 16-jul-03 & Afeganistão \\
\hline 160 & Sayed, Abdul Hadi Muhamed Rasul & Afeganistão & 18-nov-03 & Afeganistão \\
\hline 161 & Shah, Nahir & Afeganistão & 2-nov-07 & Afeganistão \\
\hline 162 & Shah, Qalandar & Afeganistão & 18 -abr-05 & Afeganistão \\
\hline 163 & Shah, Solaiman Dur Mohammed & Afeganistão & 23-mar-03 & Afeganistão \\
\hline 164 & Shah, Zakim & Afeganistão & 14-mar-04 & Afeganistão \\
\hline 165 & $\begin{array}{l}\text { Shaheen Naqeebyllah, Shahwali, Zair } \\
\text { Mohammed }\end{array}$ & Afeganistão & 18 -abr-05 & Afeganistão \\
\hline 166 & Shahzada, Haji & Afeganistão & 18 -abr-05 & Afeganistão \\
\hline 167 & Sharbat & Afeganistão & 8-fev-06 & Afeganistão \\
\hline
\end{tabular}




\begin{tabular}{|c|c|c|c|c|}
\hline \multicolumn{5}{|c|}{$\begin{array}{l}\text { Prisioneiros transferidos da Prisão de Guantánamo (Cuba) para outros países. } \\
\text { (Até 01 de Junho de 2009) }\end{array}$} \\
\hline $\mathbf{N}^{\mathbf{o}}$ & Nome & Naciolidade & $\begin{array}{c}\text { Data da } \\
\text { Transfer. }\end{array}$ & Transferido para \\
\hline 168 & Sharif, Mohammed & Afeganistão & 7-ago-07 & Afeganistão \\
\hline 169 & Tahir, Mohammed & Afeganistão & 9-mai-03 & Afeganistão \\
\hline 170 & Torjan, Shaibjan & Afeganistão & 23-mar-03 & Afeganistão \\
\hline 171 & Tukhi, Aminullah Baryalai & Afeganistão & 12-dez-07 & Afeganistão \\
\hline 172 & Ullah, Amin & Afeganistão & 7-ago-07 & Afeganistão \\
\hline 173 & Ullah, Asad & Afeganistão & 28-jan-04 & Afeganistão \\
\hline 174 & Ullah, Faiz & Afeganistão & 11-out-06 & Afeganistão \\
\hline 175 & Ullah, Naqib & Afeganistão & 28-jan-04 & Afeganistão \\
\hline 176 & Ullah, Noor Habib & Afeganistão & 16-jul-03 & Afeganistão \\
\hline 177 & Ullah, Shams & Afeganistão & 11-out-06 & Afeganistão \\
\hline 178 & Wahab, Abdul & Afeganistão & 31-ago-08 & Afeganistão \\
\hline 179 & Waheed, Abdul & Afeganistão & 16-jul-03 & Afeganistão \\
\hline 180 & Wakil, Haji Sahib Rohullah & Afeganistão & 30 -abr-08 & Afeganistão \\
\hline 181 & Wali, Badshah & Afeganistão & 23-mar-03 & Afeganistão \\
\hline 182 & Walijan, Neyaz & Afeganistão & 23-mar-03 & Afeganistão \\
\hline 183 & Wazir, Abdullah & Afeganistão & 12-dez-07 & Afeganistão \\
\hline 184 & Wazir, Haji Mohammed & Afeganistão & 14-mar-04 & Afeganistão \\
\hline 185 & Wazir, Padsha & Afeganistão & 18 -abr-05 & Afeganistão \\
\hline 186 & Yacoub, Mohammed & Afeganistão & 7-ago-07 & Afeganistão \\
\hline 187 & Yakubi, Mohammed Mussa & Afeganistão & 26-jul-08 & Afeganistão \\
\hline 188 & Yaqub, Mohammed Yusif & Afeganistão & 9-mai-03 & Afeganistão \\
\hline 189 & Yar, Kushky & Afeganistão & 8 -fev-06 & Afeganistão \\
\hline 190 & Yousef, Mohammed Haji & Afeganistão & 18-nov-03 & - \\
\hline 191 & Zaeef, Abdul Salam & Afeganistão & 11 -set-05 & Afeganistão \\
\hline 192 & Zahor, Abdul & Afeganistão & 15-dez-06 & Afeganistão \\
\hline 193 & Zaman, Gul & Afeganistão & 18 -abr-05 & Afeganistão \\
\hline 194 & Zaman, Khan & Afeganistão & 8-fev-06 & Afeganistão \\
\hline 195 & Zumarikourt, Aziz Khan Ali Khan & Afeganistão & 14-mar-04 & Afeganistão \\
\hline 196 & Abdenour, Sameur & Algéria & 19-dez-07 & Reino Unido \\
\hline 197 & Ahmed, Labed & Algéria & 10-nov-08 & Algéria \\
\hline 198 & al Qadir, Mohammed Abd Al & Algéria & 25-ago-08 & Algéria \\
\hline 199 & Ameur, Mammar & Algéria & 6-out-08 & Algéria \\
\hline 200 & Boucetta, Fethi & Algéria & 17-nov-06 & Albania \\
\hline 201 & Boumediene, Lakhdar & Algéria & 15-mai-09 & França \\
\hline 202 & Feghoul, Abdulli & Algéria & 25-ago-08 & Algéria \\
\hline 203 & Hamlily, Mustafa Ahmed & Algéria & 2-jul-08 & Algéria \\
\hline 204 & Houari, Abdul Raham & Algéria & 2-jul-08 & Algéria \\
\hline 205 & Huwari, Soufian Abar & Algéria & 10-nov-08 & Algéria \\
\hline 206 & Said, Hassan Mujamma Rabai & Algéria & 17-jan-09 & Algéria \\
\hline 207 & Ait Idr, Mustafa & $\begin{array}{l}\text { Algéria, Bósnia } \\
\text { e Herzegovina }\end{array}$ & 16-dez-08 & $\begin{array}{l}\text { Bósnia And } \\
\text { Herzegovina }\end{array}$ \\
\hline 208 & Boudella, Hadj & $\begin{array}{l}\text { Algéria, Bósnia } \\
\text { e Herzegovina }\end{array}$ & 16-dez-08 & $\begin{array}{c}\text { Bósnia And } \\
\text { Herzegovina }\end{array}$ \\
\hline 209 & Nechle, Mohammed & $\begin{array}{l}\text { Algéria, Bósnia } \\
\text { e Herzegovina }\end{array}$ & 16-dez-08 & $\begin{array}{c}\text { Bósnia And } \\
\text { Herzegovina }\end{array}$ \\
\hline 210 & Habib, Mamdouh Ibrahim Ahmed & Australia & 27-jan-08 & Australia \\
\hline 211 & Hicks, David $^{189}$ & Australia & 18-mai-07 & Australia \\
\hline
\end{tabular}

${ }^{189}$ David Hicks, australiano, foi capturado no Afeganistão em dezembro de 2001. Foi o primeiro suspeito de terrorismo a ser acusado e julgado nos novos tribunais especiais de Guantánamo, se declarou culpado, foi condenado a 7 anos de prisão. Como ja havia ficado quase 6 anos em Guantánamo, foi transferido para a prisao Yatala Labour em Adelaide, no sul da Austrália. Teve 9 meses da sentença suspensos, sendo libertado em dezembro de 2007. BBC BRASIL. 


\begin{tabular}{|c|c|c|c|c|}
\hline \multicolumn{5}{|c|}{$\begin{array}{l}\text { Prisioneiros transferidos da Prisão de Guantánamo (Cuba) para outros países. } \\
\text { (Até 01 de Junho de 2009) }\end{array}$} \\
\hline $\mathbf{N}^{\mathbf{0}}$ & Nome & Naciolidade & $\begin{array}{l}\text { Data da } \\
\text { Transfer. }\end{array}$ & Transferido para \\
\hline 212 & $\begin{array}{l}\text { al Balushi, Salah Abdul Rasul Ali } \\
\text { Abdul Rahman }\end{array}$ & Bahrain & 11-out-06 & Bahrain \\
\hline 213 & $\begin{array}{l}\text { al Dosari, Juma Mohammed Abdul } \\
\text { Latif }\end{array}$ & Bahrain & 15-jul-07 & Arábia Saudita \\
\hline 214 & $\begin{array}{l}\text { al Khalifa, Sheikh Salman Ebrahim } \\
\text { Mohamed Ali }\end{array}$ & Bahrain & 4-nov-05 & Bahrain \\
\hline 215 & al Murbati, Issa Ali Abdullah & Bahrain & 7-ago-07 & Bahrain \\
\hline 216 & al Noaimi, Abdullah & Bahrain & 4-nov-05 & Bahrain \\
\hline 217 & al Wadi, Adil Kamil Abdullah & Bahrain & 4-nov-05 & Bahrain \\
\hline 218 & Hashem, Mubarak Hussain Bin Abul & Bangladesh & 15-dez-06 & Bangladesh \\
\hline 219 & Sen, Mesut & Bélgica & 25 -abr-05 & Bélgica \\
\hline 220 & Zemmori, Mosa Zi & Bélgica & 25 -abr- 05 & Bélgica \\
\hline 221 & Khadr, Abdurahman & Canada & 18-nov-03 & $\begin{array}{c}\text { Bósnia e } \\
\text { Herzegovina }\end{array}$ \\
\hline 222 & Abdulhehim, Adel & China & 5-mai-06 & Albania \\
\hline 223 & Adil, Ahmed & China & 5-mai-06 & Albania \\
\hline 224 & Ayub, Haji Mohammed & China & 5-mai-06 & Albania \\
\hline 225 & Basit, Akhdar Qasem & China & 5-mai-06 & Albania \\
\hline 226 & Qasim, Abu Bakr & China & 5-mai-06 & Albania \\
\hline 227 & Abderrahmane, Slimane Hadj & Dinamarca & 24-fev-04 & Dinamarca \\
\hline 228 & al Waleeli, Fael Roda & Egito & 1-jul-03 & - \\
\hline 229 & Allaithy, Sami Abdul Aziz Salim & Egito & 20 -set-05 & Egito \\
\hline 230 & Saleem, Allah Muhammed & Egito & 17-nov-06 & Albania \\
\hline 231 & Mohamed, Binyam & Etiopia & 23-fev-09 & Reino Unido \\
\hline 232 & Benchellali, Mourad & França & 26-jul-04 & França \\
\hline 233 & Kanouni, Imad Achab & França & 27-jul-04 & França \\
\hline 234 & Khalid, Ridouane & França & 7-mar-05 & França \\
\hline 235 & Mustafa, Khaled Ben & França & 7-mar-05 & França \\
\hline 236 & Patel, Mustaq Ali & França & 7-mar-05 & França \\
\hline 237 & Sassi, Nizar & França & 26-jul-04 & França \\
\hline 238 & Yadel, Brahim & França & 26-jul-04 & França \\
\hline 239 & Bamari, Bakhtiar & Irã & 31-mar-04 & Afeganistão \\
\hline 240 & Kurd, Mohamed Anwar & Irã & 19-ago-05 & Irã \\
\hline 241 & Muhammed, Abdul Majid & Irã & 11-out-06 & Irã \\
\hline 242 & al Karim, Arkan Mohammad Ghafil & Iraque & 17-jan-09 & Iraque \\
\hline 243 & al Naely, Abbas Habid Rumi & Iraque & 17-jan-09 & Iraque \\
\hline 244 & al Rawi, Bisher Amin Khalil & Iraque & 30-mar-07 & Reino Unido \\
\hline 245 & al Tamimi, Haydar Jabbar Hafez & Iraque & 31-mar-04 & Iraque \\
\hline 246 & Mohhamed, Sohab Mahud & Iraque & 31-mar-04 & Iraque \\
\hline 247 & Said, Hassan Abdul & Iraque & 17-jan-09 & Iraque \\
\hline 248 & $\begin{array}{l}\text { Tayeea, Ali Abdul Motalib Awayd } \\
\text { Hassan Al }\end{array}$ & Iraque & 17-jan-09 & Iraque \\
\hline 249 & $\begin{array}{l}\text { Abdul Hamid, Hassan Khalil } \\
\text { Mohamoud }\end{array}$ & Jordania & 18-nov-03 & - \\
\hline 250 & $\begin{array}{l}\text { Abdul Wahab al Asmr, Khalid } \\
\text { Mahomoud }\end{array}$ & Jordania & 20-jul-05 & Jordania \\
\hline 251 & Ahmad, Osam Abdul Rahan & Jordania & 31-mar-04 & Jordania \\
\hline 252 & al Amrani, Ayman Mohammad Silman & Jordania & 30-nov-03 & - \\
\hline
\end{tabular}

Guantánamo: Único condenado por terrorismo é solto. O Estadão, 29 dez. 2007. Disponível em <http://www.estadao.com.br/noticias/geral,Guantánamo-unico-condenado-por-terrorismo-esolto, 102319,0.htm>. Acesso em 15 abr. 2009. 


\begin{tabular}{|c|c|c|c|c|}
\hline \multicolumn{5}{|c|}{$\begin{array}{l}\text { Prisioneiros transferidos da Prisão de Guantánamo (Cuba) para outros países. } \\
\text { (Até } 01 \text { de Junho de 2009) }\end{array}$} \\
\hline $\mathbf{N}^{\mathbf{o}}$ & Nome & Naciolidade & $\begin{array}{c}\text { Data da } \\
\text { Transfer. }\end{array}$ & Transferido para \\
\hline 253 & al Husayn, Zaid Muhamamd Sa'ad & Jordania & 9-nov-07 & Arábia Saudita \\
\hline 254 & El Banna, Jamil & Jordania & 19-dez-07 & Reino Unido \\
\hline 255 & Kabir, Usama Hassan Ahmed Abu & Jordania & 2-nov-07 & Jordania \\
\hline 256 & Suleyman, Ahmed Hassan Jamil & Jordania & 2-nov-07 & Jordania \\
\hline 257 & Zeidan, Ibrahim Mahdi Achmed & Jordania & 2-nov-07 & Jordania \\
\hline 258 & Batayev, Ilkham Turdbyavich & Cazaquistão & 15-dez-06 & Cazaquistão \\
\hline 259 & Kerimbakiev, Abdulrahim & Cazaquistão & 31-out-08 & Cazaquistão \\
\hline 260 & Magrupov, Abdullah Tohtasinovich & Cazaquistão & 18-dez-06 & Cazaquistão \\
\hline 261 & al Ajmi, Abdallah Saleh Ali & Kuwait & 2-nov-05 & Kuwait \\
\hline 262 & al Azmi, Saad Madi Saad & Kuwait & 2-nov-05 & Kuwait \\
\hline 263 & al Dehani, Mohammad Finaytal & Kuwait & 2-nov-05 & Kuwait \\
\hline 264 & al Shammari, Abdulaziz Sayer Owain & Kuwait & 2-nov-05 & Kuwait \\
\hline 265 & al Zamel, Adel Zamel Abd al Mahsen & Kuwait & 2 -nov-05 & Kuwait \\
\hline 266 & Amin, Omar Rajab & Kuwait & $14-$ set-06 & Kuwait \\
\hline 267 & Amtiri, Nasser Najiri & Kuwait & 16 -jan-05 & Kuwait \\
\hline 268 & Kamel, Abdullah Kamel Abudallah & Kuwait & 14 -set-06 & Kuwait \\
\hline 269 & $\begin{array}{l}\text { al Futri, Muhammad Abd Allah Manur } \\
\text { Safrani }\end{array}$ & Líbia & 15-dez-06 & Líbia \\
\hline 270 & $\begin{array}{l}\text { Bin Qumu, Abu Sufian Ibrahim Ahmed } \\
\text { Hamuda }\end{array}$ & Líbia & 28 -set-07 & Líbia \\
\hline 271 & Deghayes, Omar Amer & Líbia & 19-dez-07 & Reino Unido \\
\hline 272 & Fauzee, Ibrahim & Maldivas & 11-mar-05 & Maldivas \\
\hline 273 & Mohammad, Mohammad Lameen Sidi & Mauritânia & & Mauritânia \\
\hline 274 & al Shakouri, Radwan & Marrocos & 31-jul-04 & Marrocos \\
\hline 275 & Awzar, Mohamed Ibrahim & Marrocos & 31-jul-04 & Marrocos \\
\hline 276 & Ben Moujan, Muhammad & Marrocos & 11-out-06 & Marrocos \\
\hline 277 & Boujaadia, Said & Marrocos & 30 -abr-08 & Marrocos \\
\hline 278 & Hassan, Muhammad Hussein Ali & Marrocos & 7 -fev-06 & Marrocos \\
\hline 279 & Ikassrin, Laacin & Marrocos & 18 -jul-05 & Espanha \\
\hline 280 & Laalami, Mohammed Souleimani & Marrocos & 7-fev-06 & Marrocos \\
\hline 281 & Lahassihi, Najib Mohammad & Marrocos & 7-fev-06 & Marrocos \\
\hline 282 & Mizouz, Mohammed & Marrocos & 31-jul-04 & Marrocos \\
\hline 283 & Rashidi, Ahmed & Marrocos & $24-a b r-07$ & Marrocos \\
\hline 284 & Shakaran, Ibrahim Bin & Marrocos & 31-jul-04 & Marrocos \\
\hline 285 & Tabarak, Abdullah & Marrocos & 1-jul-03 & Marrocos \\
\hline 286 & Dergoul, Tarek & $\begin{array}{l}\text { Marrocos, } \\
\text { Reino Unido }\end{array}$ & 9-mar-04 & Reino Unido \\
\hline 287 & Abas, Mohammad & Paquistão & 14-mar-04 & Paquistão \\
\hline 288 & Ahmad, Bashir & Paquistão & 17 -set-04 & Paquistão \\
\hline 289 & Ahmad, Sultan & Paquistão & 17 -set-04 & Paquistão \\
\hline 290 & Ahmed, Ali & Paquistão & $16-$ jul-03 & Paquistão \\
\hline 291 & Ahmed, Saghir & Paquistão & 17 -set-04 & Paquistão \\
\hline 292 & Ahmed, Sar Faraz & Paquistão & 17 -set-04 & Paquistão \\
\hline 293 & Akbar, Mohammed & Paquistão & 17 -set-04 & Paquistão \\
\hline 294 & Ali, Said Saim & Paquistão & 17 -set-04 & Paquistão \\
\hline 295 & Alikhel, Sha Mohammed & Paquistão & 9-mai-03 & Paquistão \\
\hline 296 & Amin, Aminulla & Paquistão & 17 -set-04 & Paquistão \\
\hline 297 & Ansar, Mohammed & Paquistão & $16-$ jul-03 & Paquistão \\
\hline 298 & Anwar, Mohammed & Paquistão & 17 -set-04 & Paquistão \\
\hline 299 & Ashraf, Mohammed & Paquistão & 17 -set-04 & Paquistão \\
\hline 300 & Ayub, Haseeb & Paquistão & 17 -set-04 & Paquistão \\
\hline 301 & Ayubi, Salahodin & Paquistão & 17 -set-04 & Paquistão \\
\hline 302 & Fazaldad & Paquistão & 17 -set-04 & Paquistão \\
\hline
\end{tabular}




\begin{tabular}{|c|c|c|c|c|}
\hline \multicolumn{5}{|c|}{$\begin{array}{l}\text { Prisioneiros transferidos da Prisão de Guantánamo (Cuba) para outros países. } \\
\text { (Até 01 de Junho de 2009) }\end{array}$} \\
\hline $\mathbf{N}^{\mathbf{0}}$ & Nome & Naciolidade & $\begin{array}{l}\text { Data da } \\
\text { Transfer. }\end{array}$ & Transferido para \\
\hline 303 & Fiyatullah, Kay & Paquistão & 17 -set-04 & Paquistão \\
\hline 304 & Hafez, Khalil Rahman & Paquistão & 17 -set-04 & Paquistão \\
\hline 305 & Ijaz, Mohammed & Paquistão & 17 -set-04 & Paquistão \\
\hline 306 & Ilyas, Mohammad & Paquistão & 17 -set-04 & Paquistão \\
\hline 307 & Iqbal, Faik & Paquistão & 16-jul-03 & Paquistão \\
\hline 308 & Iqbal, Zafar & Paquistão & 17 -set-04 & Paquistão \\
\hline 309 & Irfan, Mohammed & Paquistão & 17 -set-04 & Paquistão \\
\hline 310 & Irfan, Mohammed & Paquistão & 17 -set-04 & Paquistão \\
\hline 311 & Ishaq, Mohammed & Paquistão & 18-nov-03 & Paquistão \\
\hline 312 & Khan, Bacha & Paquistão & 17 -set-04 & Paquistão \\
\hline 313 & Khan, Ejaz Ahmad & Paquistão & 18-nov-03 & Paquistão \\
\hline 314 & Khan, Hamood Ullah & Paquistão & 17 -set-04 & Paquistão \\
\hline 315 & Khan, Isa & Paquistão & 17 -set-04 & Paquistão \\
\hline 316 & Khan, Mohammad Kashef & Paquistão & 16-jul-03 & Paquistão \\
\hline 317 & Khan, Muhammed Ijaz & Paquistão & 17 -set-04 & Paquistão \\
\hline 318 & Khan, Tariq & Paquistão & 16-jul-03 & Paquistão \\
\hline 319 & Khan, Tila Mohammed & Paquistão & 18-nov-03 & Paquistão \\
\hline 320 & Manzu, Hafice Leqeat & Paquistão & 18-nov-03 & Paquistão \\
\hline 321 & Mehmood, Majid & Paquistão & 18-nov-03 & Paquistão \\
\hline 322 & Mohammad, Tarik & Paquistão & 30-nov-03 & - \\
\hline 323 & Mohammed, Ali & Paquistão & 14-mar-04 & Paquistão \\
\hline 324 & Mohhamed, Hanif & Paquistão & 17 -set-04 & Paquistão \\
\hline 325 & Mowla, Abdul & Paquistão & 16-jul-03 & Paquistão \\
\hline 326 & Muhammad Saad Iqbal & Paquistão & 31-ago-08 & Paquistão \\
\hline 327 & Nafeesi, Abdul Satar & Paquistão & 17 -set-04 & Paquistão \\
\hline 328 & Naseer, Munir Bin & Paquistão & 30-nov-03 & Paquistão \\
\hline 329 & Noman, Mohammed & Paquistão & 17 -set-04 & Paquistão \\
\hline 330 & Omar, Mohammed & Paquistão & 17 -set-04 & Paquistão \\
\hline 331 & Rafiq, Mohammed & Paquistão & 17 -set-04 & Paquistão \\
\hline 332 & Rahman, Shed Abdur & Paquistão & 11-mar-05 & Paquistão \\
\hline 333 & Raza, Abid & Paquistão & 17 -set-04 & Paquistão \\
\hline 334 & Raza, Mohammed Arshad & Paquistão & 17 -set-04 & Paquistão \\
\hline 335 & Raziq, Abdul & Paquistão & $16-j u l-03$ & Paquistão \\
\hline 336 & Sadiqi, Abdul Halim & Paquistão & 11-out-06 & Paquistão \\
\hline 337 & Saeed, Hafiz Ihsan & Paquistão & 17 -set-04 & Paquistão \\
\hline 338 & Safollah, Ghaser Zaban & Paquistão & 16-jul-03 & Paquistão \\
\hline 339 & Sanghir, Mohammad & Paquistão & 28 -out- 02 & Paquistão \\
\hline 340 & Sattar, Abdul & Paquistão & 17 -set-04 & Paquistão \\
\hline 341 & Sayed, Mohammed & Paquistão & 17 -set-04 & Paquistão \\
\hline 342 & Sultan, Zahid & Paquistão & 17 -set-04 & Paquistão \\
\hline 343 & Tariq, Mohammed & Paquistão & 17 -set-04 & Paquistão \\
\hline 344 & Ul Haq, Israr & Paquistão & 14-mar-04 & Paquistão \\
\hline 345 & Ul Shah, Zia & Paquistão & 11-out-06 & Paquistão \\
\hline 346 & Ullah, Asad & Paquistão & 16-jul-03 & Paquistão \\
\hline 347 & Urayman, Sajin & Paquistão & 16-jul-03 & Paquistão \\
\hline 348 & Usman, Shabidzada & Paquistão & 9-mai-03 & Paquistão \\
\hline 349 & Wali, Jihan & Paquistão & 9-mai-03 & Paquistão \\
\hline 350 & Hudin, Salah & $\begin{array}{c}\text { Paquistão, } \\
\text { Afeganistão }\end{array}$ & 16-jul-03 & - \\
\hline 351 & al Deen, Jamal Muhammad & $\begin{array}{l}\text { Paquistão, } \\
\text { Bangladesh }\end{array}$ & 16-jul-03 & Paquistão \\
\hline 352 & $\begin{array}{l}\text { al Marri, Jaralla Saleh Mohammed } \\
\text { Kahla }\end{array}$ & Qatar & 26-jul-08 & Qatar \\
\hline
\end{tabular}




\begin{tabular}{|c|c|c|c|c|}
\hline \multicolumn{5}{|c|}{$\begin{array}{l}\text { Prisioneiros transferidos da Prisão de Guantánamo (Cuba) para outros países. } \\
\text { (Até 01 de Junho de 2009) }\end{array}$} \\
\hline $\mathbf{N}^{\mathbf{0}}$ & Nome & Naciolidade & $\begin{array}{l}\text { Data da } \\
\text { Transfer. }\end{array}$ & Transferido para \\
\hline 353 & Akhmyarov, Rustam & Rússia & $27-f e v-04$ & Rússia \\
\hline 354 & Gumarov, Ravil Shafeyavich & Rússia & $27-f e v-04$ & Rússia \\
\hline 355 & Ishmurat, Timur Ravilich & Rússia & $27-f e v-04$ & Rússia \\
\hline 356 & Kudayev, Rasul & Rússia & $27-f e v-04$ & Rússia \\
\hline 357 & Odizhev, Ruslan & Rússia & 27-fev-04 & Rússia \\
\hline 358 & Sharipov, Almasm Rabilavich & Rússia & 27-fev-04 & Rússia \\
\hline 359 & Vahitov, Aiat Nasimovich & Rússia & 27-fev-04 & Rússia \\
\hline 360 & Abdel Aziz, Abdullah Muhammed & Arábia Saudita & 13-dez-06 & Arábia Saudita \\
\hline 361 & Ahmed, Abdul Rahman Uthman & Arábia Saudita & 18-mai-06 & Arábia Saudita \\
\hline 362 & al Anazi, Sultan Sari Sayel & Arábia Saudita & 13-dez-06 & Arábia Saudita \\
\hline 363 & al Ansari, Faris Muslim & Arábia Saudita & 28-dez-07 & Arábia Saudita \\
\hline 364 & al Asiri, Turki Mash Awi Zayid & Arábia Saudita & 9-nov-07 & Arábia Saudita \\
\hline 365 & al Atabi, Bijad Thif Allah & Arábia Saudita & 15 -jul-07 & Arábia Saudita \\
\hline 366 & al Awfi, Mazin Salih Musaid & Arábia Saudita & 15 -jul-07 & Arábia Saudita \\
\hline 367 & al Awfi, Muhammad & Arábia Saudita & 9-nov-07 & Arábia Saudita \\
\hline 368 & $\begin{array}{l}\text { al Baddah, Abdul Aziz Abdul Rahman } \\
\text { Abdul Aziz }\end{array}$ & Arábia Saudita & 24-jun-06 & Arábia Saudita \\
\hline 369 & al Barakat, Khalid Hassan Husayn & Arábia Saudita & 5-set-07 & Arábia Saudita \\
\hline 370 & $\begin{array}{l}\text { al Bawardi, Khalid Saud Abd al } \\
\text { Rahman }\end{array}$ & Arábia Saudita & 9-nov-07 & Arábia Saudita \\
\hline 371 & al Bidna, Saad Ibraham Saad & Arábia Saudita & 24-jun-06 & Arábia Saudita \\
\hline 372 & al Farha, Said Ali & Arábia Saudita & 13-dez-06 & Arábia Saudita \\
\hline 373 & al Fayfi, Jabir Jubran & Arábia Saudita & 13-dez-06 & Arábia Saudita \\
\hline 374 & al Fouzan, Fahd Muhammed Abdullah & Arábia Saudita & 5-set-07 & Arábia Saudita \\
\hline 375 & al Frih, Majed Hamad & Arábia Saudita & 13-dez-06 & Arábia Saudita \\
\hline 376 & al Ghatani, Khalid Malu Shia & Arábia Saudita & 28-dez-07 & Arábia Saudita \\
\hline 377 & al Hajjaji, al Silm Haji Hajjaj Awwad & Arábia Saudita & 13-dez-06 & Arábia Saudita \\
\hline 378 & al Harazi, Fahed & Arábia Saudita & 5-set-07 & Arábia Saudita \\
\hline 379 & al Harbi, Ghanim Abdul Rahman & Arábia Saudita & $15-$ jul-07 & Arábia Saudita \\
\hline 380 & $\begin{array}{l}\text { al Harbi, Majid Abdallah Husayn } \\
\text { Muhammad al Samluli }\end{array}$ & Arábia Saudita & $20-\mathrm{fev}-07$ & Arábia Saudita \\
\hline 381 & al Harbi, Mohammed Abdullah & Arábia Saudita & 20-fev-07 & Arábia Saudita \\
\hline 382 & al Harbi, Salim Suliman & Arábia Saudita & 13-dez-06 & Arábia Saudita \\
\hline 383 & al Harbi, Tariqe Shallah Hassan & Arábia Saudita & 24-jun-06 & Arábia Saudita \\
\hline 384 & al Hataybi, Abdul Rahman Nashi Badi & Arábia Saudita & 28-dez-07 & Arábia Saudita \\
\hline 385 & al Hizani, Abd & Arábia Saudita & 15-jul-07 & Arábia Saudita \\
\hline 386 & al Hubayshi, Khalid Sulayman Jaydh & Arábia Saudita & 22-jul-05 & Arábia Saudita \\
\hline 387 & al Jabri, Bandar Ahmad Mubarak & Arábia Saudita & $15-\mathrm{jul}-07$ & Arábia Saudita \\
\hline 388 & al Jadan, Humud Dakhil Humud Said & Arábia Saudita & $15-$ jul-07 & Arábia Saudita \\
\hline 389 & al Joudi, Majeed Abdullah & Arábia Saudita & $20-\mathrm{fev}-07$ & Arábia Saudita \\
\hline 390 & $\begin{array}{l}\text { al Juaid, Abdul Rahman Owaid } \\
\text { Mohammad }\end{array}$ & Arábia Saudita & 15-jul-07 & Arábia Saudita \\
\hline 391 & al Juhani, Muhamad Naji Subhi & Arábia Saudita & 15 -jul-07 & Arábia Saudita \\
\hline 392 & al Jutayli, Fahd Salih Sulayman & Arábia Saudita & 18-mai-06 & Arábia Saudita \\
\hline 393 & al Kabi, Jamil Ali & Arábia Saudita & 28-dez-07 & Arábia Saudita \\
\hline 394 & al Khaldi, Abdul Aziz Saad & Arábia Saudita & 5-set-07 & Arábia Saudita \\
\hline 395 & al Khalif, Hani Saiid Mohammad & Arábia Saudita & 9-nov-07 & Arábia Saudita \\
\hline 396 & al Khathami, Saleh Ali Jaid & Arábia Saudita & 24-jun-06 & Arábia Saudita \\
\hline 397 & al Kurash, Muhammad Abd al Rahman & Arábia Saudita & 15 -jul-07 & Arábia Saudita \\
\hline 398 & $\begin{array}{l}\text { al Mahayawi, Saud Dakhil Allah } \\
\text { Muslih }\end{array}$ & Arábia Saudita & 15 -jul-07 & Arábia Saudita \\
\hline 399 & al Malki, Saed Khatem & Arábia Saudita & 18-mai-06 & Arábia Saudita \\
\hline 400 & al Matrafi, Abdallah Aiza & Arábia Saudita & 28-dez-07 & Arábia Saudita \\
\hline
\end{tabular}




\begin{tabular}{|c|c|c|c|c|}
\hline \multicolumn{5}{|c|}{$\begin{array}{l}\text { Prisioneiros transferidos da Prisão de Guantánamo (Cuba) para outros países. } \\
\text { (Até 01 de Junho de 2009) }\end{array}$} \\
\hline $\mathbf{N}^{\mathbf{o}}$ & Nome & Naciolidade & $\begin{array}{l}\text { Data da } \\
\text { Transfer. }\end{array}$ & Transferido para \\
\hline 401 & $\begin{array}{l}\text { al Morghi, Khalid Abdallah Abdel } \\
\text { Rahman }\end{array}$ & Arábia Saudita & 18-mai-06 & Arábia Saudita \\
\hline 402 & $\begin{array}{l}\text { al Mousa, Abdul Hakim Abdul Rahman } \\
\text { Abduaziz }\end{array}$ & Arábia Saudita & 28-dez-07 & Arábia Saudita \\
\hline 403 & al Muri, Khalid Rashd Ali & Arábia Saudita & 18-mai-06 & Arábia Saudita \\
\hline 404 & $\begin{array}{l}\text { al Nasir, Abd al Aziz Muhammad } \\
\text { Ibrahim }\end{array}$ & Arábia Saudita & 13-dez-06 & Arábia Saudita \\
\hline 405 & al Nasir, Faizal Saha & Arábia Saudita & 20-fev-07 & Arábia Saudita \\
\hline 406 & al Nasir, Ibrahim Muhammed Ibrahim & Arábia Saudita & 24-jun-06 & Arábia Saudita \\
\hline 407 & al Nurr, Anwar & Arábia Saudita & 13-dez-06 & Arábia Saudita \\
\hline 408 & al Nusayri, Adil Uqla Hassan & Arábia Saudita & 18-mai-06 & Arábia Saudita \\
\hline 409 & al Omairah, Othman Ahmed Othman & Arábia Saudita & 24-jun-06 & Arábia Saudita \\
\hline 410 & al Oshan, Saleh Abdall & Arábia Saudita & $24-$ jul-05 & Arábia Saudita \\
\hline 411 & al Otaibi, Nawaf Fahad & Arábia Saudita & 18-mai-06 & Arábia Saudita \\
\hline 412 & al Qahtani, Abdullah Hamid & Arábia Saudita & 18-mai-06 & Arábia Saudita \\
\hline 413 & al Qahtani, Jabir Hasan Muhamed & Arábia Saudita & 9-nov-07 & Arábia Saudita \\
\hline 414 & al Qurayshi, Majid Aydha Muhammad & Arábia Saudita & 20-fev-07 & Arábia Saudita \\
\hline 415 & al Qurbi, Mohammed Mubarek Salah & Arábia Saudita & 5-set-07 & Arábia Saudita \\
\hline 416 & al Rabiesh, Yusef Abdullah Saleh & Arábia Saudita & 13-dez-06 & Arábia Saudita \\
\hline 417 & al Rashid, Mesh Arsad & Arábia Saudita & 28-dez-07 & Arábia Saudita \\
\hline 418 & al Rushaydan, Abdallah Ibrahim & Arábia Saudita & 18-mai-06 & Arábia Saudita \\
\hline 419 & al Samiri, Bader al Bakri & Arábia Saudita & 5-set-07 & Arábia Saudita \\
\hline 420 & al Sehli, Ibrahim Daif Allah Neman & Arábia Saudita & 18-mai-06 & Arábia Saudita \\
\hline 421 & al Shabani, Fahd Abdallah Ibrahim & Arábia Saudita & 14-mai-03 & Arábia Saudita \\
\hline 422 & al Shamaree, Zaban Thaaher Zaban & Arábia Saudita & 5-set-07 & Arábia Saudita \\
\hline 423 & $\begin{array}{l}\text { al Sharakh, Abdulhadi Abdallah } \\
\text { Ibrahim }\end{array}$ & Arábia Saudita & 5 -set-07 & Arábia Saudita \\
\hline 424 & al Sharif, Fahd Umr Abd al Majid & Arábia Saudita & 9-nov-07 & Arábia Saudita \\
\hline 425 & $\begin{array}{l}\text { al Sharikh, Abd al Razaq Abdallah } \\
\text { Hamid Ibrahim }\end{array}$ & Arábia Saudita & 5 -set-07 & Arábia Saudita \\
\hline 426 & al Shedoky, Mishal Muhammad Rashid & Arábia Saudita & 14-mai-03 & Arábia Saudita \\
\hline 427 & al Shihri, Said Ali & Arábia Saudita & 9-nov-07 & Arábia Saudita \\
\hline 428 & al Shihri, Yussef Mohammed Mubarak & Arábia Saudita & 9-nov-07 & Arábia Saudita \\
\hline 429 & al Shimri, Maji Afas Radhi & Arábia Saudita & 4-nov-05 & Arábia Saudita \\
\hline 430 & al Siari, Abdullah Ali Salih al Debakha & Arábia Saudita & 13-dez-06 & Arábia Saudita \\
\hline 431 & al Sulami, Yahya Samil al Suwaymil & Arábia Saudita & $15-$ jul-07 & Arábia Saudita \\
\hline 432 & al Taibi, Rami Bin Said & Arábia Saudita & 5-set-07 & Arábia Saudita \\
\hline 433 & al Tayabi, Abdullah & Arábia Saudita & 15 -jul-07 & Arábia Saudita \\
\hline 434 & al Umar, Ibrahim Umar Ali & Arábia Saudita & 14-mai-03 & Arábia Saudita \\
\hline 435 & al Usaymi, Nayif Fahd Mutliq & Arábia Saudita & 28-dez-07 & Arábia Saudita \\
\hline 436 & al Utaybi, Abdullah Ali & Arábia Saudita & 28-dez-07 & Arábia Saudita \\
\hline 437 & $\begin{array}{l}\text { al Utaybi, Muhammad Surur } \\
\text { Dakhilallah }\end{array}$ & Arábia Saudita & 24-jun-06 & Arábia Saudita \\
\hline 438 & $\begin{array}{l}\text { al Uwaydha, Sultan Ahmed Dirdeer } \\
\text { Musa }\end{array}$ & Arábia Saudita & 9-nov-07 & Arábia Saudita \\
\hline 439 & al Wafti, Abdullah Abd al Muin & Arábia Saudita & 9-nov-07 & Arábia Saudita \\
\hline 440 & al Wahab, Musa Abed & Arábia Saudita & 24-jun-06 & Arábia Saudita \\
\hline 441 & al Zaharni, Khalid Mohammed & Arábia Saudita & $15-$ jul-07 & Arábia Saudita \\
\hline 442 & al Zahrani, Said Ibrahim Ramzi & Arábia Saudita & 15-jul-07 & Arábia Saudita \\
\hline 443 & al Zayla, Muhammed Yahia Mosin & Arábia Saudita & 13-dez-06 & Arábia Saudita \\
\hline 444 & Alhabiri, Mishal Awad Sayaf & Arábia Saudita & 19-jul-05 & Arábia Saudita \\
\hline 445 & Ali, Adnan Mohammed & Arábia Saudita & 18-mai-06 & Arábia Saudita \\
\hline 446 & Arbaysh, Ibrahim Sulayman & Arábia Saudita & 13-dez-06 & Arábia Saudita \\
\hline
\end{tabular}




\begin{tabular}{|c|c|c|c|c|}
\hline \multicolumn{5}{|c|}{$\begin{array}{l}\text { Prisioneiros transferidos da Prisão de Guantánamo (Cuba) para outros países. } \\
\text { (Até 01 de Junho de 2009) }\end{array}$} \\
\hline $\mathbf{N}^{\mathbf{0}}$ & Nome & Naciolidade & $\begin{array}{c}\text { Data da } \\
\text { Transfer. }\end{array}$ & Transferido para \\
\hline & Muhammad & & & \\
\hline 447 & Bahaysh, Salim Abdallah Said & Arábia Saudita & 5 -set-07 & Arábia Saudita \\
\hline 448 & Balkhair, Rashed Awad Khalaf & Arábia Saudita & 20 -fev-07 & Arábia Saudita \\
\hline 449 & Barayan, Majid Al & Arábia Saudita & 5-set-07 & Arábia Saudita \\
\hline 450 & Bukhary, Abdul Hakim & Arábia Saudita & 5 -set-07 & Arábia Saudita \\
\hline 451 & Ghetan, Abdul Salam & Arábia Saudita & 24-jun-06 & Arábia Saudita \\
\hline 452 & Hawsawi, Amran Baqur Mohammed & Arábia Saudita & 5 -set-07 & Arábia Saudita \\
\hline 453 & Ibrahim, Nayif Abdallah Ibrahim & Arábia Saudita & 9-nov-07 & Arábia Saudita \\
\hline 454 & Il Bhawith, Zaid Binsallah Mohammed & Arábia Saudita & 28-dez-07 & Arábia Saudita \\
\hline 455 & Jahdari, Ziad Said Farg & Arábia Saudita & 13-dez-06 & Arábia Saudita \\
\hline 456 & $\begin{array}{l}\text { Khowlan, Abdul Rahman Mohammed } \\
\text { Hussein }\end{array}$ & Arábia Saudita & 13-dez-06 & Arábia Saudita \\
\hline 457 & Makram, Murtadha al Said & Arábia Saudita & 9-nov-07 & Arábia Saudita \\
\hline 458 & Mohamed, Fahed Nasser & Arábia Saudita & 15-jul-07 & Arábia Saudita \\
\hline 459 & Mohammed, Ali Muhammed Nasir & Arábia Saudita & 28 -set-07 & Iêmen \\
\hline 460 & Mohammed, Salman Saad al Khadi & Arábia Saudita & 13-dez-06 & Arábia Saudita \\
\hline 461 & Musa Bin Ali Bin Said al Amri & Arábia Saudita & 5-set-07 & Arábia Saudita \\
\hline 462 & Nur, Yusif Khalil Abdallah & Arábia Saudita & 24-jun-06 & Arábia Saudita \\
\hline 463 & Qayed, Rashid Abdul Mosleh & Arábia Saudita & 24-jun-06 & Arábia Saudita \\
\hline 464 & Saleh Ganmi, Abdullah Muhammad & Arábia Saudita & 24-jun-06 & Arábia Saudita \\
\hline 465 & Sebai, Mohammed Jayed & Arábia Saudita & 18-mai-06 & Arábia Saudita \\
\hline 466 & $\begin{array}{l}\text { Sebaii, Abdel Hadi Mohammed Badan } \\
\text { al Sebaii }\end{array}$ & Arábia Saudita & 18-mai-06 & Arábia Saudita \\
\hline 467 & Shayban, Said Bezan Ashek & Arábia Saudita & 18-mai-06 & Arábia Saudita \\
\hline 468 & Shili, Ibrahim Rushdan Brayk al & Arábia Saudita & 14-mai-03 & Arábia Saudita \\
\hline 469 & $\begin{array}{l}\text { Subii, Nasir Maziyad Abdallah al } \\
\text { Qurayshi Al }\end{array}$ & Arábia Saudita & 20-fev-07 & Arábia Saudita \\
\hline 470 & Sultan, Faha & Arábia Saudita & 9-nov-07 & Arábia Saudita \\
\hline 471 & Thani, Abdallah Faris al Unazi & Arábia Saudita & 5-set-07 & Arábia Saudita \\
\hline 472 & Turkistani, Sadik Ahmad & Arábia Saudita & 24-jun-06 & Arábia Saudita \\
\hline 473 & Uwaydah, Rashid Awad Rashid Al & Arábia Saudita & 18-mai-06 & Arábia Saudita \\
\hline 474 & Wasim, Wasm Awwad Umar & Arábia Saudita & 24-jun-06 & Arábia Saudita \\
\hline 475 & Zahrani, Fawaz Abd al Aziz al & Arábia Saudita & 14-mai-03 & Arábia Saudita \\
\hline 476 & Hamdi, Yaser Esam & $\begin{array}{l}\text { Arábia Saudita, } \\
\text { Estados Unidos }\end{array}$ & 5 -abr-02 & Estados Unidos \\
\hline 477 & Abdallah, Muhamed Hussein & Somália & 4-nov-05 & Somália \\
\hline 478 & Ahmad, Ahmad Abd al Rahman & Espanha & 13-fev-04 & Espanha \\
\hline 479 & $\begin{array}{l}\text { al Amir Mahmoud, Amir Yakoub } \\
\text { Mohammed }\end{array}$ & Sudão & $30-a b r-08$ & Sudão \\
\hline 480 & al Hajj, Sami & Sudão & 30 -abr-08 & Sudão \\
\hline 481 & al Hassan, Mustafa Ibrahim Mustafa & Sudão & 6-out-08 & Sudão \\
\hline 482 & $\begin{array}{l}\text { Ali, Walid Mohammad Haj } \\
\text { Mohammad }\end{array}$ & Sudão & 30 -abr-08 & Sudão \\
\hline 483 & $\begin{array}{l}\text { Bani Amir, Salim Mahmoud Adem } \\
\text { Mohammed }\end{array}$ & Sudão & 12-dez-07 & Sudão \\
\hline 484 & Gadallah, Hammad Ali Amno & Sudão & 21-jul-05 & Sudão \\
\hline 485 & Hassan, Adel & Sudão & 12-dez-07 & Sudão \\
\hline 486 & $\begin{array}{l}\text { Mahjoub, Muhammed al Ghazali } \\
\text { Babaker }\end{array}$ & Sudão & 31-mar-04 & Sudão \\
\hline 487 & $\begin{array}{l}\text { Raheem, al Rachid Hasan Ahmad } \\
\text { Abdul }\end{array}$ & Sudão & 31-mar-04 & Sudão \\
\hline 488 & Ghezali, Mehdi Mohammad & Suecia & 6-jul-04 & Suecia \\
\hline 489 & al Henali, Menhal & Síria & 31-mar-04 & - \\
\hline
\end{tabular}




\begin{tabular}{|c|c|c|c|c|}
\hline \multicolumn{5}{|c|}{$\begin{array}{l}\text { Prisioneiros transferidos da Prisão de Guantánamo (Cuba) para outros países. } \\
\text { (Até 01 de Junho de 2009) }\end{array}$} \\
\hline $\mathbf{N}^{\mathbf{o}}$ & Nome & Naciolidade & $\begin{array}{c}\text { Data da } \\
\text { Transfer. }\end{array}$ & Transferido para \\
\hline 490 & Fazrollah, Mehrabanb & Tajiquistão & 28-fev-07 & Tajiquistão \\
\hline 491 & Ghafar Homarovich, Shirinov & Tajiquistão & 31-mar-04 & Tajiquistão \\
\hline 492 & Homaro, Moyuballah & Tajiquistão & 31-mar-04 & Tajiquistão \\
\hline 493 & Irgashive, Abdul Karim & Tajiquistão & 17-jul-04 & Tajiquistão \\
\hline 494 & Mazharudin & Tajiquistão & 31-mar-04 & Tajiquistão \\
\hline 495 & Merozhev, Zainulabidin & Tajiquistão & 31-out-08 & Tajiquistão \\
\hline 496 & Nabied, Yusef & Tajiquistão & 17-jul-04 & Tajiquistão \\
\hline 497 & Sadee Eideov & Tajiquistão & 31-mar-04 & Tajiquistão \\
\hline 498 & Salehove, Maroof Saleemovich & Tajiquistão & 19-ago-05 & Tajiquistão \\
\hline 499 & Sharipov, Rukniddin Fayziddinovich & Tajiquistão & 28 -fev-07 & Tajiquistão \\
\hline 500 & Vakhidov, Sobit Valikhonovich & Tajiquistão & 28-fev-07 & - \\
\hline 501 & Bin Omar, Abdullah & Tunísia & 17-jun-07 & Tunísia \\
\hline 502 & Lagha, Lufti Bin Swei & Tunísia & 18-jun-07 & Tunísia \\
\hline 503 & Celik Gogus, Yuksel & Turquia & 18-nov-03 & Turquia \\
\hline 504 & Kurnaz, Murat & Turquia & 19-ago-05 & Alemanha \\
\hline 505 & Mart, Mahmud Nuri & Turquia & 31-mar-04 & Turquia \\
\hline 506 & Sen, Ibrahim Shafir & Turquia & 18-nov-03 & Turquia \\
\hline 507 & Uyar, Salih & Turquia & & Turquia \\
\hline 508 & Turkash, Emdash Abdullah & Turquemenistão & 31-mar-04 & - \\
\hline 509 & Kiyemba, Jamal Abdullah & Uganda & 7-fev-06 & Uganda \\
\hline 510 & Alhamiri, Abdulah & $\begin{array}{c}\text { Emirados } \\
\text { Arabes }\end{array}$ & 26-jul-08 & Emirados Arabes \\
\hline 511 & Abassi, Feroz Ali & Reino Unido & 25-jan-05 & Reino Unido \\
\hline 512 & Ahmed, Rhuhel ${ }^{190}$ & Reino Unido & 9-mar-04 & Reino Unido \\
\hline 513 & al Harith, Jamal Malik & Reino Unido & 9-mar-04 & Reino Unido \\
\hline 514 & Begg, Moazzam & Reino Unido & 26-jan-05 & Reino Unido \\
\hline 515 & Belmar, Richard Dean & Reino Unido & 27 -jan-05 & Reino Unido \\
\hline 516 & Iqbal, Asif $^{191}$ & Reino Unido & 9-mar-04 & Reino Unido \\
\hline 517 & Mubanga, Martin John & Reino Unido & 28-jan-05 & Reino Unido \\
\hline 518 & Rasul, Shafiq ${ }^{192}$ & Reino Unido & 9-mar-04 & Reino Unido \\
\hline 519 & Adam, Mohammed Sadiq & Uzbequistão & 14-mar-04 & - \\
\hline 520 & Asam, Zakirjan & $\begin{array}{l}\text { Uzbequistão, } \\
\text { Rússia }\end{array}$ & 17-nov-06 & Albania \\
\hline 521 & Hussein, Abdul Qadir Yousef & Cisjordânia & 31-mar-04 & - \\
\hline 522 & al Asadi, Mohammed Ahmed Ali & Iêmen & 15-dez-06 & Iêmen \\
\hline 523 & al Jayfi, Issam Hamid al Bin Ali & Iêmen & 21-dez-06 & Iêmen \\
\hline 524 & al Marwa'i, Toufiq Saber Muhammad & Iêmen & 15-dez-06 & Iêmen \\
\hline 525 & al Shulan, Hani Abdul Muslih & Iêmen & 18-jun-07 & Iêmen \\
\hline 526 & al Tays, Ali Husayn Abdullah & Iêmen & 15-dez-06 & Iêmen \\
\hline 528 & al Zuba, Saleh Mohamed & Iêmen & 15-dez-06 & Iêmen \\
\hline 529 & Hamdan, Salim Ahmed $^{193}$ & Iêmen & 25-nov-08 & Iêmen \\
\hline
\end{tabular}

${ }^{190}$ Aif Iqbal, Rhuhel Ahmed e Shafiq Rasul, ingleses que foram capturados no Afeganistão em 2001 e levados para Guantánamo como terroristas. Tiveram a sua história contada no filmedocumentário britânico Caminho para Guantanamo (The Road to Guantanamo), escrito e dirigido por Michael Winterbottom. O filme foi premiado com o Urso de Prata na categoria melhor diretor no Festival de Berlim de 2006. The Road to Guantanamo. Filme. Disponível em <http://www.roadtoguantanamomovie.com/>. Acesso em 10 mai. 2009.

${ }^{191}$ V. nota 165 acima.

${ }^{192}$ V. nota 165 acima. 


\begin{tabular}{|c|c|c|c|c|}
\hline \multicolumn{5}{|c|}{$\begin{array}{l}\text { Prisioneiros transferidos da Prisão de Guantánamo (Cuba) para outros países. } \\
\text { (Até } 01 \text { de Junho de 2009) }\end{array}$} \\
\hline $\mathbf{N}^{\mathbf{o}}$ & Nome & Naciolidade & $\begin{array}{l}\text { Data da } \\
\text { Transfer. }\end{array}$ & Transferido para \\
\hline 530 & Ismail, Sadeq Muhammad Said & Iêmen & 18-jun-07 & Iêmen \\
\hline 531 & Khamsan, Karam Khamis Sayd & Iêmen & 19-ago-05 & Iêmen \\
\hline 532 & $\begin{array}{l}\text { Mahdi, Fawaz Naman Hamoud } \\
\text { Abdullah }\end{array}$ & Iêmen & 18-jun-07 & Iêmen \\
\hline 533 & Moqbill, Muhsin Muhammad Musheen & Iêmen & 15-dez-06 & Iêmen \\
\hline 535 & Salih, Ali Mohsen & Iêmen & 18-jun-07 & Iêmen \\
\hline 536 & Shahir, Walid Mohammed & Iêmen & 31-mar-04 & Iêmen \\
\hline 537 & El Gharani, Mohammed & Chade & 11-jun-09* & Chade \\
\hline 539 & Abdulahat, Emam & China & 11-jun-09* & Bermudas \\
\hline 540 & Abdulqadirakhun, Abdullah & China & 11-jun-09* & Bermudas \\
\hline 541 & Mamut, Abdul Helil & China & 11-jun-09* & Bermudas \\
\hline 542 & Parhat, Hozaifa & China & 11-jun-09* & Bermudas \\
\hline 543 & Sadkhan, Jawad Jabber & Iraque & 10 -jun-09* & Iraque \\
\hline 544 & Ghailani, Ahmed Khalfan & Tanzania & 9-jun-09* & Estados Unidos \\
\hline
\end{tabular}

* Data prevista para a transferência

Fonte: The Guantánamo Docket, The New York Times, 2009.

Traduzido e adaptado por: Cintia Reschke de Borba

\section{Tabela 02}

\begin{tabular}{|c|c|c|c|}
\hline \multicolumn{4}{|c|}{$\begin{array}{l}\text { Prisioneiros remanescentes na Prisão de Guantánamo (Cuba) } \\
\text { (Até 01 de Junho de 2009) }\end{array}$} \\
\hline $\mathbf{N}^{\mathbf{0}}$ & Nome & Nacionalidade & Observações \\
\hline 1 & al Afghani, Haroon & Afeganistão & \\
\hline 2 & al Afghani, Muhammad Rahim & Afeganistão & \\
\hline 3 & Fazl, Mullah Mohammad & Afeganistão & \\
\hline 4 & Ghani, Abdul & Afeganistão & \\
\hline 5 & Gul, Awal & Afeganistão & \\
\hline 6 & Gul, Khi Ali & Afeganistão & \\
\hline 7 & Hafiz, Abdul & Afeganistão & \\
\hline 8 & Hamidullah & Afeganistão & \\
\hline 9 & Hashim, Mohammed & Afeganistão & \\
\hline 10 & Inayatullah & Afeganistão & \\
\hline 11 & Jawad, Mohamed & Afeganistão & \\
\hline 12 & Kamin, Mohammed & Afeganistão & \\
\hline 13 & Karim, Bostan & Afeganistão & \\
\hline 14 & Khairkhwa, Khirullah Said Wali & Afeganistão & \\
\hline
\end{tabular}

${ }^{193}$ Salim Ahmed Hamdan, ex-motorista de Osama bin Laden, foi condenado, em 7 de agosto de 2008, a 66 meses (5 anos e meio) de prisão pelo crime de "apoio material ao terrorismo". Foi julgado por um Tribunal Militar americano de Guantánamo, o promotor havia pedido uma pena "de no mínimo" 30 anos. Foi o primeiro julgamento por crimes de guerra realizado por um tribunal militar norte-americano desde o final da Segunda Guerra Mundial. FRANCE PRESSE. Tribunal de Guantánamo condena motorista de Bin Laden a 5,5 anos. G1 Globo, 07 ago. 2008. Disponível em <http://g1.globo.com/Noticias/Mundo/0,,MUL7156885602,00TRIBUNAL+DE+GUANTÁNAMO+CONDENA+MOTORISTA+DE+BIN+LADEN+A +ANOS.html>. Acesso em 15 abr. 2009. 


\begin{tabular}{|c|c|c|c|}
\hline \multicolumn{4}{|c|}{$\begin{array}{l}\text { Prisioneiros remanescentes na Prisão de Guantánamo (Cuba) } \\
\text { (Até 01 de Junho de 2009) }\end{array}$} \\
\hline $\mathbf{N}^{\mathbf{o}}$ & Nome & Nacionalidade & Observações \\
\hline 15 & Khan, Shawali & Afeganistão & \\
\hline 16 & Mohammed, Haji Wali & Afeganistão & \\
\hline 17 & Noori, Mullah Norullah & Afeganistão & \\
\hline 18 & Obaidullah & Afeganistão & \\
\hline 19 & Omari, Mohammad Nabi & Afeganistão & \\
\hline 20 & Rahim, Mohamed & Afeganistão & \\
\hline 21 & Sharifullah & Afeganistão & \\
\hline 22 & Sohail, Mohammed Mustafa & Afeganistão & \\
\hline 23 & Wasiq, Abdul Haq & Afeganistão & \\
\hline 24 & Zahir, Abdul & Afeganistão & \\
\hline 25 & Zahir, Mohommod & Afeganistão & \\
\hline 26 & Abdelrahman, Abdelrazak Ali & Algéria & \\
\hline 27 & Ameziane, Djamel Saiid Ali & Algéria & \\
\hline 28 & Barhoumi, Sufyian & Algéria & \\
\hline 29 & Bel Bacha, Ahmed Bin Saleh & Algéria & \\
\hline 30 & Belkacem, Bensayah & Algéria & \\
\hline 31 & Bin Hamlili, Adil Hadi al Jazairi & Algéria & \\
\hline 32 & Farhi, Saiid & Algéria & \\
\hline 33 & Hadjarab, Nabil & Algéria & \\
\hline 34 & Lahmar, Sabir Mahfouz & Algéria & \\
\hline 35 & Naji, Aziz Abdul & Algéria & \\
\hline 36 & Sayab, Mutij Sadiz Ahmad & Algéria & \\
\hline 37 & Zumiri, Hassan & Algéria & \\
\hline 38 & Aamer, Shaker & Arábia Saudita & \\
\hline 39 & al Bedani, Abdul Khaled Ahmed Sahleh & Arábia Saudita & \\
\hline 40 & al Bihani, Tolfiq Nassar Ahmed & Arábia Saudita & \\
\hline 41 & al Darbi, Ahmed Muhammed Haza & Arábia Saudita & \\
\hline 42 & al Hawsawi, Mustafa Ahmed & Arábia Saudita & \\
\hline 43 & al Nashiri, Abd al Rahim & Arábia Saudita & \\
\hline 44 & al Qahtani, Jabran Said Wazar & Arábia Saudita & \\
\hline 45 & al Qahtani, Mohammed & Arábia Saudita & \\
\hline 46 & Qahtani, Said Muhammad Husyan & Arábia Saudita & \\
\hline 47 & Shalabi, Abdul Rahman & Arábia Saudita & \\
\hline 48 & al Sharbi, Ghassan Abdullah & Arábia Saudita & \\
\hline 49 & al Shumrani, Mohammad al Rahman & Arábia Saudita & \\
\hline 50 & al Shurfa, Ohmed Ahmed Mahamoud & Arábia Saudita & \\
\hline 51 & al Zabe, Slah Muhamed Salih & Arábia Saudita & \\
\hline 52 & al Zahrani, Muhammed Murdi Issa & Arábia Saudita & \\
\hline 53 & Tsiradzho, Poolad T & Azerbaijão & \\
\hline 54 & Khadr, Omar Ahmed ${ }^{194}$ & Canada & \\
\hline 55 & Abbas, Yusef & China & \\
\hline
\end{tabular}

${ }^{194}$ Omar khadr, canadense, foi preso no Afeganistão em 2002, quando tinha apenas 15 anos, com a alegaçao de ter causado a morte a um soldado norte-americano durante um combate. Teve julgamento paralizado em funçao das novas determinaçoes do Pres. Obama. O ESTADÃO. A pedido de Obama, Justiça congela $1^{\circ}$ processo de Guantánamo. O Estadão Internacional, 21 jan. 2009. Disponível em <http://www.estadao.com.br/noticias/internacional,a-pedido-de-obamajustica-congela-1-processo-de-Guantánamo,310640,0.htm>. Acesso em 15 abr. 2009. 


\begin{tabular}{|c|c|c|c|}
\hline \multicolumn{4}{|c|}{$\begin{array}{l}\text { Prisioneiros remanescentes na Prisão de Guantánamo (Cuba) } \\
\text { (Até 01 de Junho de 2009) }\end{array}$} \\
\hline $\mathbf{N}^{\circ}$ & Nome & Nacionalidade & Observações \\
\hline 56 & Abdul Rahman, Abdul Ghappar & China & \\
\hline 57 & Abdulghupur, Hajiakbar & China & \\
\hline 58 & Abdurehim, Dawut & China & \\
\hline 59 & Anvar, Hassan & China & \\
\hline 60 & Khalik, Saidullah & China & \\
\hline 61 & Mahmud, Arkin & China & \\
\hline 62 & Mahnut, Bahtiyar & China & \\
\hline 63 & Mohamed, Ahmed & China & \\
\hline 64 & Mohammed, Nag & China & \\
\hline 65 & Noori, Adel & China & \\
\hline 66 & Razak, Abdul & China & \\
\hline 67 & Tourson, Ahmad & China & \\
\hline 68 & al Quwari, Mahrar Rafat & Cisjordânia & \\
\hline 69 & Tahamuttan, Mohammed Abdullah & Cisjordânia & \\
\hline 70 & Algazzar, Adel Fattough Ali & Egito & \\
\hline 71 & al Mishad, Sharif Fati Ali & Egito & \\
\hline 72 & al Sawah, Tariq Mahmoud Ahmed & $\begin{array}{l}\text { Egito, Bósnia e } \\
\text { Herzegovina }\end{array}$ & \\
\hline 73 & $\begin{array}{l}\text { Abd al Sattar, Muieen A Deen Jamal A } \\
\text { Deen Abd al Fusal }\end{array}$ & Emirados Árabes & \\
\hline 74 & Abd al Mujahid, Mahmoud Abd al Aziz & Iêmen & \\
\hline 75 & Abd al Rahman, Allal Ab Aljallil & Iêmen & \\
\hline 76 & Abd al Wahab, Abd al Malik & Iêmen & \\
\hline 77 & Abu Ghanim, Mohammed Rajab Sadiq & Iêmen & \\
\hline 78 & Adayn, Omar Said Salem & Iêmen & \\
\hline 79 & Ahmad, Majid Mahmud Abdu & Iêmen & \\
\hline 80 & Ahmed, Abdul Rahman & Iêmen & \\
\hline 81 & Ahmed, Fahmi Abdullah & Iêmen & \\
\hline 82 & Ahmed, Fayad Yahya & Iêmen & \\
\hline 83 & Ahmed, Faruq Ali & Iêmen & \\
\hline 84 & Alahdal, Abu Bakr Ibn Ali Muhhammad & Iêmen & \\
\hline 85 & al Alwi, Moath Hamza Ahmed & Iêmen & \\
\hline 86 & Aleh, Ali Bin Ali & Iêmen & \\
\hline 87 & al Ansi, Muhammad Ahmad Abdallah & Iêmen & \\
\hline 88 & Awad, Jalal Salam Awad & Iêmen & \\
\hline 89 & Awad, Waqas Mohammed Ali & Iêmen & \\
\hline 90 & Azani, Saad Masir Mukbl Al & Iêmen & \\
\hline 91 & Baada, Tarek Ali Abdullah Ahmed & Iêmen & \\
\hline 92 & al Bahlul, Ali Hamza Ahmad Suliman & Iêmen & \\
\hline 93 & Basardah, Yasim Muhammed & Iêmen & \\
\hline 94 & Batarfi, Ayman Saeed Abdullah & Iêmen & \\
\hline 95 & al Bihani, Ghaleb Nassar & Iêmen & \\
\hline 96 & Bin al Shibh, Ramzi & Iêmen & \\
\hline 97 & Bin Atef, Mahmmoud Omar Mohammed & Iêmen & \\
\hline 98 & Bin Attash, Hassan Mohammed Ali & Iêmen & \\
\hline 99 & Bin Attash, Walid & Iêmen & \\
\hline 100 & Bin Hamdoun, Zahar Omar Hamis & Iêmen & \\
\hline 101 & Bin Salem, Muhhammad Said & Iêmen & \\
\hline
\end{tabular}




\begin{tabular}{|c|c|c|c|}
\hline \multicolumn{4}{|c|}{$\begin{array}{l}\text { Prisioneiros remanescentes na Prisão de Guantánamo (Cuba) } \\
\text { (Até 01 de Junho de 2009) }\end{array}$} \\
\hline $\mathbf{N}^{\mathbf{o}}$ & Nome & Nacionalidade & Observações \\
\hline 102 & al Busayss, Adil Said al Haj Obeid & Iêmen & \\
\hline 103 & Bwazir, Mohammed Ali Abdullah & Iêmen & \\
\hline 104 & Balzuhair, Shawki Awad & Iêmen & \\
\hline 105 & al Dhuby, Khalid Mohammed Salih & Iêmen & \\
\hline 106 & al Edah, Mohammed Ahmad Said & Iêmen & \\
\hline 107 & Ghazi, Fahed Abdullah Ahmad & Iêmen & \\
\hline 108 & Hadi, Salem Ahmed & Iêmen & \\
\hline 109 & Haidel, Mohammed Ahmed Said & Iêmen & \\
\hline 107 & Hakim, Abdel Ghalib Ahmad & Iêmen & \\
\hline 108 & al Hamiri, Mohammed Abdullah & Iêmen & \\
\hline 109 & Hassan, Emad Abdalla & Iêmen & \\
\hline 110 & Hassen, Mohammed Mohammed & Iêmen & \\
\hline 111 & Hatim, Said Muhammed Salih & Iêmen & \\
\hline 112 & al Hikimi, Ahmed Umar Abdullah & Iêmen & \\
\hline 113 & al Hilal, Abdul al Salam & Iêmen & \\
\hline 114 & Hintif, Fadil Husayn Salih & Iêmen & \\
\hline 115 & Ismail, Yasin Qasem Muhammad & Iêmen & \\
\hline 116 & $\begin{array}{l}\text { Jarabh, Saeed Ahmed Mohammed Abdullah } \\
\text { Sarem }\end{array}$ & Iêmen & \\
\hline 117 & al Kazimi, Sanad Yislam & Iêmen & \\
\hline 118 & al Khalaqi, Asim Thahit Abdullah & Iêmen & \\
\hline 119 & Khnenah, Muhammed Ali Hussein & Iêmen & \\
\hline 120 & Khusruf, Mohammed Nasir Yahya & Iêmen & \\
\hline 121 & al Madoonee, Musab Omar Ali & Iêmen & \\
\hline 122 & Mari, Jamal Muhammed Alawi & Iêmen & \\
\hline 123 & al Marwalah, Bashir Nasir Ali & Iêmen & \\
\hline 124 & Masud, Sharaf Ahmad Muhammad & Iêmen & \\
\hline 125 & al Maythal, Hail Aziz Ahmad & Iêmen & \\
\hline 126 & Mohammed, Hussein Salem & Iêmen & \\
\hline 127 & Moqbel, Samir Naji al Hasan & Iêmen & \\
\hline 128 & al Mudhaffari, Abdel Qadir Hussein & Iêmen & \\
\hline 129 & Muhammad, Abd al Rahman Abdullah Ali & Iêmen & \\
\hline 130 & $\begin{array}{l}\text { al Nahdi, Sulaiman Awath Sulaiman Bin } \\
\text { Ageel }\end{array}$ & Iêmen & \\
\hline 131 & Nashir, Said Salih Said & Iêmen & \\
\hline 132 & Nassir, Jamil Ahmed Said & Iêmen & \\
\hline 133 & $\begin{array}{l}\text { al Qadasi, Khalid Abd Jal Jabbar } \\
\text { Muhammad Juthman }\end{array}$ & Iêmen & \\
\hline 134 & Qader, Ahmed Abdul & Iêmen & \\
\hline 135 & Qader Idris, Idris Ahmed Abdu & Iêmen & \\
\hline 136 & Qasim, Khaled & Iêmen & \\
\hline 137 & Qattaa, Mansoor Muhammed Ali & Iêmen & \\
\hline 138 & al Qurashi, Sabri Mohammed Ebrahim & Iêmen & \\
\hline 139 & Qyati, Abdul Rahman Umir Al & Iêmen & \\
\hline 140 & Rabeii, Salman Yahya Hassan Mohammed & Iêmen & \\
\hline 141 & al Radai, Riyad Atiq Ali Abdu al Haj & Iêmen & \\
\hline 142 & al Rahizi, Ali Ahmad Muhammad & Iêmen & \\
\hline 143 & al Raimi, Ali Yahya Mahdi & Iêmen & \\
\hline
\end{tabular}




\begin{tabular}{|c|c|c|c|}
\hline \multicolumn{4}{|c|}{$\begin{array}{l}\text { Prisioneiros remanescentes na Prisão de Guantánamo (Cuba) } \\
\text { (Até 01 de Junho de 2009) }\end{array}$} \\
\hline $\mathbf{N}^{\mathbf{o}}$ & Nome & Nacionalidade & Observações \\
\hline 144 & al Rammah, Omar Mohammed Ali & Iêmen & \\
\hline 145 & al Sabri, Mashur Abdallah Muqbil Ahmed & Iêmen & \\
\hline 146 & Said Kuman, Ahmed Yaslam & Iêmen & \\
\hline 147 & Salam, Mohammed Ahmed & Iêmen & \\
\hline 148 & al Sani, Fahmi Salem Said & Iêmen & \\
\hline 149 & al Saleh, Abdul & Iêmen & \\
\hline 150 & Saleh, Ayoub Murshid Ali & Iêmen & \\
\hline 151 & Saleh Naser, Abdul Rahman Mohamed & Iêmen & \\
\hline 152 & Salem al Zarnuki, Mohammed Ali & Iêmen & \\
\hline 153 & al Shabli, Abdullah Yahia Yousf & Iêmen & \\
\hline 154 & $\begin{array}{l}\text { al Shamyri, Mustafa Abdul Qawi Abdul } \\
\text { Aziz }\end{array}$ & Iêmen & \\
\hline 155 & al Sharabi, Zuhail Abdo Anam Said & Iêmen & \\
\hline 156 & Sharqawi, Abdu Ali al Haji & Iêmen & \\
\hline 157 & Salih, Abdul al Razzaq Muhammad & Iêmen & \\
\hline 158 & al Suadi, Abdul Aziz Abdullah Ali & Iêmen & \\
\hline 159 & $\begin{array}{l}\text { Sulayman, Abdul Rahman Abdul Abu } \\
\text { Ghityh }\end{array}$ & Iêmen & \\
\hline 160 & Suleiman, Fayiz Ahmad Yahia & Iêmen & \\
\hline 161 & Tahar, Mohmmad Ahmad Ali & Iêmen & \\
\hline 162 & Uthman, Uthman Abdul Rahim Mohammed & Iêmen & \\
\hline 163 & $\begin{array}{l}\text { al Wady, Hamoud Abdullah Hamoud } \\
\text { Hassan }\end{array}$ & Iêmen & \\
\hline 164 & al Warafi, Muktar Yahya Najee & Iêmen & \\
\hline 165 & al Yafi, al Khadr Abdallah Muhammed & Iêmen & \\
\hline 166 & Zaid, Walid Said Bin Said & Iêmen & \\
\hline 167 & Hambali (Riduan Isamuddin) & Indonésia & \\
\hline 168 & al Iraqi, Abd al Hadi & Iraque & \\
\hline 169 & Malik, Abdul & Quênia & \\
\hline 170 & al Awda, Fouzi Khalid Abdullah & Kuwait & \\
\hline 171 & al Kandari, Faiz Mohammed Ahmed & Kuwait & \\
\hline 172 & al Mutayri, Khalid Abdullah Mishal Thamer & Kuwait & \\
\hline 173 & al Rabia, Fouad Mahoud Hasan & Kuwait & \\
\hline 174 & Abu Bakr, Omar Khalifa Mohammed & Líbia & \\
\hline 175 & $\begin{array}{l}\text { Abu al Qusin, Abdul Rauf Omar } \\
\text { Mohammed }\end{array}$ & Líbia & \\
\hline 176 & al Bakush, Ismael Ali Farag & Líbia & \\
\hline 177 & $\begin{array}{l}\text { al Ghazzawi, Abdel Hamid Ibn Abdussalem } \\
\text { Ibn Miftah }\end{array}$ & Líbia & \\
\hline 178 & Ghereby, Salem Abdul Salem & Líbia & \\
\hline 179 & al Libbi, Abu Faraj & Líbia & \\
\hline 180 & Sultan, Ashraf Salim Abd al Salam & Líbia & \\
\hline 181 & Lillie (Mohammed Nazir Bin Lep) & Malásia & \\
\hline 182 & Zubair (Mohd Farik Bin Amin) & Malásia & \\
\hline 185 & Nasir, Abdul Latif & Marrocos & \\
\hline 186 & Shokuri, Yunis Abdurrahman & Marrocos & \\
\hline 183 & Aziz, Ahamed Abdel & Mauritânia & \\
\hline 184 & Slahi, Mohamedou Ould & Mauritânia & \\
\hline
\end{tabular}




\begin{tabular}{|c|c|c|c|}
\hline \multicolumn{4}{|c|}{$\begin{array}{l}\text { Prisioneiros remanescentes na Prisão de Guantánamo (Cuba) } \\
\text { (Até 01 de Junho de 2009) }\end{array}$} \\
\hline $\mathbf{N}^{\mathbf{0}}$ & Nome & Nacionalidade & Observações \\
\hline 187 & Abu Rahman, Abdul Rabbani Abd al Rahim & Paquistão & \\
\hline 188 & Ali, Abd al Aziz & Paquistão & \\
\hline 189 & Khan, Majid & Paquistão & \\
\hline 190 & Mohammed, Khalid Shaikh & Paquistão & \\
\hline 191 & Paracha, Saifullah & Paquistão & \\
\hline 192 & Rabbani, Mohammed Ahmad Ghulam & Paquistão & \\
\hline 193 & Zubaydah, Abu & Palestina & \\
\hline 194 & al Aasmi, Assem Matruq Mohammad & $\begin{array}{l}\text { Palestina, Arábia } \\
\text { Saudita }\end{array}$ & \\
\hline 195 & Mingazov, Ravil & Rússia & \\
\hline 202 & Ahjam, Ahmed Adnan & Síria & \\
\hline 203 & $\begin{array}{l}\text { al Ali, Mahmud Salem Horan Mohammed } \\
\text { Mutlak }\end{array}$ & Síria & \\
\hline 204 & Diyab, Jihad Ahmed Mujstafa & Síria & \\
\hline 205 & Dokhan, Moammar Badawi & Síria & \\
\hline 206 & Faraj, Abd al Hadi Omar Mahmoud & Síria & \\
\hline 207 & Janko, Abd al Rahim Abdul Rassak & Síria & \\
\hline 208 & $\begin{array}{l}\text { Khantumani, Abd al Nasir Mohammed Abd } \\
\text { al Qadir }\end{array}$ & Síria & \\
\hline 209 & $\begin{array}{l}\text { Khantumani, Muhammad Abd al Nasir } \\
\text { Muhammad }\end{array}$ & Síria & \\
\hline 210 & Mouhammad, Maasoum Abdah & Síria & \\
\hline 211 & Shaaban, Ali Husein & Síria & \\
\hline 196 & Arale, Abdullahi Sudi & Somália & \\
\hline 197 & Barre, Mohammed Sulaymon & Somália & \\
\hline 198 & Dourad, Gouled Hassan & Somália & \\
\hline 199 & Idris, Ibrahim Othman Ibrahim & Sudão & \\
\hline 200 & Muhammed, Noor Uthman & Sudão & \\
\hline 201 & al Qosi, Ibrahim Ahmed Mahmoud & Sudão & \\
\hline 212 & Abdulayev, Omar Hamzayavich & Tajiquistão & \\
\hline 215 & Abdallah, Sayf Bin & Tunísia & \\
\hline 216 & Bin Ali, Lotfi & Tunísia & \\
\hline 217 & Bin Hadiddi, Abdul Haddi & Tunísia & \\
\hline 218 & Bin Hamida, Adil Mabrouk & Tunísia & \\
\hline 219 & al Hami, Rafiq Bin Bashir Bin Jalud & Tunísia & \\
\hline 220 & Hkiml, Adel Bin Ahmed Bin Ibrahim & Tunísia & \\
\hline 221 & Nasseri, Riyad Bil Mohammmed Tahir & Tunísia & \\
\hline 222 & Ourgy, Abdul Bin Mohammed Bin Abess & Tunísia & \\
\hline 223 & Sliti, Hisham Bin Ali Bin Amor & Tunísia & \\
\hline 225 & al Yazidi, Ridah Bin Saleh & Tunísia & \\
\hline 226 & Hamidullah, Ali Sher & Uzebequistão & \\
\hline 227 & Hamiduva, Shakhrukh & Uzebequistão & \\
\hline 228 & Jamaludinovich, Abu Bakir & Uzebequistão & \\
\hline 229 & Kasimbekov, Kamalludin & Uzebequistão & \\
\hline
\end{tabular}




\section{Tabela 03}

\begin{tabular}{|c|c|c|c|}
\hline \multicolumn{4}{|c|}{$\begin{array}{l}\text { Prisioneiros mortos na prisão de Guantánamo } \\
2002 \text { até } 01 \text { de junho de } 2009\end{array}$} \\
\hline $\mathbf{N}^{\mathbf{o}}$ & Nome & Data da morte & Observações \\
\hline 1 & Ahmed, Ali Abdullah & 10-jun-06 & $\begin{array}{l}\text { Suicídio por } \\
\text { enforcamento }\end{array}$ \\
\hline 2 & al Amri, Abdul Rahman Ma'ath Thafir & 30-mai-07 & Suicídio \\
\hline 3 & $\begin{array}{l}\text { al Hanashi, Mohammad Ahmed Abdullah } \\
\text { Saleh }\end{array}$ & 1-jun-09 & Suicídio \\
\hline 4 & al Tabi, Mana Shaman Allabardi & 10-jun-06 & $\begin{array}{l}\text { Suicídio por } \\
\text { enforcamento }\end{array}$ \\
\hline 5 & al Zahrani, Yasser Talal & 10-jun-06 & $\begin{array}{l}\text { Suicídio por } \\
\text { enforcamento }\end{array}$ \\
\hline 6 & Hekmati, Abdul Razzaq & 30-dez-07 & Suicídio \\
\hline
\end{tabular}


102

Pontificia Univemsidade Católica Do RIO DE JANEIHo

NORMAS PARA ELABORAÇĀO E APRESENTAÇÃO DA MONOGRAFIA IUR 1919

ANEXO II

A Monogralia deve ser entregue até o dia 4 de junho de 2009.

A presente Monografia. poderá ser submetida à exposiçẫo e defesia perante a Banca Examinadara designada pelo Departamento de Direito da PUC.Rio,

Rio de Janeiro. 4 de gunhode 2009

JWAO RICARDO DBRWELES

Nome do(a) professoria) oricetador(a)

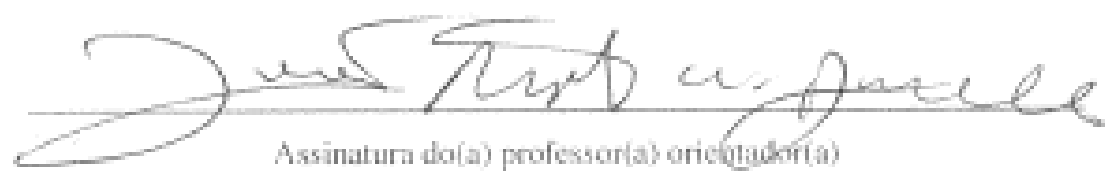

O(A) autor(a) deste trabalho autoriza o Departamento de Direito da PUC-Rio a divalgálo, no $10 d$ ou em parte, resguardados os direilos autorais conforme legislacho vigente.

Rio de Janeiro 4 de fun hoovo9.

- Eintia R.dl Borba

Axsinatura do(a) aluno(a) 